University of Texas at El Paso

ScholarWorks@UTEP

Open Access Theses \& Dissertations

2020-01-01

\title{
Application of Non-Seismic Methods to Analyze and Model the Geometry of the Northern Margin of the Onion Creek Salt Diapir, Paradox Basin, Utah
}

Julia Michelle Astromovich

University of Texas at El Paso

Follow this and additional works at: https://scholarworks.utep.edu/open_etd

Part of the Geophysics and Seismology Commons

\section{Recommended Citation}

Astromovich, Julia Michelle, "Application of Non-Seismic Methods to Analyze and Model the Geometry of the Northern Margin of the Onion Creek Salt Diapir, Paradox Basin, Utah" (2020). Open Access Theses \& Dissertations. 3141.

https://scholarworks.utep.edu/open_etd/3141

This is brought to you for free and open access by ScholarWorks@UTEP. It has been accepted for inclusion in Open Access Theses \& Dissertations by an authorized administrator of ScholarWorks@UTEP. For more information, please contact Iweber@utep.edu. 


\title{
APPLICATION OF NON-SEISMIC METHODS TO ANALYZE AND MODEL THE GEOMETRY OF THE NORTHERN MARGIN OF THE ONION CREEK \\ SALT DIAPIR, PARADOX BASIN, UTAH
}

\author{
JULIA MICHELLE ASTROMOVICH \\ Master's Program in Geophysics
}

APPROVED:

Diane Doser, Ph.D., Chair

Katherine Giles, Ph.D.

William Houston, Ph.D.

Stephen L. Crites, Jr., Ph.D.

Dean of the Graduate School 
Copyright (C)

by

Julia Astromovich

2020 


\section{DEDICATION}

I would like to dedicate this thesis to my family, mentors, and teachers who have helped me get here. I stand on the shoulders of giants and could not have done this without their encouragement. To my parents Kim and Michael and my brother Andrew, thank you for standing behind all that I do and encouraging my love and curiosity for the sciences at a young age. I would also like to thank my grandparents and aunts for the support and attending my virtual defense. To have the whole family behind me meant the world. I would also like to dedicate this thesis to my teachers from kindergarten all the way to my graduate years. These individuals taught me the skills I needed to succeed from reading and writing at a young age, to artistic skill to create my many figures, to how to write an academic paper, and the geoscience skills I enjoyed learning the most. I would also like dedicate this thesis to my undergraduate mentor, Paul Kelso. In Paul's words I learned geology by doing geology and I will forever be thankful for the field experience and mentorship I received at Lake Superior State University. Also, a big thank you to Bill Houston for helping me develop my profession skills and always being just a phone call away to keep my mental health in check. Where Paul gave me my love for field work and geophysics, Bill bestowed upon me my passion for the challenges of the oil and gas industry and sedimentology. Lastly, I would like to dedicate this thesis to my current advisor, Diane Doser, who is one of the best teachers I have ever had with the right balance of challenge and knowledge packed into her courses. With all of these folks behind me and cheering me on, I would like a moment to thank them and dedicate this thesis to them. 


\section{APPLICATION OF NON-SEISMIC METHODS TO ANALYZE AND MODEL THE GEOMETRY OF THE NORTHERN MARGIN OF THE ONION CREEK \\ SALT DIAPIR, PARADOX BASIN, UTAH}

by

JULIA MICHELLE ASTROMOVICH, B.S

\section{THESIS}
Presented to the Faculty of the Graduate School of
The University of Texas at El Paso
in Partial Fulfillment
of the Requirements
for the Degree of

MASTER OF SCIENCE

Department of Geological Sciences

THE UNIVERSITY OF TEXAS AT EL PASO

December 2020 


\section{ACKNOWLEDGEMENTS}

First, I would like to acknowledge Mark Baker for his coding and processing work that makes up the bulk of the results of this thesis work. By developing this new software, this is a better way to model gravity and magnetic datasets for forward and inverse modeling. Learning a new coding language was far outside the scope of my project and the amount of time I had as a Masters student. This work would not have been possible without his help in developing this software. I would also like to thank Galen Kaip for initial training on the needed geophysical equipment and GPS. He also assisted with GPS processing and running smaller local surveys to make sure I was ready to perform these types of surveys far from UTEP and on my own. Thank you to Nila Matsler for helping with the paperwork process for travel and reimbursement, I don't know what I would have done without your help. A big thank you to each of my field assistants, Alondra Soltero, Michael Potter, and Rafael Ramos-Michael. I often expect a lot out of my field assistants with the number of hours it takes to run a survey, dealing with less than ideal weather, how heavy the equipment can become over time, and camping out in remote locations. Thank you to each of my peers within both of my research groups for survey design, data sharing, and bouncing ideas off of each other. Each of you was a pleasure to work with and I had the best time camping out at Onion Creek with each of you. I would also like to acknowledge the Institute of Tectonic Studies (ITS) group for sponsoring a number of my trips to the field. Lastly, I would like to thank the societies who awarded me scholarships and grants to make this thesis possible. These include the SEG student scholarships, AAPG graduate student research grant, AAPG southwest section scholarship, UTEP McBride Fellowship, Roswell Geologic Society Scholarship, and the Four Corners Geologic Society Scholarship. Lastly, I would like to thank the BP Mad Dog Reservoir Management Team

for helping to develop my professional skills as a geophysicist with my summer internship project. 


\begin{abstract}
The Onion Creek salt diapir lies within the Paradox Basin of Utah where it forms part of a series of salt walls that separate the Paradox Basin into smaller sub-basins. These sub-basins and associated salt diapirs remain key to several oil and gas traps in the region. A series of anomalous tight folds occur on the northern side of the Onion Creek diapir within the Permian Cutler Group Undifferentiated. These folds are thought to be associated with a shallow detachment horizon with three possible origins:1) a weak shale layer within the Cutler Group, 2) a salt shoulder, or 3) a salt namakier. I use gravity and magnetics methods to better determine the extent and geometry of the Onion Creek salt body in order to constrain the origin of the detachment horizon. Since the salt is less dense than the Cutler Group siliciclastics, gravity methods are some of the best at defining the extent of salt in the subsurface, while magnetic methods help delineate the more highly magnetic Cutler siliciclastics. Gravity data collected shows a low gravity anomaly over the diapir and then a gradual increase in gravity readings as more of the Cutler Group covers the subsurface salt. Magnetic data display a similar trend with a low over the diapir with values that generally increase with more Cutler sediment cover. By modeling these data in 2D with a newly developed software, a best-fit model can be chosen for the concealed salt structure on the northern margin at Onion Creek. This modeling process indicated a salt shoulder model best fit the geophysical data. These results suggest gravity and magnetic methods are a low-cost alternative to seismic surveys to evaluate what subsurface salt structure can be present for oil and gas exploration studies. Knowing these salt geometries are key to developing a safe, effective, and high-recovery drilling plan.
\end{abstract}




\section{TABLE OF CONTENTS}

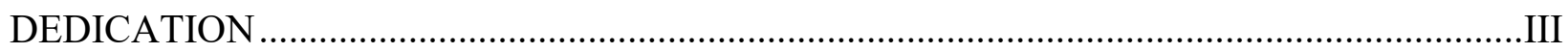

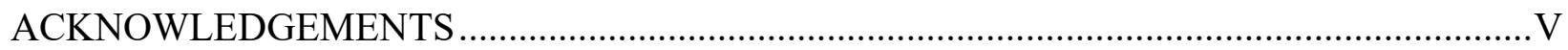

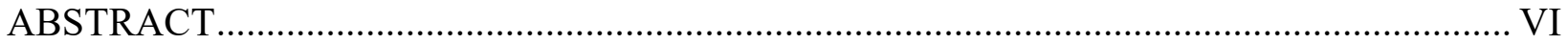

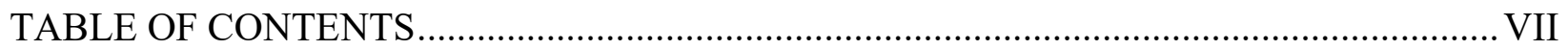

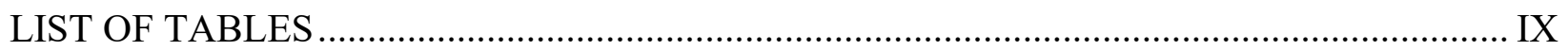

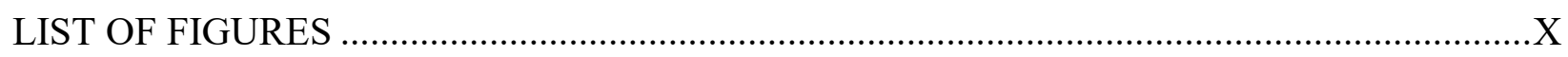

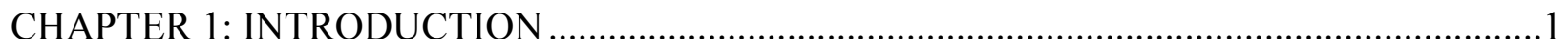

CHAPTER 2: GEOLOGIC SETTING AND PREVIOUS STUDIES …………………..............

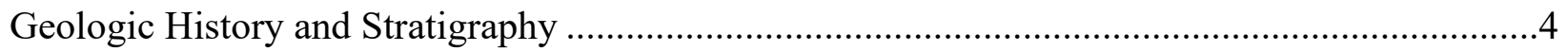

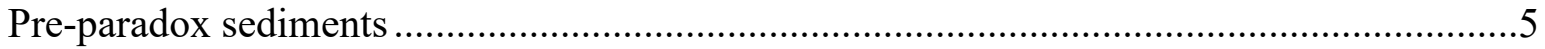

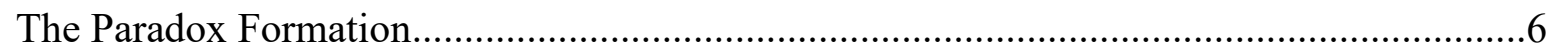

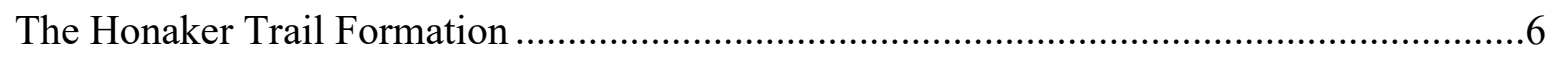

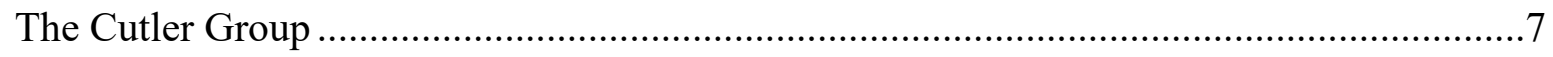

Quaternary Deposits....................................................................................................

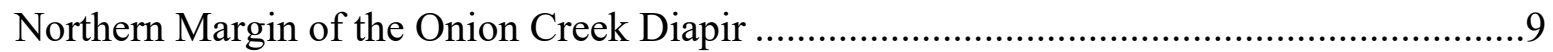

Geophysical Studies............................................................................................

Paradox Basin Hydrocarbons: Andy's Mesa and Double Eagle ..................................................10

The Mississippi Basin and Gulf Coast: Hydrocarbons Related to Salt Tectonism................13

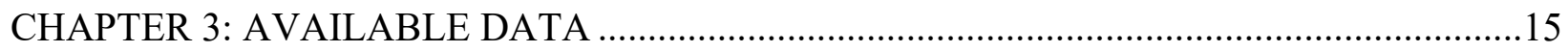

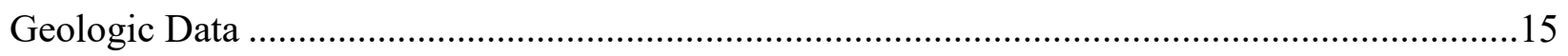

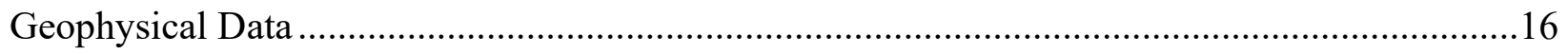

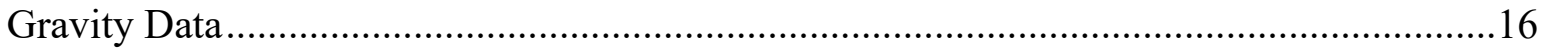

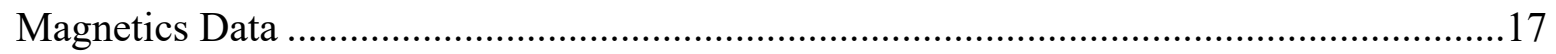




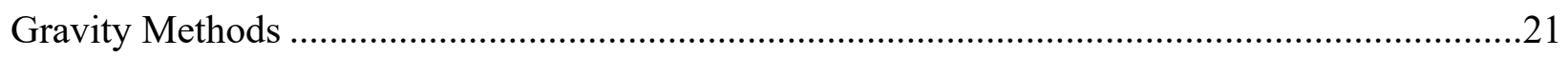

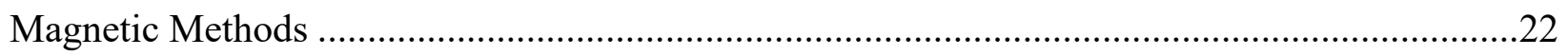

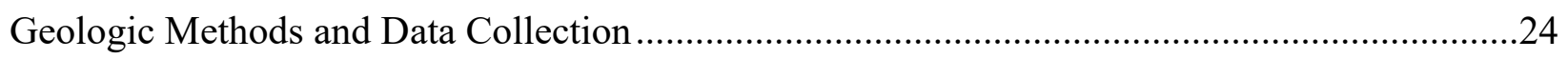

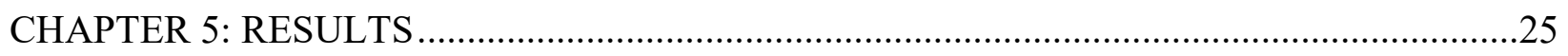

Initial Results and Older Software Models .......................................................................25

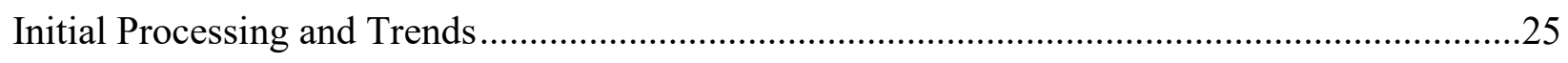

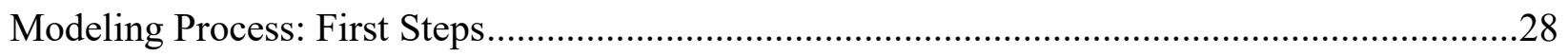

New Software: Gravity2DSurf and Magnetic2DSurf, DemGeoElev and DrawSection,

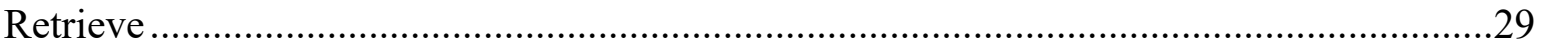

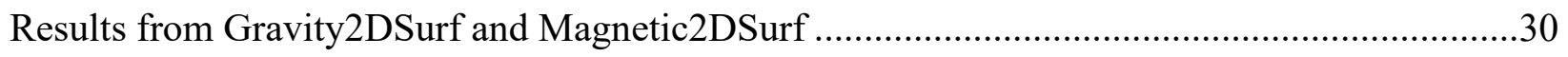

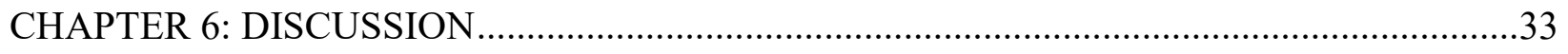

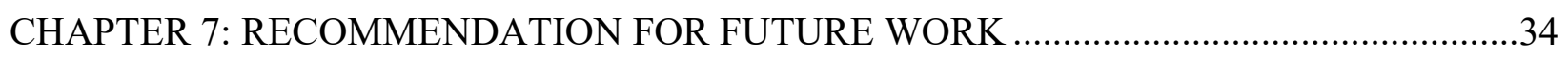

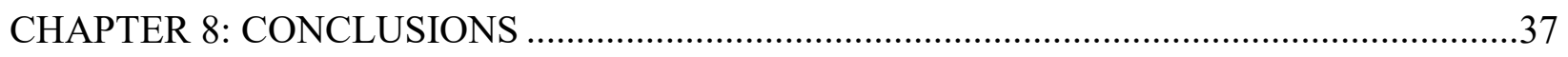

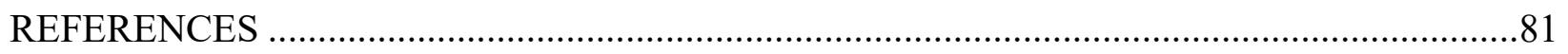

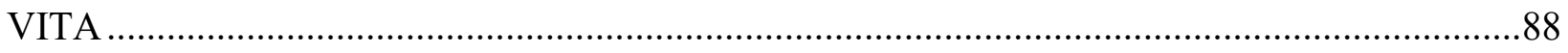




\section{LIST OF TABLES}

Table 1: Paradox and Cutler Density and Magnetic Suceptibility........................................... 38

Table 2: S2 Magnetic Susceptibility Forward Model....................................................... 39

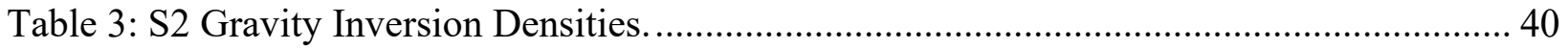

Table 4: S2 Magnetic Susceptibility Forward Model.......................................................... 41

Table 5: S2 Magnetic Susceptibility Inversions. ......................................................... 42

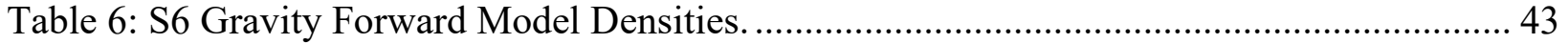

Table 7: S6 Gravity Inversion Densities........................................................................ 44 


\section{LIST OF FIGURES}

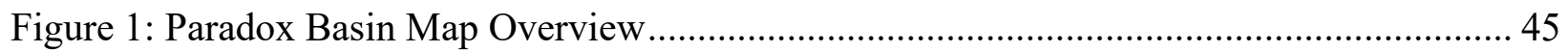

Figure 2: Onion Creek Area Geologic Map and Satellite View ……………………………..... 47

Figure 3: Previous Cross Sections of Onion Creek ………..................................................... 48

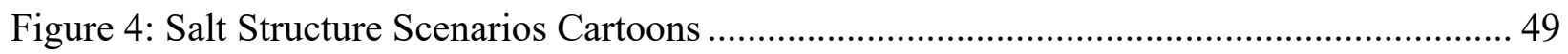

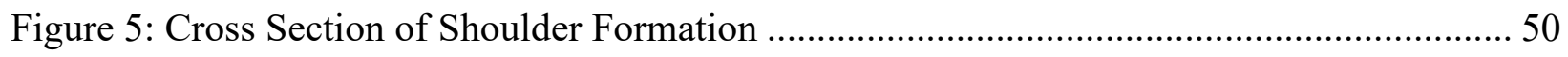

Figure 6: Oil and Gas Wells of Utah and Colorado .................................................................... 51

Figure 7: Conventional Oil and Gas Assessments of the Paradox Basin. .................................... 52

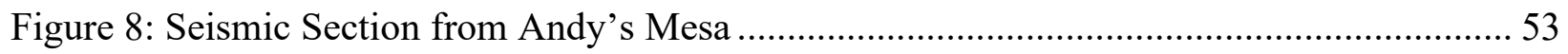

Figure 9: Seismic Section from the Double Eagle Unit........................................................... 54

Figure 10: Amplitude Extraction of the Honaker Trail. ............................................................. 55

Figure 11: Paradox Basin Bouguer Gravity Plate (Case and Joesting 1972). .............................. 56

Figure 12: Fisher Valley Gravity Profile (Case and Joesting 1972)............................................ 57

Figure 13: Paradox Basin Magnetic Map (Case and Joesting 1972).......................................... 58

Figure 14: Nordkapp Basin Magnetic Study on Salt Diapirs. …………………………............ 59

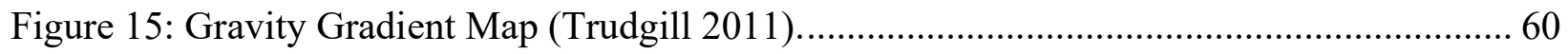

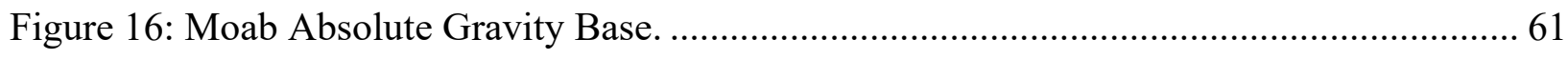

Figure 17: Fisher Valley/Onion Creek Absolute Gravity Base. ..................................................... 62

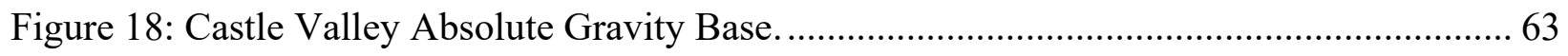

Figure 19: Denisty and Magnetic Susceptibility Values Map ………........................................... 64

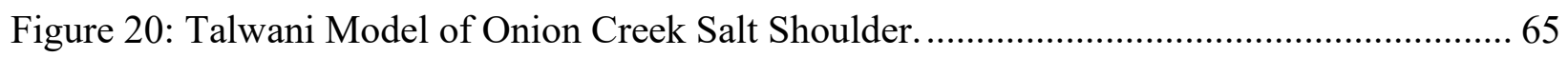

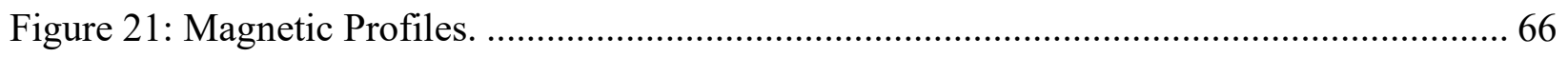

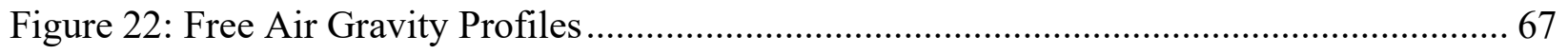




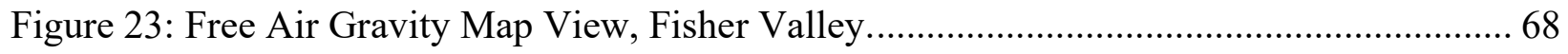

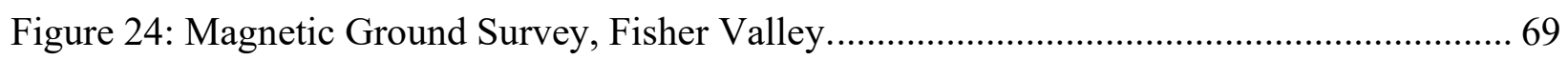

Figure 25: PACES Free Air Gravity Map, Paradox Basin. .......................................................... 70

Figure 26: PACES Free Air Gravity Map with Geology Map..................................................... 71

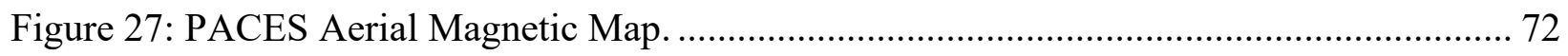

Figure 28: PACES Aerial Magnetic Map with Geology Map.................................................... 73

Figure 29: Onion Creek Cross Section Locations...................................................................... 74

Figure 30: S2 Gravity2DSurf Forward Model Results.............................................................. 75

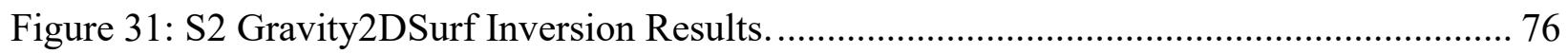

Figure 32: S2 Magnetic2DSurf Forward Model Results......................................................... 77

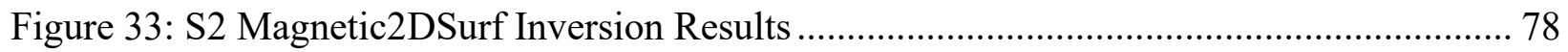

Figure 34: S6 Gravity2DSurf Forward Model Results............................................................. 79

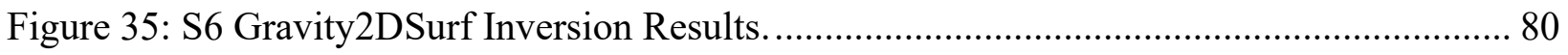




\section{CHAPTER 1: INTRODUCTION}

As of 2011, the U.S. Geological Survey (USGS) assessed the Paradox Basin at 560 million barrels of undiscovered oil, 12,701 billion cubic feet of undiscovered natural gas, and 490 million barrels of undiscovered liquid natural gas (Whidden 2012). In addition to the projected reserves, black shale within the distal portion of the Pennsylvanian Paradox Formation have a TOC range of $0.5-11 \%$, which indicates it is a great source rock (Nuccio and Condon 1996; Rasmussen and Rasmussen 2009). The salt found within the region, also derived from the Paradox Formation, provides the seal for a series of extensive structural and stratigraphic hydrocarbon traps. Similar style traps exist in the Gulf of Mexico, Mississippi Basin, and other hydrocarbon-bearing salt basins around the world. Between the salt diapirs are thick accumulations of sediments deposited in minibasins, which are common in both the Paradox Basin and Gulf Coast, and can be excellent places to search for hydrocarbon-bearing deposits (Kluth and DuChene 2008).

The Paradox Basin is famous for some of the best exposures of salt diapirs worldwide, however, few recent studies using modern concepts in salt tectonics have been applied to the region. This region of the Paradox Basin is shown in Figure 1. Specifically, this study focuses on the Onion Creek salt diapir located just northeast of Moab, Utah (Figure 2). This diapir covers an area of 1.5 by $4 \mathrm{~km}$ where gypsic caprock is exposed at the surface. This caprock is the remaining part of the Paradox Formation, which makes up the salt walls, after near-surface halite dissolution occurred (Doelling 2002b).

Hudec (1995) described the folds seen in the upper layers of the Cutler Group on the northern margin of the Onion Creek salt diapir. He noted these folds suggest a shallow subsurface detachment created them. These folds are anomalous and the detachment surface to 
create them is not well understood even with the folds being well documented (Rassmussen 2009). More detailed mapping of the Cutler Group seeks to reveal what this detachment surface could be and if it is related to subsurface salt or a shale-rich layer (Lankford-Bravo 2019). Previous cross sections of the region also depict these folds but do not provide a concrete solution to what the detachment surface must be other than a possible shale layer. Figure 3 illustrates these previous cross sections (Doelling 2002b; Trudgill 2011). Both authors indicate the folds outcropping on the northern margin of Onion Creek; however, a mechanism for these folds is not clearly described. They also do not indicate any subsurface salt beneath the folds in the Cutler Formation or any detachment surfaces that are required to create these observed folds.

Three different scenarios are possible for the nature of the detachment surface. Figure 4 depicts a simplified version of each possible model (with the expected gravity and magnetic anomalies shown above each model).

The first model involves no salt underlying tight folds, but simply a shale-rich layer within the Cutler Group that acts as a shallow detachment surface to create the folding seen near the surface. This model is roughly the one depicted in the published cross sections of the Onion Creek region in that no body of salt is present beneath the structures in the subsurface (Doelling 2002a; Trudgill 2011). Gravity and magnetics data would show an overall higher magnetic/gravity trend across the folded area if this model was found to be accurate.

The second scenario is a salt namakier, or salt glacier, which consists of a surface outflow sheet of salt (a namakier) derived from the Onion Creek diapir that flowed over the surface of older Cutler strata and was subsequently onlapped and buried by younger Cutler strata (Lankford-Bravo 2019). The shallow detachment would occur within or on top the weak salt 
glacier layer and would display a weaker overall magnetic and gravity reading due to the smaller volume of salt involved.

The third model is a salt shoulder, which represents an instep of the diapir margin onlapped by Cutler Group strata (Figure 5). In this scenario, the shallow detachment is within the salt near the salt/Cutler strata contact (Lankford-Bravo 2019; Langford 2020). "Salt shoulder" is a term first coined by Halbouty (1982) who noted locations of oil accumulations around salt domes are highly affected by the position and shape of the dome throughout geologic time. He described the possibilities for oil and gas accumulations near this salt "shoulder" structure in the Gulf Coast which serve as an analog for the Paradox Basin salt walls. An expected lower gravity and magnetic trend would be present over the shoulder area, but gravity and magnetics should increase dramatically outboard of the shoulder margin with this model due to the large volume of salt at shallow depth.

Salt shoulders have also been studied in Gypsum Valley, Colorado, another location within the Paradox Basin. Here, the Triassic Chinle formation onlapped and overlapped the passive diapir margin. Passive diapiric rise continued approximately $0.5 \mathrm{~km}$ inboard of the older salt wall margin and the shoulder area began to subside with the outboard minibasin. (McFarland 2016; Langford 2018; Giles 2017). This process of salt shoulder formation is thought to be similar at the Onion Creek diapir. However, at Onion Creek the shoulder formation is Permian in age and recorded by the overlying Cutler Group.

In this study I use non-seismic geophysical methods (gravity and magnetics) in order to constrain the nature of the shallow detachment surface and the geometry of the northern margin of the Onion Creek diapir. Results from this study indicate that the salt shoulder model best fits the trends in the gravity and magnetic data. 


\section{CHAPTER 2: GEOLOGIC SETTING AND PREVIOUS STUDIES}

The Paradox basin of the Four Corners region of the United States is made up of a series of roughly northwest to southeast trending salt walls that parallel the front of the Uncompahgre Uplift to the north (Figure 1). Onion Creek diapir is one of these salt walls and is formed within Fisher Valley, which is nearest to the Uncompahgre Uplift. Onion Creek is located just northeast of Moab and about $9 \mathrm{~km}$ east of the Colorado River. It is rather easy to locate in satellite imagery from the distinct white color of the expose gypsic caprock. Just to the east of the diapir within Fisher Valley is a plateau covered by Quaternary alluvium that fills the valley (Figure 2). The geophysical surveys took place here due to its smoother terrain as compared to the rest of the rugged, eroded exposed diapir area.

\section{Geologic History and Stratigraphy}

The formation of the Paradox Basin began in the mid-Pennsylvanian as a flexural foreland basin associated with the Uncompahgre uplift, which is part of the Ancestral Rocky Mountains (Barbeau 2003; Kluth and DuChene 2008; Whidden 2014). Before this uplift, Mississippian limestones dominated the basin in a shallow marine setting, that locally serve as source rocks as well as stratigraphic traps (Dubiel 2009). Repeated glacio-eustatic sea level changes across the area during the early Pennsylvanian allowed for thick evaporite deposits to form within the periodically isolated Paradox Basin. Facies grade from evaporites nearest the thrust front to black shales distal to the thrust front (Whidden 2014). Mixed shallow water marine carbonates and fluvial sandstones of the Pennsylvanian Honaker Trail Formation were deposited over the Paradox Formation.

By the end Pennsylvanian, salt mobilization began with the formation of broad salt

pillows created by differential sediment loading by the Upper Pennsylvanian to Permian Cutler 
Group siliciclastics, derived from the Uncompahgre Uplift. Passive diapirism and concomitant minibasin subsidence started shortly afterward. The salt walls formed over assumed basement faults (Kluth and DuChene 2008; Trudgill 2011), which contributed to the initiation and lineation of the salt walls (Kluth and DuChene 2008; Whidden 2014).

At this time, salt then reached the surface along the assumed basement faults and the Honaker Trail Formation was eroded off these salt crests at Onion Creek on the northern margin. With the salt beginning to weld out, minibasins deepened and sediments ponded preferentially on the northeast side of the salt walls. Overall, salt walls tend to be younger moving to the southwest and older closer to the Uncompahgre front. Also, in the northern region of the basin, synorogenic deposits interfinger with the salt (Kluth and DuChene 2008; Whidden 2014).

The Uncompahgre Uplift is overlapped by Triassic strata, denoting the waning of uplift by the end Permian and complete cessation by the start of the Triassic (Barbeau 2003; Trudgill 2011). By the end of the Triassic, the salt walls reached their present height and thinned flanking strata of Permian and lower Mesozoic units indicate passive diapiric rise throughout their deposition (Kluth and DuChene 2008). By the end of the Jurassic salt movement had ceased and layer-cake stratal geometries are displayed by younger units (Trudgill 2011).

\section{PRe-PARAdoX SEDiments}

These units are key to modeling the subsurface geology. Prior to deposition of the Paradox evaporites, the region was the site of marine shelf deposition (Dubiel 2009; Doelling2002b). These units were also faulted via flexural normal faulting from the nearby Uncompahgre Uplift. The faulting of these units controlled the thickness of the overriding Paradox evaporites and are also believed to control the general lineation of the salt walls in the region (Trudgill 2011). The oldest rocks are various Mississippian limestones. An unconformity 
exists above this unit; then the Molas Formation, a unit containing, cherty, carbonate-clast conglomerates, fine-grained siltstones, sandstones, and karst-filling sediments was deposited. Above the Molas found throughout the Moab region is the Hermosa Group composed of, in order of deposition, the Pinkerton Trail Formation, Paradox Formation, and Honaker Trail Formation (Dubiel 2009). The Pinkerton Trail Formation consists of cyclically interbedded dark gray shale, anhydrites and dolostones. It is up to 400 feet thick around the basin margins but thins towards the basin center (Schamel 2009). This formation is often not shown as a part of many cross sections at Onion Creek and is lumped with the Mississippian rocks (Trudgill 2011; Doelling 2002b). These older, pre-Paradox sediments are found to be a main contributor to hydrocarbon production and hold some importance in the Onion Creek region.

\section{The PARAdox Formation}

The Pennsylvanian Paradox Formation is composed of interbedded evaporites, black shale, and carbonate rock; evaporites include halite, sylvite, carnallite, and anhydrite which can make up to $85 \%$ of the formation. Some intervals of the Paradox Formation contain type II and type III kerogens in the black shale units (Trudgill and Arbuckle 2009; Rasmussen and Rasmussen 2009). Clastic and carbonate rocks are made up of interbedded shale, siltstone, limestone, and dolomite (Doelling 2002a). The Paradox depositional environment consisted of repeated desiccation and flooding of the basin during glacio-eustatic sea level changes that caused the build-up of the evaporite units within the formation. At Onion Creek Diapir there is no halite exposed, only gypsic caprock with local dolomite and black shale inclusions.

\section{The Honaker Trail Formation}

The Honaker Trail Formation is not exposed on the northern margin of the Onion Creek diapir, but is shown in nearby borehole data to be present at depth (Trudgill 2011). This unit is 
composed of interbedded arkosic and micaceous sandstone, conglomerate, and limestone; sandstone is fine to coarse grained, and thick bedded to massive; conglomerate consists of angular pebbles and cobbles of granite gneiss, schist, sandstone, and gneiss; limestone is thick bedded to massive, bioclastic, and interbedded with shaly to sandy calcareous partings (Doelling 2002a). This unit displays a facies change between marine and non-marine deposits with the lower portions composed of more marine rocks such as limestones and dolostones where the upper portions contain more arkosic and micaceous sandstones (Doelling 2002a). It is also noted that this unit is often missing on top of the salt walls in the region; however, at depth it may be as thick as 1,980m. Although not exposed on the northern margin, it is exposed on the southern margin in a structural feature called a megaflap. Megaflaps are layers of steeply dipping, or in some cases, overturned strata, that extend kilometers up the side of a salt diapir (Giles and Rowan, 2012; Rowan et al., 2016; Grisi 2018). An example of this structure can be seen in both cross sections in Figure 3 and is a key feature that must be modeled and considered for the gravity survey.

\section{The CUtLer Group}

The thick siliciclastic succession of the Cutler Group was derived primarily from the exhumed Precambrian crystalline basement of the Uncompahgre Uplift. The depositional environments are primarily nonmarine alluvial fans, debris flows, braided streams, and eolian systems. The basal units locally have intercalated shallow marine limestone beds (Trudgill 2011; Doelling 2002b). The Cutler Group has a wide variety of facies and often has no chronostratigraphic equivalence. Throughout the set of minibasins it can be found with thicknesses varying widely from $0-2450 \mathrm{~m}$. 
There are also a series of climate fluctuations that influenced deposition since overall sea level was low, monsoons occurred, and seasonally wetter climates existed (Dubiel 2009). These climatic differences can be seen in interbedding of fluvial and floodplain rocks with eolian strata. Eustatic sea level changes and some local tectonics controlled marine transgressions and regressions. Accommodation space was rather large allowing for thick sequences of alluvial fan deposits. Salt tectonism also allowed for more accommodation space over time as minibasins subsided and diapirs rose (Dubiel 2009).

Specifically, at the Onion Creek field site, the Cutler Group consists of interbedded red and brown subarkosic, arkosic, and micaceous sandstone and lavender brown conglomerate. The sandstone is fine to coarse-grained, can contain low to high angle cross beds, thinly bedded to massive, and forms smooth round ledges in outcrop. Conglomerate pebbles can range $13-30 \mathrm{~cm}$ across and are composed of quartzite, granite, felsite, gneiss, and schist clasts. The matrix tends to be poorly sorted with fine to coarse-grained sandstones, containing grains of quartz, lithic fragments, mica, and feldspar. These conglomerate units tend to form smooth irregular slopes or gentle ledges. To distinguish the fluvial units from the eolian sandstones, color can sometimes be used, with eolian sandstones being orange to red and fluvial units taking on a darker red to purple hue (Doelling 2002b; Doelling 2002a; Goydas 1990). These units of the Cutler onlap onto the Onion Creek salt diapir and are of interest not just for the onset of salt tectonics in the region, but for the formation of the Onion Creek salt geometry. All the above-mentioned formations vary in facies depending on their proximity to the Ancestral Rocky Mountain uplift (Trudgill 2011; Goydas 1990). 


\section{QUATERNARY DEPOSITS}

Some of these more recent deposits are of concern because they cover the plateau area of interest where the geophysical surveys were performed. In general, the Quaternary deposits of Fisher Valley were deposited by eolian, alluvial, and mass wasting processes and rarely exceed 90m thickness. The sources of these more recent deposits are the sandy components of Paleozoic and Mesozoic sandstones (Goydas 1990). On the northern end of the plateau that composes the Fisher Valley alluvial fan deposits, are present and described as: poorly sorted, angular to subrounded gravel, containing cobbles and sparse boulders and being unstratified (Doelling 2002a).

Cut-and-fill channel features exist locally. Their thickness is commonly less than $15 \mathrm{~m}$ and they are of Holocene to late Pleistocene age (Doelling 2002a). Next, the eolian deposits are described as well-sorted sand and silt deposited in sheets and occasionally dunes with amplitudes less than $1 \mathrm{~m}$. This unit often collects on the lee side of cliffs and slopes; their thickness is rarely more than 15m and is mostly Holocene (Doelling 2002a; Goydas 1990). Lastly, about 0.5m; of volcanic ash derived from the Long Valley eruption and associated with the Bishop Tuff (Doelling 2002b) is found in the study area. This ash lies beneath the eolian and alluvial deposits in the region. The ash's magnetic susceptibility value is about $0.003 \mathrm{emu}$ which is not out of the range of paramagnetic sandstone, making the effect of a thin ash layer rather nominal to the Cutler Formation (Palmer et al 1996). With wider spaced magnetic and gravity surveys the effects of these Quaternary deposits will be averaged and cause less of an anomaly than the large physical property contrasts between the Paradox salt and the Cutler Formation.

\section{NORTHERN MARGIN OF THE ONION CREEK DIAPIR}

The anticlines and synclines in the Cutler Group strata (Figures 2 and 3) are tight near the salt-sediment boundary and broader 500m away from the diapir (Lankford-Bravo 2019; Trudgill 
2011). The depth of fold detachment is difficult to estimate through stratigraphic and structural methods alone due to the thicker sediments in the synclines and thinning on the anticlines in the region. Geophysical studies will help to constrain depth, shape, volume, and extent of the salt concealed at Onion Creek and inverse modeling will provide supplemental constraints that add to the structural analysis done in the region. However, gravity and magnetic data are non-unique and these surface studies are key to constraining subsequent models.

\section{Geophysical Studies}

To further constrain the nature of the northern margin at Onion Creek diapir, the geophysical methods of gravity and magnetics were employed, and previous surveys were also evaluated. Case and Joesting (1972) display a series of magnetic and gravity maps of the Paradox Basin. These help to confirm gravity methods as a powerful tool to map salt structure with large lows over the salt walls of the Paradox Basin. However, this survey does not have the spacing and data density necessary to confirm or deny the finer scale salt structure, or lack of one, in the region. Initial magnetic surveys do not show these salt walls as clearly; however, salt is diamagnetic and in ground surveys should show a low over the salt and a high over the Permian Cutler Group. Inversions will be performed on the collected gravity and magnetic data to estimate depth, shape, volume, and extent of the salt structure at Onion Creek. This information will serve to define and constrain the geometry of the Onion Creek salt wall.

\section{Paradox Basin Hydrocarbons: Andy's Mesa and Double Eagle}

This hydrocarbon assessment of Andy's Mesa might not be directly related to Onion Creek; however, it displays the importance of the Paradox Basin as a play that does contain economic amounts of hydrocarbons while also examining the complicated structures salt can form. Onion Creek does not have the same potential as Andy's Mesa; however, the concealed 
salt structure is just as complicated along the northern margin and serves as an analog to other salt basins and the salt structures that can form there.

In the Paradox Basin, there are four conventional assessment units that could contain oil and gas plays. The many oil and gas wells that occur in the Paradox Basin of Utah and Colorado are shown in Figure 6. The first unit is defined as the Leadville McCracken, an area of elevated hydrothermal flow since the Oligocene containing good porosity and permeability (Whidden 2012). These limestones and sandstones have been displaced along through-going faults. The Leadville makes up one of the basement units at Onion Creek (Doelling 2002b). Although unlikely to hold hydrocarbons in Fisher Valley, this play has other areas of productivity.

A Pennsylvanian carbonate unit built-up from fractured limestone is another noted play. This play contains phylloid algal mounds along topographic highs that were shallow areas of the foreland basin (Whidden 2012). Next are the Permian-Mesozoic reservoir units of south-central Utah that extend into northern Arizona. These units only include the upper reservoirs from Permian time through the Cretaceous in a series of transitional marine to terrestrial sediments. Lastly, from a broader standpoint, there are Paleozoic-Mesozoic reservoir units which contain stacked reservoirs of mixed continental, fluvial clastic rocks (Whidden 2012). Here the traps are often faults due to salt movement with the hydrocarbons getting trapped along the side of salt walls or non-reservoir quality units. Each of these oil assessment units are displayed on Figure 7 with a special interest in the Paleozoic-Mesozoic reservoirs since these relate most closely to the units found at Onion Creek.

Within the Paleozoic-Mesozoic reservoirs as defined by Whidden (2012), Andy's Mesa Federal Unit (AMU) has over 45 wells and over 40 years of production history (Amador et al 2009). Double Eagle, a part of the AMU, has 21 wells. AMU was discovered in 1967 on the 
northern edge of the Gypsum Valley salt wall in Colorado. There were only seven producing wells until 3D seismic was shot in 1998 which completely changed the estimated total recovery to the current assessment of 118 Bcfe (Amador et al 2009). This area of Andy's Mesa is highlighted in Figure 6 along with other oil and gas fields within the Paradox Basin.

The total petroleum system contains source rocks from the Ismay member of the Paradox Formation that are composed of limestone, dolostone, anhydrite, and calcareous black shales. Another probable source is the Cane Creek Member of the Paradox Formation which contains organic-rich rocks (Cole III et al 2009). Next in the sequence, the Honaker Trail is a transitional unit with marine and nonmarine facies present in the form of dolostone, limestone, sandstone, calcareous organic-rich shales, along with some minor anhydrite. The Honaker Trail acts as both a reservoir and seal containing sandstone reservoirs and seals from mudrocks and carbonates. Net sand in the Honaker Trail is around 250-500ft and is mostly evenly distributed since this was just before the onset of salt movement via differential loading processes. Next in the sequence is the Cutler Group also containing both reservoirs and seals. Reservoirs come from the sandstone beds and the seals are very often mudrocks.

The Cutler marks the end of marine deposition and the shedding of sediments from the Uncompahgre uplift. The Cutler varies widely from 100-450ft in thickness at AMU due to the onset of salt movement by this unit. This movement created subtle highs and lows that changed where the Cutler was deposited and how thick it is in areas around the Paradox Basin. The movement of salt also caused faulting to occur along the flanks of the Gypsum Valley salt wall (Cole III et al 2009). An angular unconformity can be seen between the upper and lower Cutler beds due to the movement of salt onset by the Cutler units (Figure 8). These faults extend into the Honaker Trail Formation and act as a major trapping mechanism on the up-dip terminations 
of sandstone reservoirs against the salt wall of Gypsum Valley. The play at Andy's Mesa is between the wet to dry gas window with peak hydrocarbon generation during the Jurassic into Tertiary time, with the noted trapping mechanisms in place by the Cretaceous time (Amador et al 2009).

For Double Eagle, the petroleum system is largely the same since it is a part of Andy's Mesa Unit, however some differences do exist and there are further complications. The source is still the Cane Creek and Ismay Members of the Paradox Formation. The trap/seal the faults caused by the onset of salt movement is still laterally confined by the salt walls, and the reservoirs in the area are largely the same, however, they are mostly from the Honaker Trail and less from the Cutler and Paradox Formation Hermosa Group. Looking closely at the seismic profile in the region (Figure 9), stratigraphic wedges can be seen above and below the Cutler unconformity along with synorogenic faults that cut only through the upper Honaker Trail and lower Cutler Group (Cole III et al 2009). Looking at a map view near this seismic cross section, an amplitude extraction was done on the Honaker Trail interval of the 3D seismic (Figure 10). This interval reveals channel-like features that make up the reservoirs at Double Eagle.

\section{The Mississippi Basin and Gulf CoAst: Hydrocarbons Related to SAlt TeCtonism}

A larger producing field that also contains widespread salt tectonism is the Mississippi Basin of the south-central US. Here there were alternating highs and lows of basement material with thick salt units of the Jurassic Louann Salt deposited on these lows. During the later Jurassic, differential loading onset by the Norphlet Formation fluvial, eolian, rift alluvial, and marine shoreface siliciclastic rocks caused the Louann Salt to become mobile and create a complex array of salt features and salt-related features (Mancini et al 2003). These salt ridges, pillows, anticlines, and turtle structures are known traps within the basin and key to the 
petroleum system along with the sealing dolostones and anhydrites of the Smackover Formation (Mancini et al 2003). Although formed under very different conditions compared to the Paradox Basin, this basin illustrates the need to better understand salt structure in general. By better understanding these traps created by salt and their geometry, more successful wells can be drilled around these complex structures.

Another field that is actively producing hydrocarbons is the Gulf of Mexico. This basin's petroleum system is largely controlled by the allochthonous salt sheets that dominate the structure (McBride et al 1998). In this basin, understanding the migration and evolution of the allochthonous salt is key to pinpointing the areas of petroleum migration, thermal maturation, and traps. Salt is typically impermeable as a migration pathway and deflects petroleum resources up dip of the base of salt/sediment interface (McBride et al 1998). This is why areas next to salt diapirs in a terrestrial environment are often looked at closely if they have sealing potential; the up-dip migration next to impermeable salt allows these areas to be plausible areas for oil and gas production. Although these areas near salt are often great areas to look for oil and gas resources, within the same basin there can be large changes from one minibasin to another. This is the case in the Gulf Coast when interpreting between minbasins, great caution needs to be taken due to local complexities caused by the motion of salt (Rowan et al 2012). This is also the case in the Paradox Basin where Andy's Mesa near the Gypsum Valley salt wall has production, but Onion Creek does not, despite them being a part of the same petroleum system, they are part of different minibasins. Further, the Paradox Basin salt is much more rigid and older than the Gulf Coast salt allowing the Gulf Coast salt to flow in different patterns than we may not immediately expect to find in the Paradox Basin. 


\section{CHAPTER 3: AVAILABLE DATA}

Available data come in two types; geologic data and geophysical data. The focus of this study is the geophysical signatures of the local geology. Geologic maps were used to design survey target areas and correct signals. Geologic data from maps, cross sections, and recent measured sections were used to control geophysical models of the subsurface.

\section{Geologic Data}

A series of geologic maps have been made of the area, the oldest of which still notes the variation in thickness of the Cutler, Moenkopi, and Chinle due to syn-depositional halokinetic deformation (Goydas 1990). This map summary also denotes the onlap of the Cutler Group onto the Onion Creek salt diapir. The synclines and anticlines within this formation are also observed as being related to the deformation of salt beneath it and deposited as a syn-depositional process (Goydas 1990).

Subsequent work by Doelling (2002b) also maps these folds. It was found the folds were tighter near the diapir with limbs dipping at 60 degrees. As he moved away from the diapir he noted the dips change to 17 degrees and then 7-10 degrees in the northern regions furthest from the diapir.

Trudgill (2011) also displays these folds near the surface as being contained within the Permian Cutler Group. The mechanism of how the folds formed is left rather ambiguous within the description of these maps. None of the above-mentioned maps entertain the idea of a salt body at depth related to the diapir or salt wall at Onion Creek.

By splitting the beds of the Cutler Group into distinct mappable units, the syndepositional nature of the tight folds was established (Lankford-Bravo 2019). This deformation 
is over too small an area to be a large tectonic feature and is more likely associated with the deformation of the salt beneath the Cutler Group.

\section{Geophysical Data}

For this study, gravity and magnetics are the methods of choice to analyze the Onion Creek salt diapir. The most recently collected previous gravity and magnetic data for the Paradox Basin is a set of plates consisting of a Bouguer gravity map and an aeromagnetic map constructed for the purpose of exploring for subsurface uranium, oil, and potash (Case and Joesting 1972). This is the most detailed data set available for this region. Other data sets cover larger areas such as the entire state of Utah or the entire western US and do not provide the same level of detail. These data were digitized and now accessible from UTEP's PACES database.

\section{GRAVITY DATA}

The published Bouguer gravity map for this region had a station spacing of $0.8-3.2 \mathrm{~km}$ within the Paradox Basin (Case and Joesting 1972). A Worden gravity meter was used with a precision of $\pm 0.5 \mathrm{mGal}$. Elevation control was within $6-12 \mathrm{~m}$ which translates to an uncertainty of 2-4 mGal. This is due to the limited technology of the time where elevation could only be determined through benchmarks, topographic maps, and transit traverses. Instrument drift was assumed to be $1 \mathrm{mGal}$ per day. Densities of $2600-3000 \mathrm{~kg} / \mathrm{m}^{3}$ were assumed for the Precambrian basement rock, $2550-2650 \mathrm{~kg} / \mathrm{m}^{3}$ for the Cutler Group, and $2200-2350 \mathrm{~kg} / \mathrm{m}^{3}$ for the evaporites of the Paradox Formation (Case and Joesting 1972). Precambrian basement estimates come from igneous rocks exposed on the Uncompahgre Plateau. These density contrasts and gravity anomalies were used to create a set of simple cross sections showing the salt walls in the region ranging from 2100-3000m in height (Figure 12). A Bouguer reduction density of $2670 \mathrm{~kg} / \mathrm{m}^{3}$ was used for all gravity models. Case and Joesting (1972) also noted that Tertiary and Quaternary 
deposits have little influence on the overall geophysical anomalies due to their derivation from the nearby Mesozoic rocks where they share these geophysical properties.

The Bouguer Anomaly map displays very distinct lows over the salt diapirs, making them easy to distinguish from the surrounding rock units (Case and Joesting 1972). However, the station spacing, and lower accuracy of a Worden meter do not provide the level of detail needed to map the Onion Creek salt structure since Case and Joesting's study covers the entirety of the Paradox Basin (Figure 11 and 12). However, it does provide a proof of concept to show gravity is a promising tool for mapping of salt structure.

Another geophysical study, within in the Santos Basin of Brazil, related gravity anomalies to salt structures coupled with seismic data (Constantino et al. 2016). This study assumed halite had a low density $\left(2170 \mathrm{~kg} / \mathrm{m}^{3}\right)$ and high velocity. Inversion modeling was done, but so was forward modeling using the method of Talwani et al (1959). The authors compared a density model constructed without considering the salt to one with salt bodies and found that the model without salt had a much higher degree of mismatch to the observed gravity data than the model made including the salt diapirs (Constantino et al 2016). In the initial stages of my research I also used a software package based on the methods of Talwani et al. (1959) to evaluate forward models of the expected response of the Onion Creek salt shoulder. These tests confirmed I should be able to map salt structure using gravity.

\section{Magnetics Data}

Magnetic methods hinge on the idea that salt (halite) is diamagnetic (having negative susceptibility) or nonmagnetic, as compared to sedimentary rocks which tend to be paramagnetic (Nabighian 2005). The magnetics map of this region consists of an aeromagnetic map over the entirety of the Paradox Basin (Case and Joesting 1972). Data were collected with a continuously 
recording fluxgate magnetometer towed underneath an airplane on a non-metallic cable and winch system (Figure 13). The instrument needed to be towed far enough beneath the plane to avoid interaction with the metallic plane. Often a 10nT correction will be subtracted from the data to correct for the anomaly the plane produces (Balsley 1952). This type of magnetometer records one to three components of the total magnetic field and has a standard precision of $\pm 1 n T$. More precise magnetometers exist today, however, fluxgate magnetometers can still be used. They are known to be rugged since they contain no moving parts and can withstand harsher field conditions (Nabighian 2005; Balsley 1952).

The aeromagnetic surveys appeared best at finding basement faults and intrusive units such as the La Sal Mountains intrusives due to the large scale and depth penetration achieved (Case and Joesting 1972). The Case and Joesting (1972) magnetic map show that the region of Onion Creek is associated with a distinct low. For the purpose of discerning the structure of the Onion Creek salt diapir, these data are not collected at a fine enough scale. A ground survey with much tighter spacing and a higher accuracy and precision instrument was needed, such as a proton procession magnetometer, to locate the salt structure at Onion Creek.

Other more recent studies have shown the use of magnetism for higher resolution studies of salt structure. A survey in the North Sea used a Scintrex cesium magnetometer with a precision of $\pm 0.1 \mathrm{nT}$ for a high-density ( 0.5 to $1 \mathrm{~km}$ spacing) aeromagnetic survey (Gernigon et al. 2011). The North Sea contains salt diapirs of economic interest for oil and gas extraction. Since magnetics is a much cheaper method than seismic, this survey aimed to determine the viability of aeromagnetic surveys (Figure 14). With the higher density survey, salt features were well imaged, especially the edges of the diapirs. Tilt derivative filtering was performed to highlight these edges of salt. Symmetric anomalies were also observed, which may indicate the 
anticlines and synclines associated with the halokinetic sequences. Gernigon et al. (2011) also noted that with smaller spacing, these finer details may be easier to discern from other signals. Therefore, with 100-200m sample spacing at Onion Creek, the antiforms and synforms of the folds may be visible in the magnetic data. 


\section{CHAPTER 4: METHODS}

Two different geophysical methods, gravity and magnetics, were used in this study to constrain the extent, shape, depth, and volume of the salt on the northern margin of the Onion Creek salt diapir. In November 2018, an initial scouting trip was taken to find areas where a gravity survey could be conducted and later a magnetics survey. At this time, a gravity base station was established in the Castle Valley area from the Moab absolute gravity base station by running a series of loops.

A gravity base station was established in the Fisher Valley region that was tied back to the Moab absolute gravity base station (Cook et al. 1971) (Figure 16). Figure 17 describes the established Fisher Valley/Onion Creek gravity base station. The Fisher Valley base station was established by running a series of four loops from the previously established base in the Castle Valley region (Figure 18). The Castle Valley base had been previously tied to an absolute gravity base station in Moab. At Fisher Valley, a pin previously set for a GPS base station was used as a location for the gravity base station on the northwest side of the plateau. By running these loops, an absolute gravity value could be determined for the Fisher Valley base station location.

With the steep cliffs developed in the outcropping of the Cutler Group, it would be difficult to acquire useful GPS information off Onion Creek Road or the adjacent arroyos. Instead, Fisher Valley was chosen as the site for the subsequent surveys since it had a flatter terrain and better view of the sky for the GPS instrumentation. Trudgill (2011) also indicates the salt diapir still continues underneath the plateau, even though the salt is not immediately visible at the surface (Figure 15). The gravity gradient map reveals there is a salt presence and a continuation of the Onion Creek Diapir beneath the Quaternary alluvium of Fisher Valley. 


\section{Gravity Methods}

Paradox Formation evaporites are much less dense, $300-500 \mathrm{~kg} / \mathrm{m}^{3}$ difference, than the sandstones of the Permian Cutler Group. This density contrast suggests that the gravity method may be an excellent way to explore for the subsurface salt. For this survey, a Lacoste and Romberg Gravimeter was used with a precision of $\pm 0.01 \mathrm{mGal}$. The survey was designed across Fisher Valley, an area that covers approximately $1 \mathrm{~km}$ east to west and $2 \mathrm{~km}$ north to south. Station spacing was designed to be dense (175m) with a total of 158 stations collected.

Once the Fisher Valley base station was established, a TopCon GB-1000 rover and base station were used to obtain highly accurate elevation, latitude, and longitude data at each gravity station collected in the valley to assist in gravity corrections. A GPS base station was run for 8 hours each day so that static corrections could be made to the data enabling a higher level of accuracy. The rover GPS was set up with a ten-minute static wait to resolve any ambiguities before the survey would begin. At each station the GPS rover measured signal for 180 seconds to obtain a higher quality data location. The rover was often left to run all day to avoid losing time on a 10-minute static wait between each gravity loop. Often, the GPS rover data would be in the millimeter to centimeter range once corrected from the known base station static reading.

To begin each day, a measurement would be taken at the gravity base station established in Fisher Valley, effectively opening the gravity loop. From there, the gravity measurements were made at each station once navigated to via QGIS or GAIA GPS on a phone or tablet with the pre-loaded maps and survey designs. At each station the GPS would be set to run next to the metal plate the gravimeter would be set on. The gravimeter would be leveled, the mass unlocked to take a measurement, and the dial reading turned until the beam was balanced on the reading line from the left side to center. Once a reading was taken, the battery level, temperature, time, 
and dial reading would be recorded. The GPS would often finish around the same time. From here the spring would be locked and the gravimeter loaded into an oversized hiking backpack to hike to the next point. This process would be repeated until nearly three hours had elapsed. At three hours, a measurement would need to be taken at the base station to close the loop so a linear drift could be assumed in the readings. Typically, three loops would be run per day with nearly 45 points collected per day unless inclement weather occurred.

Most of the gravity data were collected in April 2019, however some were collected in July 2019. This gravity recollection occurred at points where the rover GPS had given some unexpected readings with large error bars, despite the original data appearing reasonable. About 30-40 gravity data points were recollected with new GPS data. New data were also collected in the northeastern side of the plateau along a road leading up to the Exxon \#1 well. This well was a dry hole but contains recorded depths to key units and density changes.

\section{Magnetic Methods}

Magnetic methods are also a powerful way to distinguish salt, having low to negative magnetic susceptibilities (diamagnetic), from sandstones that often have a positive and moderate magnetic susceptibility (paramagnetic). Magnetic surveys were performed with two Geometric Proton Procession Magnetometers with a precision of $\pm 1 \mathrm{nT}$. One magnetometer served as a rover unit and the other as a base station. In November 2018 an initial proof of concept survey was performed with results not proving very promising. However, this survey was only run for $200 \mathrm{~m}$ along Onion Creek Road and likely was not long enough to see the expected anomaly. After the gravity survey in April 2019, a longer magnetics survey was run to test the validity of this method to detect salt. Two lines were run north to south on the plateau, averaging about $2 \mathrm{~km}$ in length, and initial results were more promising. The longer distances allowed a better definition 
of the gradual change from salt to sandstone. A final magnetics survey was designed and collected in July 2019 to provide the necessary data to correlate to the gravity survey.

For the final survey in July 2019, a base station was set up in a magnetically quiet area. The far west side of the plateau was chosen on the edge of a cliff of the Permian Cutler, as far away from the main road as possible. The base station was set up to take a reading every 10 seconds to measure the Earth's ambient magnetic field. This time was chosen as it was assumed to take at least that long to walk between survey points. At the end of the day, the base station was shut down and used to correct the diurnal variation of Earth's magnetic field.

The survey was designed to mimic the survey lines from the gravity survey. Spacing between points was $100 \mathrm{~m}$, a bit denser than the gravity survey as it takes much less time to take a reading with the magnetometer. Spacing between lines was approximately $175-200 \mathrm{~m}$, as it was in the gravity survey. Surveys were designed prior to field work in ArcMap and then imported to GAIA GPS on an iPhone 7 which has a built in GPS even when offline and the ability to store offline maps/data.

While running the survey, the challenge was to collect the data all in one day as it can be difficult to correct magnetic data for diurnal variations from multiple days of data collection. When beginning the survey, care was taken to remove all metal objects except for the phone which contained the survey and a walkie-talkie for safety purposes. The objects were in the same position for every measurement taken to minimize error possible in the measurements. These two anomaly-generating objects were present for every point taken on the plateau, making any interference from them the same for every reading. Five lines of magnetics were collected with each line being approximately $2 \mathrm{~km}$ long. Two kilometers would be walked at a time, then upon reaching the road in the center of the plateau, a break would be taken in a truck to charge the 
phone the maps were on. The survey was run from 5am to $4 \mathrm{pm}$ and temperatures reached 105 degrees Fahrenheit which did not appear to affect the instrumentation. Once data collection was completed, the base station was broken down and programmed to stop data collection. Data were stored on the instruments until it was later exported to MagMap for data corrections.

\section{Geologic Methods and Data Collection}

Some geologic data collection was also conducted to later assist in the modeling process. In July 2019, magnetic susceptibility data were collected along the Fisher Valley plateau to test the magnetic properties of Quaternary sediments. There was some concern that the alluvial fan that formed the plateau might vary in magnetic signature from north to south which would interfere with the detection of salt concealed beneath the sediments. The magnetic susceptibility meters used included a TerraPlus SM30 and KT-10 Magnetic Susceptibility Meter. Data were compared between the two instruments, and even though there were some differences in readings between instruments, no notable change occurred along the north-south profile of the valley within the soils.

Rock samples were also collected to later measure their density and magnetic susceptibility. These rock samples were collected on the northern margin of the Onion Creek salt diapir (Figure 19). Samples were collected from the Paradox gypsic caprock and the Permian Cutler Group. Magnetic susceptibility was tested with the TerraPlus SM30 and KT-10 Magnetic Susceptibility Meter to obtain an average value of each unit to assist with constraints on modeling (Table 1). For density, the mass of each sample was measured and then divided by the volume of displaced water which assisted in modeling constraints for the gravity survey. 


\section{CHAPTER 5: RESULTS}

\section{Initial Results and Older Software Models}

Previous to any geophysical work being completed, a series of forward models were constructed to provide proof of concept that gravity data could be used to distinguish structures of the size, shape, and depth of burial as those expected at the site. These models utilized a program from Talwani (1959) that was improved by Cady (1980) that allows a user to create two-dimensional models of structures and their gravimetric and magnetic responses. Figure 20 shows this model with three layers defined: an alluvium with density $2620 \mathrm{~kg} / \mathrm{m}^{3}$, the Permian Cutler Formation at $2650 \mathrm{~kg} / \mathrm{m}^{3}$, and the Paradox salt at $2170 \mathrm{~kg} / \mathrm{m}^{3}$. This density model is then used to create its expected gravity anomaly. The model shows a nearly $5 \mathrm{mGal}$ drop is observed over the salt body, indicating gravity methods are viable for imaging salt structures in the region, even more subtle structures such as a salt shoulder.

\section{Initial Processing and Trends}

Prior to the use of software developed by Mark Baker, initial processing of the magnetic and gravity data was completed. The magnetic data were downloaded from the instrumentation and imported into MagMap. A base station was run for this study, therefore the diurnal variation in Earth's magnetic field was removed via this program. From there the data were moved to excel. In excel, each reading was assigned a corresponding latitude and longitude and a station number to aid in examining profiles of each magnetic line collected (Figure 21). When inspecting the initial data, it was difficult to determine where the edge of salt might be or which salt structure could be present beneath the surface.

Next, the data were gridded up in a combination of ArcMap and QGIS (Figure 24). These results show lower magnetic readings near the south side of the exposed salt wall that increase 
towards the Cutler mini-basin. Possible causes for the longer wavelength gradient observed in the magnetic data will be discussed further in the Magnetic2DSurf program section. Reduction to pole was not performed on this dataset since it was collected over a small region. Applying this correction to such a small study area would serve as a high pass filter that would only highlight the near surface variations in the magnetism of the Cutler Formation or Quaternary deposits. In the future if the data are combined with a larger regional data set, they would need to have this correction applied.

Gravity data had to undergo a number of corrections as outlined by Hinze et al (2005) and Holom and Oldow (2007). Data corrections included: correction of the instrument dial reading to a value in mGals using an instrument specific calibration table, correction for instrument drift, correction to an absolute gravity value, correction for the shape of the earth (latitude correction) using the international gravity formula of 1967 and the free air correction (equation 5) from Hinze et al. (2005). Latitudes and longitudes for the gravity data were referenced to NAD83 and elevation to NADV88. For the purposes of this study, the Free-Air anomaly was used instead of Bouguer anomaly. The Bouguer anomaly correction assumes a homogeneous infinite slab which is not an accurate representation of the Paradox Basin with $10,000 \mathrm{ft}$ thick salt walls directly next to $9,000 \mathrm{ft}$ thickness of Cutler sediments. Directly modeling the Free-Air anomaly allows the introduction of shallow, variable densities related to salt structure. Other studies by Frese et al (1999) and Leftwich et al (2005) have also made use of the free air gravity anomaly for modeling purposes where the modeling program applies a terrain correction.

Once these corrections were performed, the data were gridded in QGIS and ArcMap with results shown in profile form in Figure 22 via excel. These profiles indicated a larger portion of 
concealed salt might exist due to the multiple-station slope increase from low gravity readings to higher gravity readings. A salt wing or shale detachment model would have an inflection point as compared to this multiple-station slope change. This amount of salt would not be compatible with a salt wing or shale detachment model, suggesting the salt shoulder model might be correct. However, the data would need to be further modeled in $2 \mathrm{D}$ or $3 \mathrm{D}$ to prove the salt shoulder model produced a better fit to the observed data than the other two model. A map view of the Free-Air anomaly data is shown in Figure 23. The lower gravity readings are to the south closer to the exposed salt wall and increase non-linearly as data were collected further north away from the salt wall.

Gravity data for the surrounding region were obtained from the UTEP PACES gravity data base. Although the database is currently not directly accessible to the public, data are still available to UTEP students. Although I attempted to incorporate this much sparser regional data into my study, irreconcilable differences of $13 \mathrm{mGal}$ were found between my study and the base values. Without additional knowledge of how the data base values were originally collected I cannot use these data.

The PACES database also contained an aeromagnetic survey data which were not comparable to the ground survey performed for this study. When in the air, the detector is farther from the anomaly sources on the ground and aerial magnetic maps can look very different (Figure 27). Figure 28 shows a modified version of Doelling's map georeferenced to the satellite image with the same PACES magnetic data overlain on it. This suggests there is some correlation to geology, such as higher magnetism near known volcanic intrusives, but not as strong of a response as one would obtain over known salt walls, where much lower magnetic readings would be expected. 


\section{Modeling Process: First Steps}

A need for new geophysical modeling software was made apparent when the Talwani (1959) and improved Cady (1980) software were used to try and model the initial datasets and salt structure scenarios. The salt geometries drawn for each scenario were difficult for the program to handle given the unique deformational structures salt can form. In each scenario, changing the densities of the top approximately $300 \mathrm{~m}$ did not produce major changes in the calculated gravity curves, likely due to use of the Bouguer anomaly for this software package. This program also lacked a means of conducting gravity inversions. Therefore, I turned to using a software package developed by Mark Baker.

An earlier version of this software used for my project was known as SURF-GRAV and was implemented in a study attempting to locate faults in the Mesilla Bolson region (Khatun 2007). The software was capable of forward modeling in $2 \mathrm{D}$ and $3 \mathrm{D}$ from a large gravity dataset in the El Paso region. It did this via a less detailed density model defined by the user for a 2 by 2 degree area surrounding the region of interest, and a more complex density model in the region of interest. For modeling the 3D component, when a gravity observation was made far away from a geologic object a single line element was used to calculate how the object's density affected the gravity reading, while geologic objects closer to the station were modeled by multiple, more densely sampled, line elements. Free-air gravity was used because of the focus of the study was to model the shorter wavelength features created by faults and not the longer wavelength, deep crustal features. This is also the case for the Onion Creek study, where the target is shallower salt structure concealed beneath the surface of Fisher Valley and not the deeper crustal faults of the foreland basin or other deeper geologic features. 


\section{New Software: Gravity2DSurf and Magnetic2DSurf, DemGeoElev and DrawSection,}

\section{Retrieve}

These new software programs were developed by Mark Baker and tested by Julia Astromovich for the purposes of this study. Before the data could be modeled, a setup process needed to be performed with DemGeoElev.exe and DrawSection.exe to help in the generation of cross sections. The digital elevation model, or DEM, was used to create a topographic profile for a length defined by the user. The spacing, start and end points could be controlled in this software package. From this topographic profile gravity stations could be extracted using Retreive.exe. This program makes use of a csv-type file containing all gravity stations with their latitude, longitude, elevation of reading, DEM reading, and free air anomaly. The topography line end points are entered into the program as well as desired distance from that line to the gravity observations stations that should be extracted. These gravity points would be rearranged into the proper file format before use in the Gravity2DSurf.exe program.

Next, in the setup process is the DrawSection program which uses this profile created in DemGeoElve.exe to extract a set of colors that represent geologic units onto the profile. A geologic map must be made previous to this step that has only the colors defined by the geology with no topography lines, black lines between units, labels, or any other features than the geology. The map I used was heavily modified from the Doelling (2002b) map of Fisher Valley. Once these colors are extracted onto the profile at the surface, a set of pseudo-wells is generated onto the profile where the best estimates of thickness/depth of units are available. This helps immensely in the cross section drawing process. These processes are identical for the magnetic data except the Retreive.exe extraction process has magnetic intensity instead of free air gravity. 
Next, the cross section is drawn with care taken to color match all the needed units. This can be done in drawing programs such as Affinity or Microsoft Paint. Any software that can draw and output a bitmap-type file can be used to create and draw the cross section. Three different cross sections were drawn for the purpose of this study, a shale detachment, salt shoulder, and salt wing model so a proper comparison could be made between the three options. Once drawn, testing of each cross section could begin.

Within Gravity2DSurf, each color is assigned a geologic symbol, the same as the Doelling (2002b) map, and is assigned a range of densities and the most likely density for the unit. For magnetics, this number is a magnetic susceptibility in micro-susceptibility units. From the set of defined densities, and the cross-section location, thickness, and shape, a curve is generated for the forward modeling process. For the inversions, an algorithm changes the densities to most closely match the observed gravity/magnetic curve. By comparing the RMS fit for both the forward and inverse models, a best-fit model can be chosen, so long as densities and magnetic susceptibilities appear reasonable.

\section{Results from Gravity2DSurf and Magnetic2DSurf}

To start, Figure 29 shows the cross sections chosen for the gravity and magnetic profiles. The Doelling cross section that the S2 and S6 profile were based on is also indicated as these cross sections borrowed heavily from this initially drawn cross section. Variations include the exclusion of the collapsed block feature, as it does not appear to be a large extensive feature, and the changing of the salt structure to represent the three plausible scenarios at Onion Creek along the northern margin. S2 had a gravity and magnetic model created from its cross section and S6 had a gravity cross section generated for it. Another handful of sections were planned, along with an east-west profile to tie these sections together for a comparison in $3 \mathrm{D}$, however, this was 
deemed to be beyond the scope of this study. 3D models from these 2D cross sections will be pursued for a future publication and further information can be found in the future works section of this paper.

Figure 30 and Table 2 represent the results from the Gravity2DSurf program. The cross sections were generated via Microsoft 3D Paint and run through CleanStuff.exe to make sure the colors matched the map geologic unit colors. Each of the cross section is the best interpretation of the plausible salt structure present in the shallow surface of the northern margin of Onion Creek along the S2 profile. From these cross sections and the density table inputted into the program (Table 2), a theoretical gravity curve was generated for each of the different cross sections. Between the three salt structure scenarios, the best fit was the salt shoulder. The forward models show a clear best fit for the salt shoulder model but the results of the inversions are a bit more ambiguous. Figure 31 and Table 3 suggests the inversion results are very similar for the 3 starting geometries. However, when comparing the derived densities from the inversion and their RMS fits, the shale detachment model had the worst fit, and the salt shoulder had the best fit according to this RMS value.

Also included on this same set of S2 cross sections is a series of forward and inverse magnetic models from the ground magnetic survey. Figure 32 and Table 4 represent the results of the forward models of the Magnetic2DSurf program. These models do not fit the profile well; however, the salt shoulder model is still found to have the best fit via its RMS value. The magnetic susceptibilities for each unit outlined in Table 4 were the most reasonable values in relation to one another found to fit the profile. The inverse models are a bit more ambiguous in Figure 33 and Table 5. The best RMS fit is still the salt shoulder model, however, the magnetic susceptibilities the inversion process obtained are not compatible with the known geology. For 
example, there are a number of units that have a negative magnetic susceptibility that are siliciclastic or have a known magnetic signature in the paramagnetic (positive susceptibility) range. Thus, these inversion results do not appear reasonable and should not be used as evidence to favor a certain salt structure model over another model.

Lastly, I analyzed the S6 profile which is east of the S2 profile and further from the exposed diapir. Figure 34 and Table 6 display the forward model results. A new set of cross sections were drawn to better fit the gravity profile further east. To do this, the diapir and shallow salt structure were shifted approximately $200 \mathrm{~m}$ south. Following the trend of the salt wall due east did not yield good results. The shift in structure is reasonable with the visible strike of the Cutler Group in satellite view. Even with this shift in the cross section, the salt shoulder model still had the best fit and the density table remained largely as that of the S2 profile, albeit with a few new units; however, these units were not directly below the profile in question and did not directly change results. For the inversions highlighted in Figure 35 and Table 7, there is a very good fit to the observed gravity points. This helps confirm the presence of shallow salt and the need for a shift of the diapir along strike. The model to fit the best was again the salt shoulder model. The densities found in Table 7 are reasonable values for each unit, further suggesting the salt shoulder model is preferable to the wing and shale detachment models. 


\section{CHAPTER 6: DISCUSSION}

Overall, this geophysical study of the northern margin of Onion Creek helped to eliminate some possible models of shallow salt structure. The models strongly suggest the salt shoulder model is most consistent with the observed gravity data, while ruling out the shale detachment and salt wing models. A large volume of concealed salt must be present beneath the surface to generate the observed gravity low between stations 4 and 8 . The magnetic data suggest a similar model supports the observation; however, the fit is not as convincing. There is also the issue of non-uniqueness with these methods of gravity and magnetics. There are multiple solutions to fit the observed data curve, but having more than one geophysical method and having the best available geologic data helps to narrow the possibilities in the models. The magnetic models may not fit well due to a longer wavelength feature in the area interfering with the shallower readings. This could be due to the known basement faults in the region or the nearby La Sal mountain magmatic roots. These effects are very likely superimposed on my magnetic ground survey. Another effect to consider is the magnetic susceptibility variability of the Cutler siliciclastics in the near-surface, which is difficult to model well in combination with the effects of the Quaternary deposits that overlay it. 


\section{CHAPTER 7: RECOMMENDATION FOR FUTURE WORK}

Lingering questions still remain about the northern margin of the Onion Creek salt diapir and the surrounding areas. During the modelling process, the question of the extent of the collapsed block present in Doelling's cross section came to light. Another graduate student had investigated this and the megaflap in the region, confirming their existence (Grisi 2018). The collapsed block fell off of Fisher Mesa on the southside of the Onion Creek exposure and imbedded itself into the southside of the diapir and contains Kayenta through Moenkopi units. However, since both structures are concealed beneath Quaternary deposits, it is almost impossible to tell the extent of these features. It was determined from the geology study the collapsed block was likely a more local feature while the megaflap was likely to extend along the entirety of Fisher Valley since megaflaps are more extensive features that range in kilometers in length adjacent to salt walls (Rowan et al 2016).

Reduction to pole should be performed on the magnetic before this study is brought to any sort of publication. Instead of just assuming this procedure will only enhance the shallow anomalies, it needs to be proven and shown.

3D modeling was considered outside the scope of this thesis; however, the data were collected in a grid pattern with this in mind. A publication with a 3D gravity model is something to work towards in the future. The software was developed from the ground up and working on perfecting this and every 2D cross section needed to transition to 3D will still take well over a month to do. Mark Baker and I have been working on this together since March/April 2020 and continue to do so working out bugs, adding new programs, and adding new features to existing programs. It will continue to be a work in progress for a little while longer. 
In terms of 3D structure, there may be a suggestion from the gridded free air data and profiles that the salt structure dips slightly to the east as one moves across the profiles from west to east. This would need to be accounted for and modeled, along with the diapir trending SE across the Fisher Valley Plateau, as shown between the S2 and S6 profiles.

Future methods that could still be done here would be various seismic surveys. This would likely give the best constraint on depth and the gravity and magnetic surveys completed for my thesis could help guide where to place geophones and shots to obtain the most critical constraints on parts of the salt structure. Although I originally hoped to conduct a seismic survey, this did not take place due to the lengthy approval process. Correspondence with the Moab office of the Bureau of Land Management in November 2018 suggested it would take two years or more for a seismic survey to be approved including hiring an independent biologist, archeologist, and horticulturist to ensure the region contained no rare petroglyphs, plants, animals, etc. in order for the project to be approved. I would highly suggest obtaining a grant prior to starting a seismic survey to help pay for these needed preliminary surveys. The time period of $2+$ years for approval of a seismic study would be more conducive to a $\mathrm{PhD}$ project, with the $\mathrm{PhD}$ student conducting other geophysical or geological mapping while awaiting approval.

Resistivity is also a plausible geophysical technique since salt has a very high resistivity; however, an extremely long survey line would need to be run multiple times across the region to adequately sample to the depths of the salt structure. A SuperSting unit would be capable of such a survey, but the line would need to extend over a kilometer long to reach the 90-300m depth predicted for the salt shoulder structure. A decent-sized crew of 4 to 6 students would be needed to couple all the electrodes to the ground and connect all the cables. Another suggestion would be magnetotelluric methods to search for areas of salt. Much like a resistivity study, this would 
be logistically challenging to move this large equipment over rough terrain and it takes about a day's time to make a measurement at just one field site.

Lastly, a different and more detailed survey could be run. By determining the density and susceptibility for all the units of the Cutler defined by Lankford-Bravo 2020 and having an extremely detailed Quaternary density and susceptibility study, a smaller model could be constructed that looks more at the near-surface features. By tightening the survey area and having closer station spacing, the edge of salt and the start of the instep of the diapir margin could be more easily identified. The current $125 \mathrm{~m}$ spacing on the gravity survey makes it more difficult to pick out these features. 


\section{CHAPTER 8: CONCLUSIONS}

This study reveals the usefulness of non-seismic methods as a tool to map subsurface salt structure and distinguish between these structures. Non-seismic methods offer a cheaper way for smaller to mid-sized oil companies to investigate areas of interest for future wells. By narrowing these areas down, funds can be saved to run more focused seismic surveys over more promising areas. Other than the cheaper cost of operation, gravity and magnetics have proven to be powerful tools in understanding salt tectonic regions. These methods have been utilized to distinguish between plausible salt structures at the northern margin of the Onion Creek salt diapir, something that would have been difficult without this newly developed software.

The shale detachment and salt wing models were able to be ruled out due to their poorer fit compared to the salt shoulder model. This software assists in showing the differences between each salt structure and suggests the salt shoulder as the best fit. Knowing this salt shoulder structure exists at depth fundamentally changes the geologic cross section at Onion Creek from those previously drawn. By pinning down this salt structure, this terrestrial example can serve as an analog for other salt diapirs of more economic interest. Changing the subsurface salt structure from what was previously assumed fundamentally changes where a well would be drilled around this structure and around other structures like it in other hydrocarbon-bearing basins. Salt can act as a trap or seal within a petroleum system. Knowing more about salt deformational structures and how they fit into the petroleum system, can help those in industry drill smarter, more efficient wells around these strangely deformed features. 
Table 1: Samples of the Paradox caprock and Permian Cutler Formation collected in July 2019 (PC19-03:PC19-15). Data includes density $\left(\mathrm{kg} / \mathrm{m}^{3}\right)$ and magnetic susceptibility (unitless). Table accompanies Figure 19 map.

\begin{tabular}{|c|c|c|c|}
\hline Sample & Density $\left(\mathrm{kg} / \mathrm{m}^{3}\right)$ & KT-10 $\left(10^{-3}\right)$ & TerraPlus $\left(10^{-3}\right)$ \\
\hline Paradox & 2016 & -0.01833 & -0.00803 \\
\hline PC19-03 & 2768 & 0.03367 & 0.2260 \\
\hline PC19-04 & 2706 & 0.03833 & 0.03387 \\
\hline PC19-05 & 2583 & 0.03767 & 0.02637 \\
\hline PC19-06 & 2305 & 0.13767 & 0.04790 \\
\hline PC19-07 & 2237 & 0.03600 & 0.02580 \\
\hline PC19-08 & 2472 & 0.01467 & 0.01597 \\
\hline PC19-09 & 2431 & 0.02767 & 0.00847 \\
\hline PC19-10 & 2430 & 0.03400 & 0.05067 \\
\hline PC19-11 & 2566 & 0.08833 & 0.04390 \\
\hline PC19-12 & 2760 & 0.02433 & 0.01403 \\
\hline PC19-13 & 2603 & 0.04467 & 0.03633 \\
\hline PC19-14 & 2295 & 0.00633 & 0.0068 \\
\hline PC19-15 & 2622 & 0.07467 & 0.03310 \\
\hline
\end{tabular}


Table 2: Forward model density (rho) (lower, average and upper density estimate) in units of $\mathrm{g} / \mathrm{cm}^{3}$, used for all three models of cross section S2. Unit labels (left column) come from Doelling 2002b map. Table associated with results shown in Figure 30.

\begin{tabular}{|c|c|c|c|}
\hline Unit & $<$ rho $<>$ & $<$ rho $>$ & $<<$ rho $>$ \\
\hline Air & 0 & 0 & 0 \\
\hline Fr & 2.4 & 2.49 & 2.6 \\
\hline Qaf & 2.1 & 2.25 & 2.4 \\
\hline Qap & 2.1 & 2.25 & 2.4 \\
\hline Qag & 2.1 & 2.25 & 2.4 \\
\hline Qab & 2.1 & 2.25 & 2.4 \\
\hline $\mathrm{Jn}$ & 2.33 & 2.44 & 2.55 \\
\hline $\mathrm{Jk}$ & 2.31 & 2.46 & 2.55 \\
\hline $\mathrm{JW}$ & 2.31 & 2.5 & 2.55 \\
\hline $\mathrm{TR}$ & 2.33 & 2.42 & 2.48 \\
\hline $\mathrm{Trm}$ & 2.33 & 2.43 & 2.48 \\
\hline $\mathrm{P}$ & 2.4 & 2.4 & 2.4 \\
\hline $\mathrm{Pc}$ & 2.38 & 2.52 & 2.48 \\
\hline $\mathrm{Ph}$ & 2.19 & 2.53 & 2.45 \\
\hline $\mathrm{Pp}$ & 2.13 & 2.18 & 2.4 \\
\hline $\mathrm{MI}$ & 2.4 & 2.4 & 2.4 \\
\hline $\mathrm{DC}$ & 2.3 & 2.55 & 2.55 \\
\hline $\mathrm{Yq}$ & 2.6 & 2.75 & 2.75 \\
\hline
\end{tabular}


Table 3: Density tables (in $\mathrm{g} / \mathrm{cm}^{3}$ ) as output from inversions. Left: Shale Detachment RMS: 0.72; Middle: Salt Wing RMS: 0.76; Right: Salt Shoulder RMS: 0.48. Notice these are reasonable density values for the key units: Quaternary, Permian Cutler, and Pennsylvanian Paradox and the best fit via RMS is the shoulder model. Units names come from Doelling 2002b. Density values associated with Figure 31.

\begin{tabular}{|c|c|c|c|c|c|c|c|c|c|c|c|}
\hline Unit & $<$ rho $<>$ & $\langle$ rho $>$ & $<<$ rho $>$ & Unit & $<$ rho $<>$ & $\langle$ rho $>$ & $\langle<$ rho $>$ & Unit & $<$ rho $<>$ & $<$ rho $>$ & $<<$ rho $>$ \\
\hline Air & 0 & 0 & 0 & Air & 0 & 0 & 0 & Air & 0 & 0 & 0 \\
\hline $\mathrm{Fr}$ & 2.4 & 2.5 & 2.6 & $\mathrm{Fr}$ & 2.4 & 2.5 & 2.6 & $\mathrm{Fr}$ & 2.4 & 2.51 & 2.6 \\
\hline Qaf & 2.1 & 2.24 & 2.4 & Qaf & 2.1 & 2.26 & 2.4 & Qaf & 2.1 & 2.22 & 2.4 \\
\hline Qap & 2.1 & 2.26 & 2.4 & Qap & 2.1 & 2.27 & 2.4 & Qap & 2.1 & 2.25 & 2.4 \\
\hline Qag & 2.1 & 2.25 & 2.4 & Qag & 2.1 & 2.25 & 2.4 & Qag & 2.1 & 2.25 & 2.4 \\
\hline Qab & 2.1 & 2.23 & 2.4 & Qab & 2.1 & 2.2 & 2.4 & Qab & 2.1 & 2.31 & 2.4 \\
\hline Jn & 2.33 & 2.44 & 2.55 & $\mathrm{Jn}$ & 2.33 & 2.44 & 2.55 & $\mathrm{Jn}$ & 2.33 & 2.44 & 2.55 \\
\hline $\mathrm{Jk}$ & 2.31 & 2.43 & 2.55 & $\mathrm{Jk}$ & 2.31 & 2.43 & 2.55 & $\mathrm{Jk}$ & 2.31 & 2.43 & 2.55 \\
\hline $\mathrm{JW}$ & 2.31 & 2.47 & 2.63 & $\mathrm{Jw}$ & 2.31 & 2.47 & 2.63 & $\mathrm{Jw}$ & 2.31 & 2.47 & 2.63 \\
\hline TR & 2.33 & 2.42 & 2.5 & $\mathrm{TR}$ & 2.33 & 2.42 & 2.5 & $\mathrm{TR}$ & 2.33 & 2.41 & 2.5 \\
\hline Trm & 2.33 & 2.41 & 2.48 & Trm & 2.33 & 2.41 & 2.48 & Trm & 2.33 & 2.4 & 2.48 \\
\hline $\mathrm{P}$ & 2.4 & 2.4 & 2.4 & $\mathrm{P}$ & 2.4 & 2.4 & 2.4 & $\mathrm{P}$ & 2.4 & 2.4 & 2.4 \\
\hline $\mathrm{Pc}$ & 2.38 & 2.56 & 2.48 & $\mathrm{Pc}$ & 2.38 & 2.55 & 2.48 & $\mathrm{Pc}$ & 2.38 & 2.53 & 2.48 \\
\hline $\mid \mathrm{Ph}$ & 2.19 & 2.68 & 2.45 & $\mathrm{Ph}$ & 2.19 & 2.63 & 2.45 & $\mathrm{Ph}$ & 2.19 & 2.53 & 2.45 \\
\hline$\perp \mathrm{Pp}$ & 2.13 & 2.01 & 2.4 & |Pp & 2.13 & 2.07 & 2.4 & $\mid \mathrm{Pp}$ & 2.13 & 2.18 & 2.4 \\
\hline MI & 2.4 & 2.4 & 2.4 & MI & 2.4 & 2.4 & 2.4 & MI & 2.4 & 2.4 & 2.4 \\
\hline DC & 2.3 & 2.53 & 2.55 & $\mathrm{DC}$ & 2.3 & 2.53 & 2.55 & DC & 2.3 & 2.53 & 2.55 \\
\hline $\mathrm{Yq}$ & 2.6 & 2.7 & 2.75 & Yq & 2.6 & 2.7 & 2.75 & Yq & 2.6 & 2.72 & 2.75 \\
\hline
\end{tabular}


Table 4: Magnetic susceptibility (unitless) (lower, average and upper susceptibility estimates) tables used for all forward models. Associated with magnetic profiles shown in Figure 32.

\begin{tabular}{|c|c|c|c|}
\hline Unit & $<\mathrm{k}<>$ & $<\mathrm{k}>$ & $<<\mathrm{k}>$ \\
\hline Air & 0 & 0 & 0 \\
\hline Fr & 1000 & 1250 & 1500 \\
\hline Qaf & 0 & 10 & 500 \\
\hline Qap & 0 & 10 & 500 \\
\hline Qag & 0 & 10 & 500 \\
\hline Qab & 0 & 10 & 500 \\
\hline Jn & 10 & 50 & 600 \\
\hline Jk & 10 & 50 & 600 \\
\hline JW & 10 & 50 & 600 \\
\hline TR & 50 & 100 & 600 \\
\hline Trm & 50 & 100 & 600 \\
\hline P & 1000 & 1200 & 1500 \\
\hline Pc & 1000 & 1200 & 1500 \\
\hline Ph & 50 & 100 & 600 \\
\hline Pp & -2000 & -1500 & -1000 \\
\hline MI & 100 & 250 & 500 \\
\hline DC & 1400 & 1500 & 1600 \\
\hline Yq & 100 & 150 & 200 \\
\hline
\end{tabular}


Table 5: Magnetic susceptibility tables for the magnetic inversions. Left: Shale Detachment, RMS: 5.28, Middle: Salt Wing, RMS: 5.59, Right: Salt Shoulder, RMS: 3.38. It should be noted that these estimated magnetic susceptibility numbers often do not make physical sense, especially the negative numbers present in units that are not evaporites. Results correspond with Figure 33.

\begin{tabular}{|c|c|c|c|c|c|c|c|c|c|c|c|}
\hline Unit & $\langle\mathrm{k}<>$ & $\langle\mathrm{k}\rangle$ & $\langle\langle\mathrm{k}\rangle$ & Unit & $\langle\mathrm{k}<>$ & $\langle\mathrm{k}\rangle$ & $\langle\langle\mathrm{k}\rangle$ & Unit & $\langle<\mathrm{k}\rangle$ & $\langle\mathrm{k}\rangle$ & $\langle<\mathrm{k}\rangle$ \\
\hline Air & 0 & 0 & 0 & Air & 0 & 0 & 0 & Air & 0 & 0 & 0 \\
\hline $\mathrm{Fr}$ & 1000 & 763.97 & 1500 & Fr & 1000 & -120.15 & 1500 & $\mathrm{Fr}$ & 1000 & 659.85 & 1500 \\
\hline Qaf & 0 & -405.42 & 500 & Qaf & 0 & -603.09 & 500 & Qaf & 0 & -292.96 & 500 \\
\hline Qap & 0 & -244.68 & 500 & Qap & 0 & -236.95 & 500 & Qap & 0 & -52.97 & 500 \\
\hline Qag & 0 & 139.5 & 500 & Qag & 0 & 326.55 & 500 & Qag & 0 & 250.82 & 500 \\
\hline Qab & 0 & -72.47 & 500 & Qab & 0 & -8.67 & 500 & Qab & 0 & 46.24 & 500 \\
\hline Jn & 10 & 598.9 & 600 & $\mathrm{Jn}$ & 10 & 1021.56 & 600 & $\mathrm{Jn}$ & 10 & 588.67 & 600 \\
\hline $\mathrm{Jk}$ & 10 & 994.22 & 600 & $\mathrm{Jk}$ & 10 & 3368.5 & 600 & $\mathrm{Jk}$ & 10 & 1636.34 & 600 \\
\hline $\mathrm{Jw}_{\mathrm{w}}$ & 10 & 1033.23 & 600 & $\mathrm{JW}_{\mathrm{W}}$ & 10 & 4538.86 & 600 & $\mathrm{Jw}$ & 10 & 2085.35 & 600 \\
\hline TR & 50 & 546.23 & 600 & TR & 50 & 3534.29 & 600 & TR & 50 & 1671.4 & 600 \\
\hline Trm & 50 & -71.24 & 600 & Trm & 50 & 3708.82 & 600 & Trm & 50 & 1724 & 600 \\
\hline $\mathrm{P}$ & 1000 & 1250.28 & 1500 & $\mathrm{P}$ & 1000 & 1250.61 & 1500 & $\mathrm{P}$ & 1000 & 1250.23 & 1500 \\
\hline $\mathrm{Pc}$ & 1000 & -4015.52 & 1500 & $\mathrm{Pc}$ & 1000 & -3601.62 & 1500 & $\mathrm{Pc}$ & 1000 & -3324.01 & 1500 \\
\hline $\mid \mathrm{Ph}$ & 50 & 9612.96 & 1500 & | Ph & 50 & 12490.8 & 1500 & | Ph & 50 & 7355.06 & 1500 \\
\hline$\perp \mathrm{Pp}$ & -2000 & -1492.85 & 1500 & | Pp & -2000 & -3399.8 & 1500 & | Pp & -2000 & -3938.92 & 1500 \\
\hline MI & 100 & 287.04 & 500 & MI & 100 & 236.01 & 500 & MI & 100 & 271.27 & 500 \\
\hline DC & 1400 & 1529.37 & 1600 & DC & 1400 & 1694.44 & 1600 & $\mathrm{DC}$ & 1400 & 1596.26 & 1600 \\
\hline $\mathrm{Yq}$ & 100 & 118.17 & 200 & Yq & 100 & 125.42 & 200 & Yq & 100 & 147.15 & 200 \\
\hline
\end{tabular}


Table 6: Gravity forward model densities for each unit of cross section S6. Figure 34 corresponds with this table.

\begin{tabular}{|c|c|c|c|}
\hline Unit & $<\mathrm{rho}<>$ & $<$ rho $>$ & $<<$ rho $>$ \\
\hline Air & 0 & 0 & 0 \\
\hline $\mathrm{Fr}$ & 2.4 & 2.5 & 2.6 \\
\hline Q & 2.4 & 2.4 & 2.4 \\
\hline Qaf & 2.1 & 2.24 & 2.4 \\
\hline Qap & 2.1 & 2.31 & 2.4 \\
\hline Qag & 2.1 & 2.25 & 2.4 \\
\hline Qes & 2.4 & 2.4 & 2.4 \\
\hline Qcb & 2.4 & 2.4 & 2.4 \\
\hline $\mathrm{Kf}$ & 24 & 2.4 & 2.4 \\
\hline $\mathrm{Kd}$ & 2.4 & 2.4 & 2.4 \\
\hline Jn & 2.33 & 2.44 & 2.55 \\
\hline $\mathrm{Jk}$ & 2.31 & 2.43 & 2.55 \\
\hline $\mathrm{JW}_{\mathrm{W}}$ & 2.31 & 2.47 & 2.63 \\
\hline TR & 2.33 & 2.41 & 2.48 \\
\hline Trm & 2.33 & 2.41 & 2.48 \\
\hline $\mathrm{Pc}$ & 2.38 & 2.53 & 2.48 \\
\hline $\mathrm{Ph}$ & 2.19 & 2.65 & 2.45 \\
\hline $\mathrm{Pp}$ & 2.13 & 2.16 & 2.4 \\
\hline MI & 2.4 & 2.4 & 2.4 \\
\hline DC & 2.3 & 2.66 & 2.65 \\
\hline $\mathrm{Yq}$ & 2.6 & 2.68 & 2.75 \\
\hline
\end{tabular}


Table 7: Inversion results for cross section S6. Left: Shale Detachment, Middle: Salt Wing, Right: Salt Shoulder. Inversion density tables. Although the relationships to the units are similar to S2, the inversion densities are slightly higher, but still within reasonable ranges, especially for the best fitting salt shoulder model. Figure 35 contains the profiles generated by these results.

\begin{tabular}{|c|c|c|c|c|c|c|c|c|c|c|c|}
\hline Unit & $<$ rho $<>$ & <rho> & $<<$ rho $>$ & Unit & $<$ rho $<>$ & $<$ rho $>$ & $<<$ rho $>$ & Unit & $<$ rho $<>$ & $\langle$ rho $>$ & $<<$ rho $\rangle$ \\
\hline Air & 0 & 0 & 0 & Air & 0 & 0 & 0 & Air & 0 & 0 & 0 \\
\hline $\mathrm{Fr}$ & 2.4 & 2.5 & 2.6 & $\mathrm{Fr}$ & 2.4 & 2.5 & 2.6 & $\mathrm{Fr}$ & 2.4 & 2.5 & 2.6 \\
\hline $\mathrm{Q}$ & 2.1 & 2.2 & 2.4 & $\mathrm{Q}$ & 2.4 & 2.4 & 2.4 & $\mathrm{Q}$ & 2.4 & 2.4 & 2.4 \\
\hline Qaf & 2.1 & 2.2 & 2.4 & Qaf & 2.1 & 2.34 & 2.4 & Qaf & 2.1 & 2.3 & 2.4 \\
\hline Qap & 2.1 & 2.21 & 2.4 & Qap & 2.1 & 2.5 & 2.4 & Qap & 2.1 & 2.43 & 2.4 \\
\hline Qag & 2.1 & 2.24 & 2.4 & Qag & 2.1 & 2.27 & 2.4 & Qag & 2.1 & 2.26 & 2.4 \\
\hline Qes & 2.1 & 2.24 & 2.4 & Qes & 2.4 & 2.4 & 2.4 & Qes & 2.4 & 2.4 & 2.4 \\
\hline Qcb & 2.4 & 2.4 & 2.4 & Qcb & 2.4 & 2.4 & 2.4 & Qcb & 2.4 & 2.4 & 2.4 \\
\hline $\mathrm{Kf}$ & 2.4 & 2.4 & 2.4 & $\mathrm{Kf}$ & 2.4 & 2.4 & 2.4 & $\mathrm{Kf}$ & 2.4 & 2.4 & 2.4 \\
\hline $\mathrm{Kd}$ & 2.4 & 2.4 & 2.4 & $\mathrm{Kd}$ & 2.4 & 2.4 & 2.4 & $\mathrm{Kd}$ & 2.4 & 2.4 & 2.4 \\
\hline $\mathrm{Jn}$ & 2.33 & 2.44 & 2.55 & $\mathrm{Jn}$ & 2.33 & 2.44 & 2.55 & $\mathrm{Jn}$ & 2.33 & 2.44 & 2.55 \\
\hline $\mathrm{Jk}$ & 2.31 & 2.43 & 2.55 & $\mathrm{Jk}$ & 2.31 & 2.43 & 2.55 & $\mathrm{Jk}$ & 2.31 & 2.43 & 2.55 \\
\hline $\mathrm{Jw}$ & 2.31 & 2.47 & 2.63 & Jw & 2.31 & 2.46 & 2.63 & $\mathrm{Jw}$ & 2.31 & 2.47 & 2.63 \\
\hline $\mathrm{TR}$ & 2.33 & 2.41 & 2.48 & $\mathrm{TR}$ & 2.33 & 2.4 & 2.48 & TR & 2.33 & 2.4 & 2.48 \\
\hline Trm & 2.33 & 2.41 & 2.48 & Trm & 2.33 & 2.41 & 2.48 & Trm & 2.33 & 2.41 & 2.48 \\
\hline $\mathrm{Pc}$ & 2.38 & 2.57 & 2.48 & $\mathrm{Pc}$ & 2.38 & 2.46 & 2.48 & $\mathrm{Pc}$ & 2.38 & 2.46 & 2.48 \\
\hline $\mid \mathrm{Ph}$ & 2.19 & 2.95 & 2.45 & $\mathrm{Ph}$ & 2.19 & 2.57 & 2.45 & $\mathrm{Ph}$ & 2.19 & 2.45 & 2.45 \\
\hline $\mid \mathrm{Pp}$ & 2.13 & 2 & 2.4 & $\mid \mathrm{Pp}$ & 2.13 & 2.25 & 2.4 & |Pp & 2.13 & 2.09 & 2.4 \\
\hline MI & 2.4 & 2.4 & 2.4 & MI & 2.4 & 2.4 & 2.4 & MI & 2.4 & 2.4 & 2.4 \\
\hline DC & 2.3 & 2.54 & 2.55 & $\mathrm{DC}$ & 2.3 & 2.53 & 2.55 & $\mathrm{DC}$ & 2.3 & 2.5 & 2.55 \\
\hline $\mathrm{Yq}$ & 2.6 & 2.65 & 2.75 & $\mathrm{Yq}$ & 2.6 & 2.65 & 2.75 & $\mathrm{Yq}$ & 2.6 & 2.66 & 2.75 \\
\hline
\end{tabular}




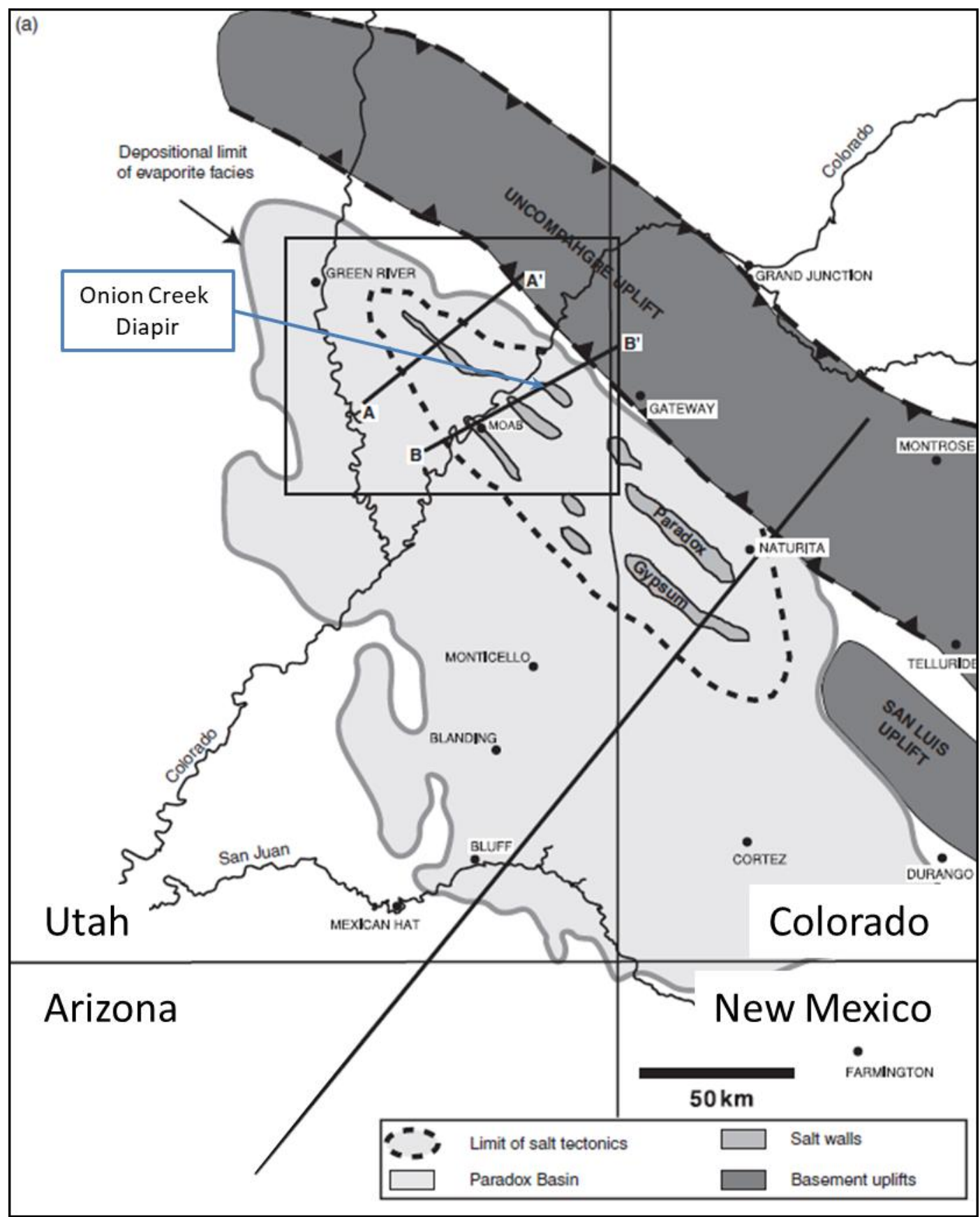

Figure 1: An overview of the location of the Paradox Basin in Utah and Colorado. The Uncompahgre Uplift is the source of the Paradox and Cutler Formations that formed the Paradox Basin. The more proximal part of the basin contains the salt walls the basin is known for. A few studies reference Gypsum Valley, labeled on this map and found in the basin within Colorado. In this study, the focus is the Onion Creek salt diapir (Modified from Trudgill 2011). 


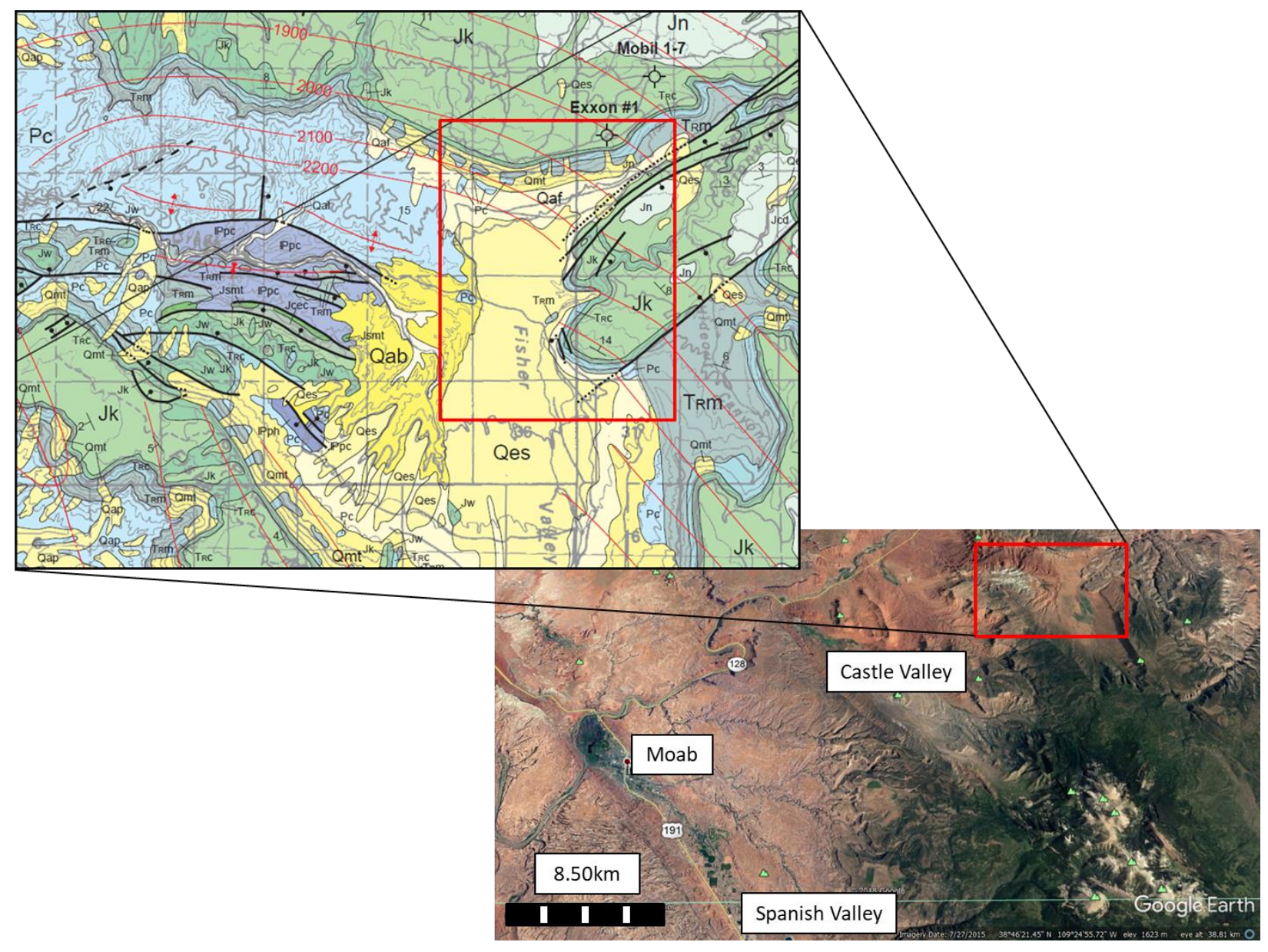




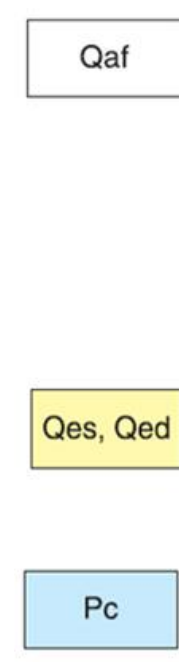

Alluvial-fan deposits -- Poorly sorted, angular to subrounded gravel, containing cobbles and sparse boulders, in crudely bedded to unstratified granules, sand, silt, and clay matrix; cut-and-fill channel features locally present; deposited at the foot of mountains, cliffs, and at the mouths of streams; thickness commonly less than 15 meters $(50 \mathrm{ft})$; Holocene to late Pleistocene.

Eolian deposits -- Well-sorted sand and silt; deposited in sheets (Qes) and dunes (Qed); commonly fills hollows in sandstone outcrops or collects on the lee sides of cliffs and slopes; thickness 15 meters ( $50 \mathrm{ft}$ ) or less; mostly Holocene.

Cutler Formation -- Interbedded redbrown subarkosic, arkosic, and micaceous sandstone and lavenderbrown conglomerate; sandstone is fine to coarse grained and gritty in eastern exposures; low- to high-angle crossbeds, thin bedded to massive, and forms smooth and rounded ledges; conglomerate is mostly pebbles to 13centimeter (5-inch) cobbles, but cobbles exceeding 30 centimeters ( $1 \mathrm{ft}$ ) or more in diameter are common in the eastern part of the quadrangle; mostly quartzite, granite, felsite, gneiss, and schist clasts; matrix is poorly sorted, fine- to coarsegrained sandstone, with grains of quartz, lithic fragments, mica, feldspar, and unidentified black minerals; laminated to indistinct bedding; weathers to smooth irregular slopes or gentle ledges; lower contact is placed above a gray limestone ledge that contains Late Pennsylvanian (Virgilian) fusulinids; 0 to 2,450 meters $(0-8,000 \mathrm{ft})$ thick; missing over some salt-cored anticlines, thickest at the west edge of the

Uncompahgre uplift; as much as 1,000 meters $(3,300 \mathrm{ft})$ exposed; 75 meters (245 ft) of gray-white, cross-bedded quartzose sandstone at the top of the Cutler Formation in the north part of the southwest flank of Castle Valley may be an outcrop of White Rim Sandstone; Lower Permian.

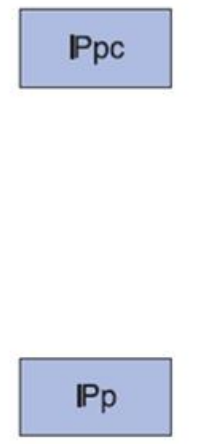

Paradox Formation caprock -- Mostly light-gray, contorted gypsum with interlayered black and gray shale, thin chippy limestone, and sandstone; locally exposed in salt valleys and along saltdissolution deformed bedrock; caprock is the residue after salt is dissolved from the Paradox Formation; up to 200 meters $(650 \mathrm{ft})$ exposed and may reach a total of 350 meters $(1,150 \mathrm{ft})$ in the subsurface.

Paradox Formation (shown on cross sections only) - Interbedded evaporite, clastic, and carbonate rocks; evaporites include finely laminated halite, sylvite, carnallite, and anhydrite and may constitute as much as 85 percent of the formation; clastic and carbonate rocks are interbedded shale, siltstone, limestone, and dolomite and are grouped into "marker beds" (Hite, 1977); includes Pinkerton Trail and Molas Formations (see lithologic column); 0 to 1,370 meters $(0-4,500 \mathrm{ft})$ thick in Paradox basin, but as much as 4,300 meters $(14,100 \mathrm{ft})$ thick in saltcored anticlines, salt commonly missing adjacent to salt-cored anticlines, formation missing on Uncompahgre uplift; Middle Pennsylvanian.

Figure 2: Map: An overview of the Onion Creek salt diapir and plateau to the east where the geophysical surveys were completed. Normal faults are located around the edges of the diapir and a series of folds. A few wells are also marked on this map. Legend: Only the relevant units were included; the Qaf, Qes, Qed, Permian Cutler, Pennsylvanian Paradox caprock, and Pennsylvanian Paradox Formation. These will be the units encountered for the geophysical surveys; therefore, the properties of these units must be determined (modified from Doelling 2002b). 

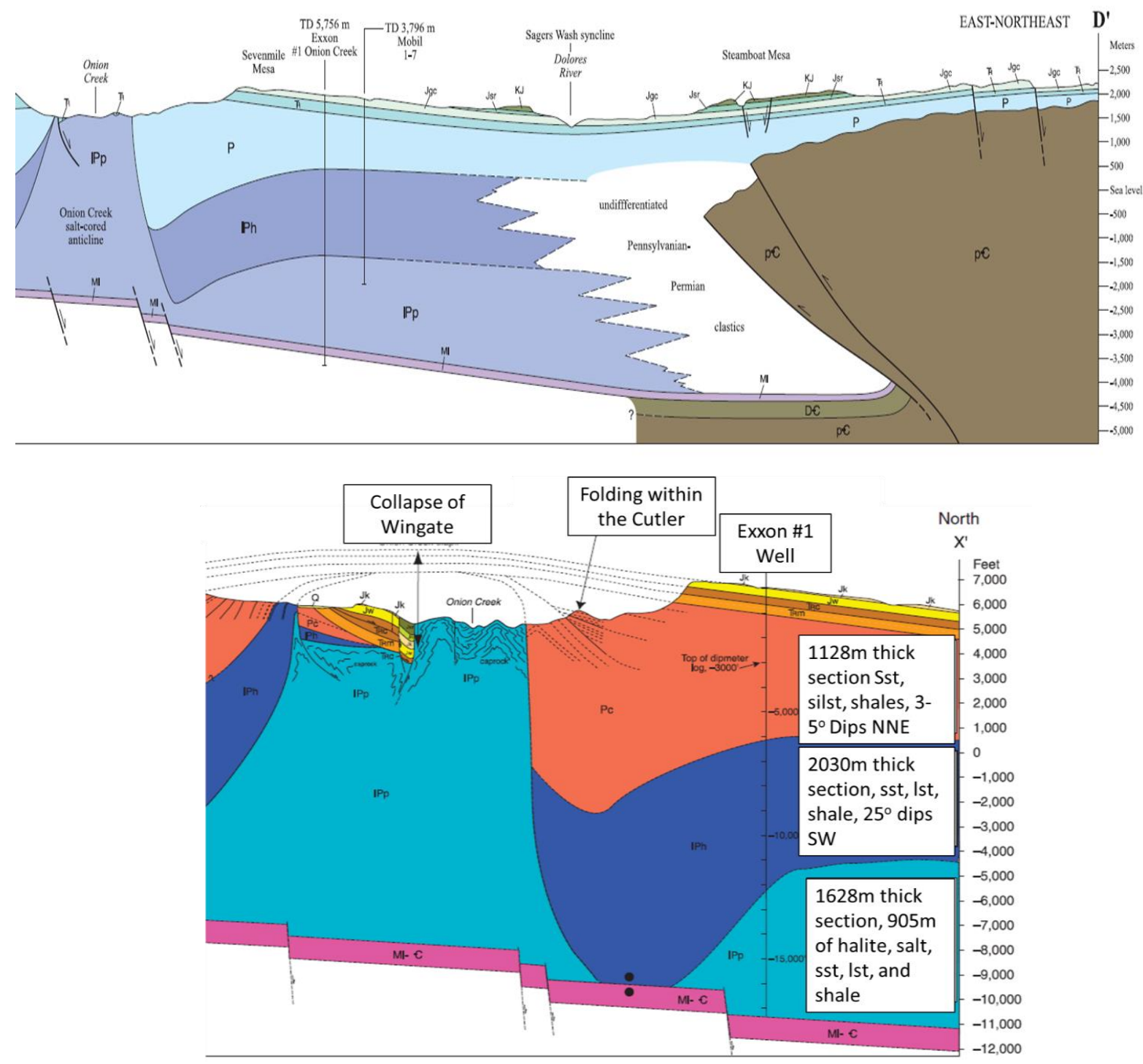

Figure 3: Previous Cross Sections of Onion Creek.

Top: Modified from Doelling (2002b) Cross Section of Onion Creek, this depicts the folds on the top of the Cutler Formation but indicates no other salt structure present.

Bottom: Modified from Trudgill (2011) Cross Section of Onion Creek, well information helps to constrain layers, however this also fails to describe a mechanism for the folds in the upper Cutler Formation. 

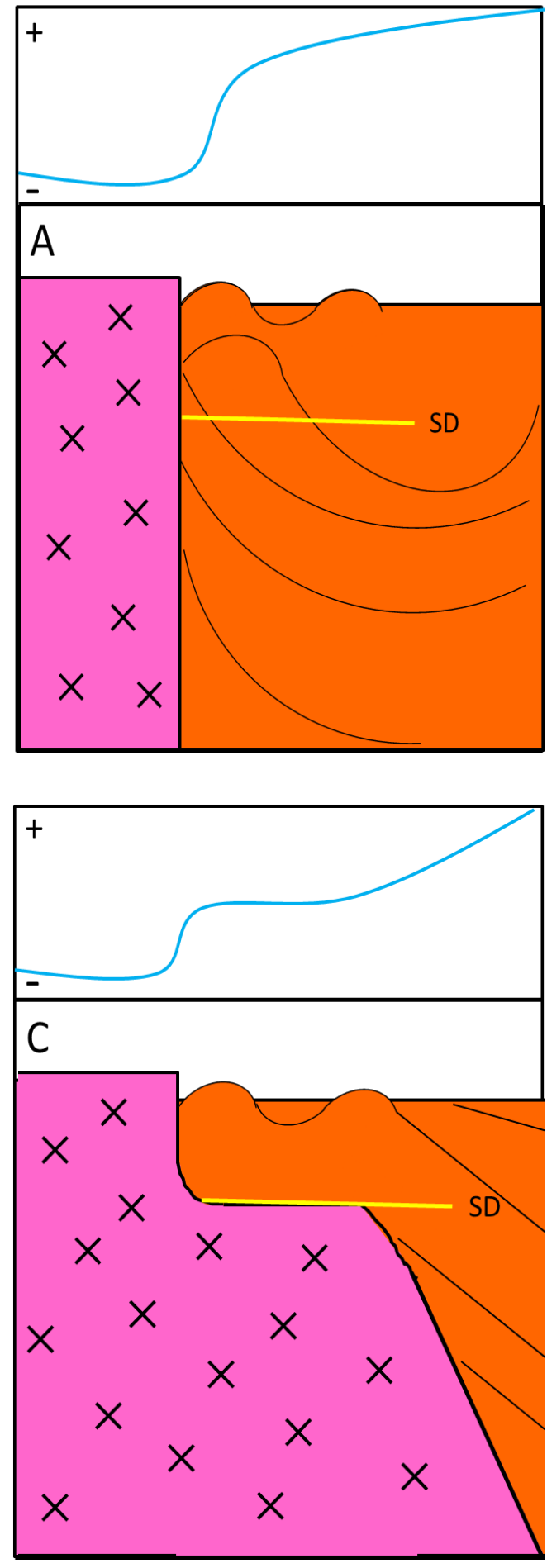

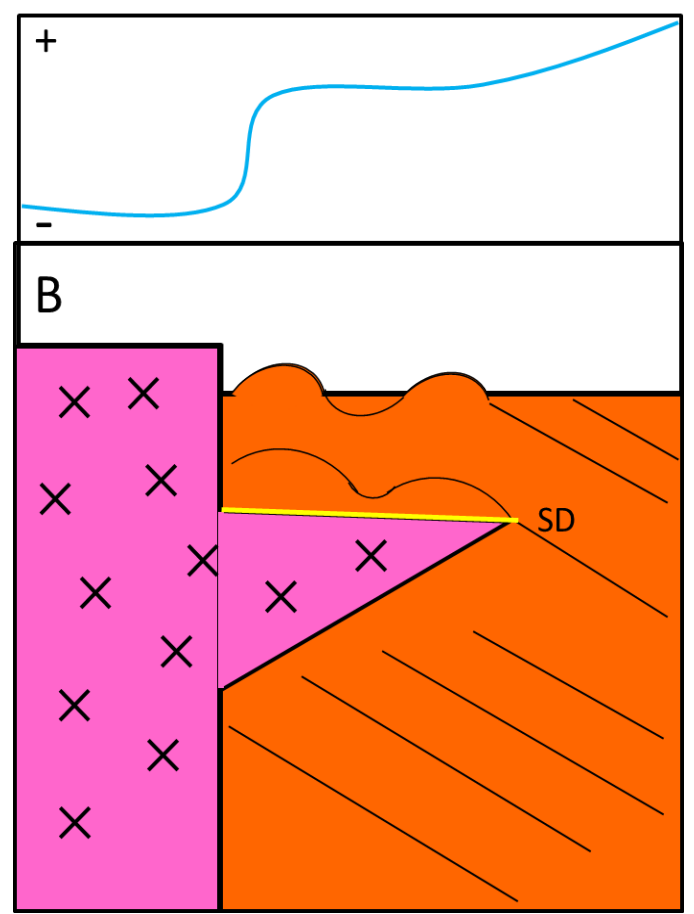

Figure 4: Possibilities that may have produced the folds present in the shallow section of the Cutler Group, pink is the Paradox salt, red is the Cutler Group, yellow is the shallow detachment layer indicated by SD. The profiles with blue lines indicate the rough gravity and/or magnetic profile expected for each scenario

A) Shallow Detachment: A weak layer (likely shale) acts as a detachment surface to create the folds in the near-surface

B) Salt Namakier: A salt glacier, salt reaches the surface during diapir rise and covers part of the surface, then later becomes buried by the continued deposition of the layers above. A detachment occurs along the salt surface C) Salt Shoulder: Shallow detachment occurs on the weak salt layer, syn-depositional folding takes place at the surface to the edge of the concealed salt structure. 


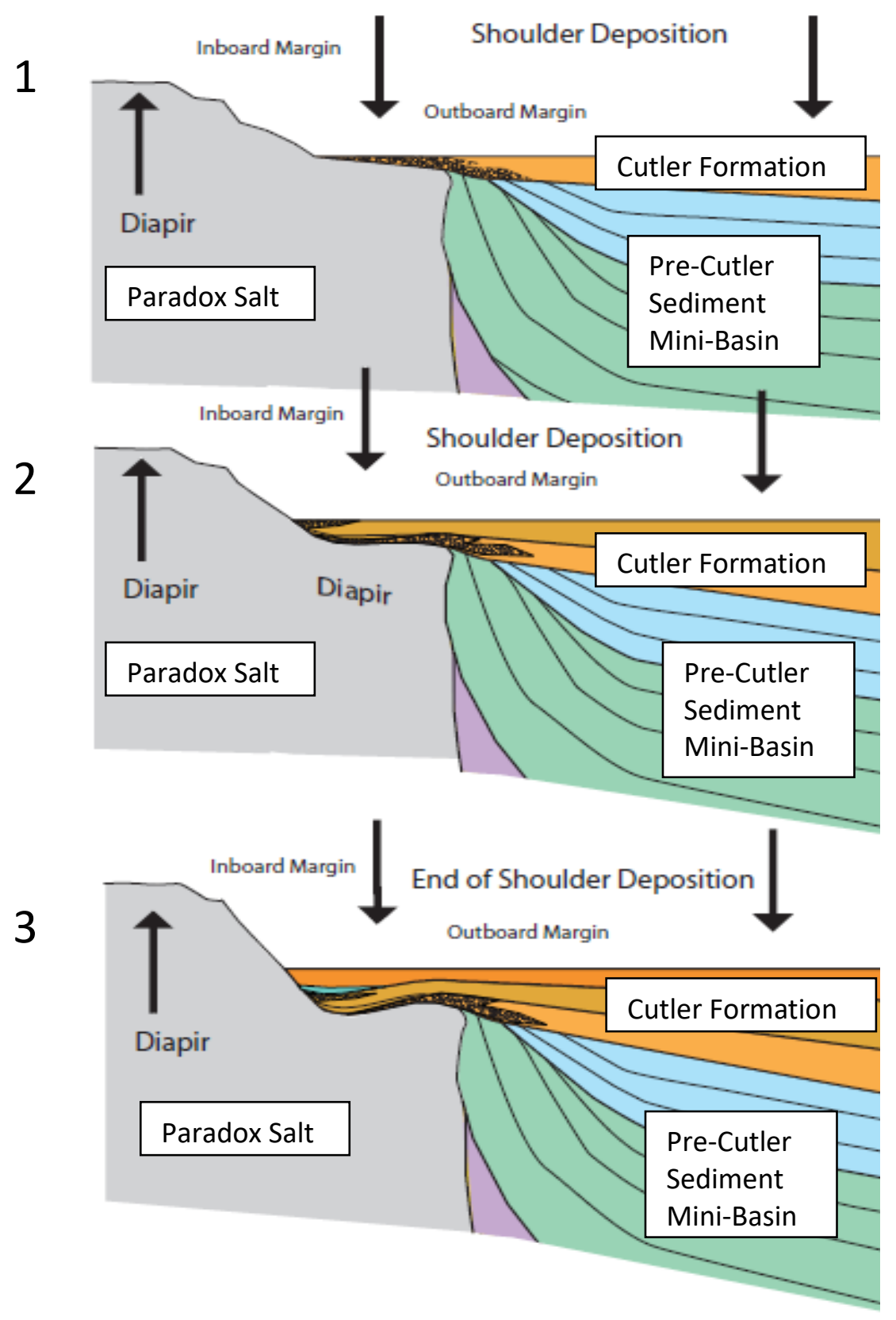

Figure 5: Illustration of salt shoulder formation. 1) Pre-Cutler sediments have already been deposited along the sides of the diapir, the Cutler Formation begins to be deposited, causing the onset of diapir rise and subsidence of the minibasin, some pieces of the caprock may be included in the inboard margin. 2) More of the Cutler Formation onlaps onto the diapir, deepening the basin and starting the formation of the salt shoulder. 3) The final geometry of the salt shoulder, antiforms and synforms can be viewed in the Cutler Formation (modified from Langford et al 2019). 


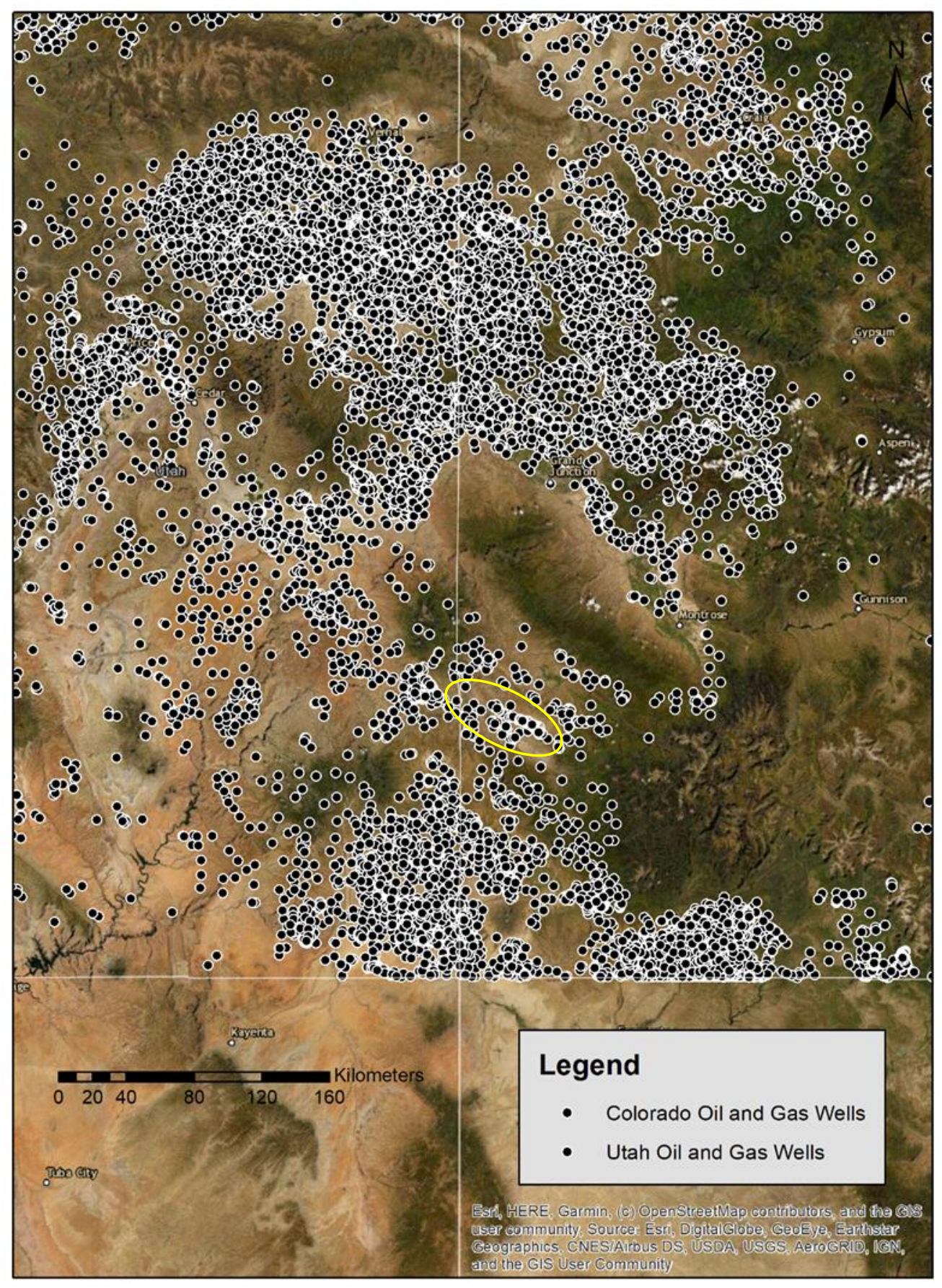

Figure 6: Documented oil and gas wells of Utah and Colorado near the Paradox Basin. Highlighted by the yellow oval is the Andy's Mesa Unit. The Paradox Basin still has potential of oil and gas production. 


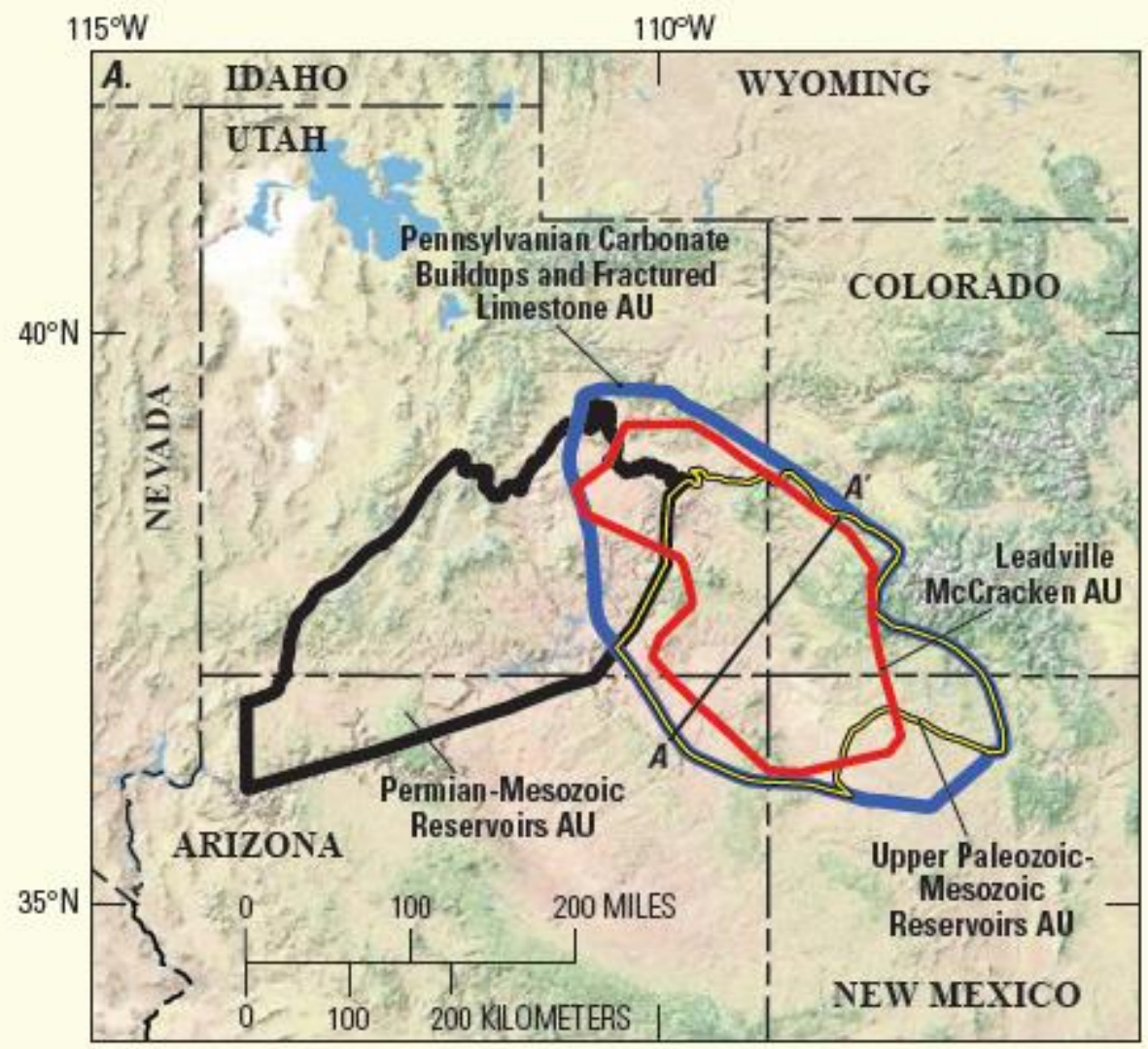

Figure 7: Four conventional oil and gas assessment units of the Paradox Basin. Red: Leadville McCracken, Yellow: Upper Paleozoic-Mesozoic Reservoirs, Blue: Pennsylvanian Carbonate Buildups and Fractured Limestone, Black: Permian-Mesozoic Reservoirs (modified from Whidden 2012). 


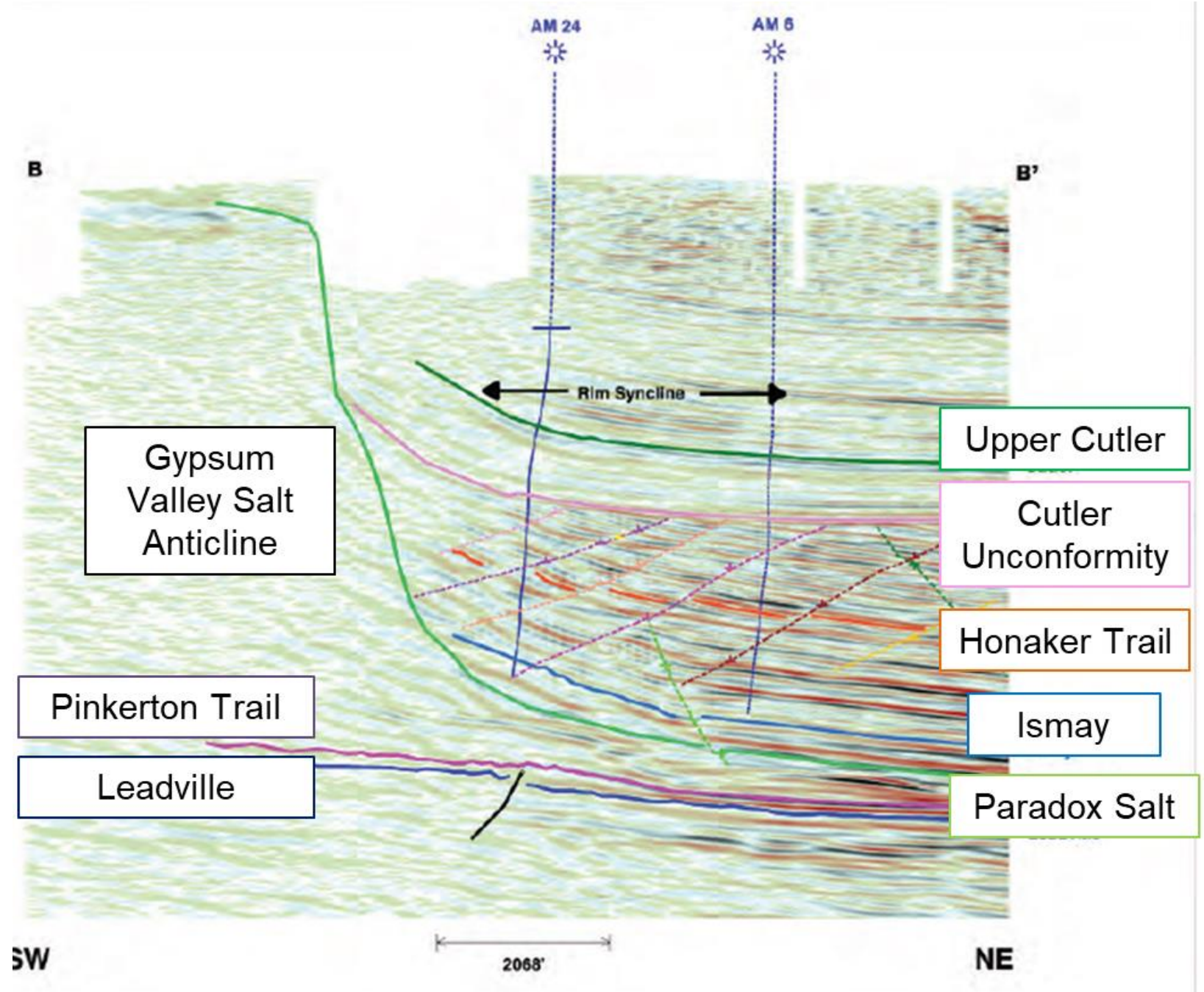

Figure 8: Seismic acquired from Andy's Mesa Unit. The Ismay member of the Paradox Group is known to be the source rock. Faults cut through the upper Honaker Trail and lower Cutler with the upper Cutler not affected by the faulting. Faulting is due to the onset of salt movement caused by the differential loading process of the loading of the Cutler Group siliciclastics onto the evaporite units of the Paradox Formation. (modified from Amador et al 2009) 


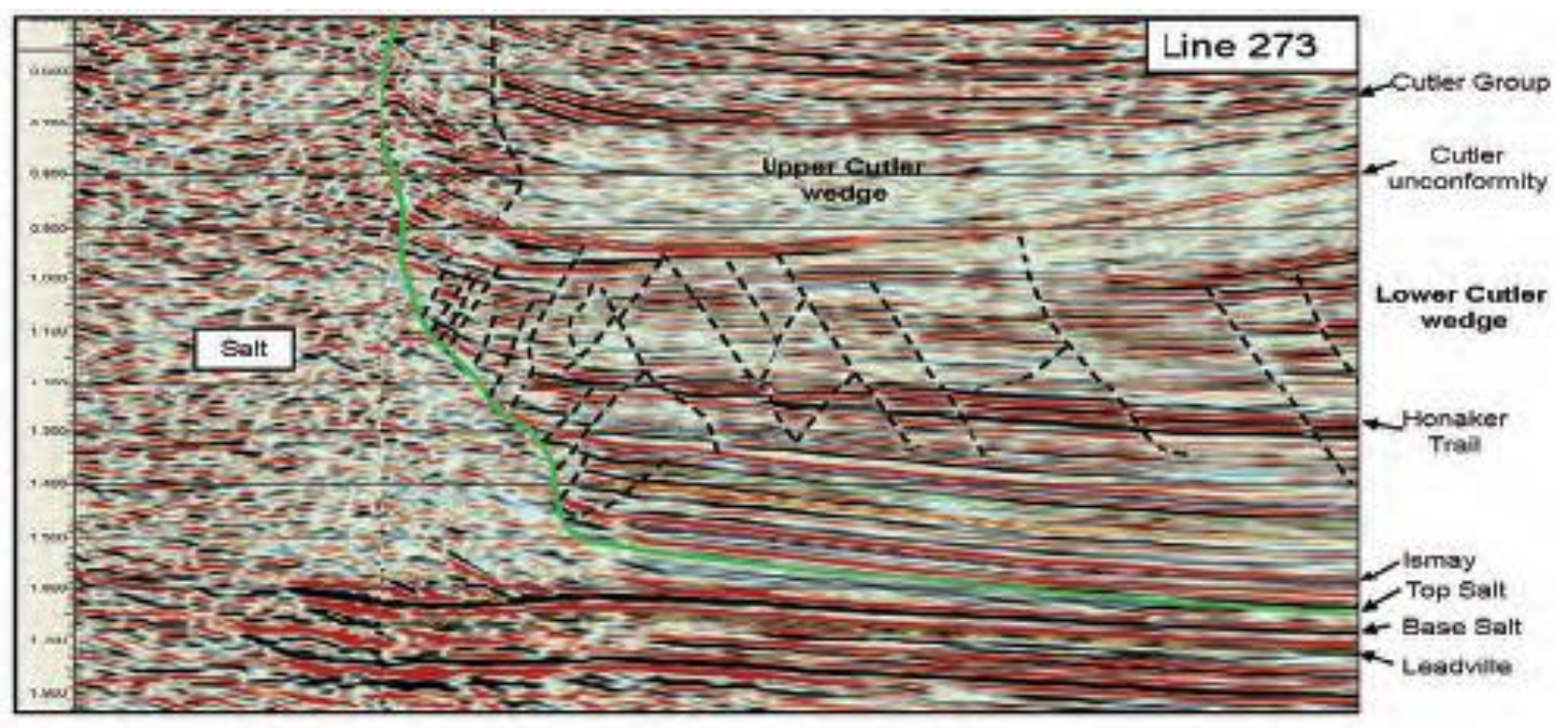

Figure 9: Double Eagle Unit seismic section. The top salt, salt wall, and Ismay source can be seen in this section. The upper Honaker Trail and lower Cutler also experience faulting due to the onset of salt movement. The upper Cutler wedge is not faulted. The salt is also clearly visible as marked by the green line. (modified from Cole III et al 2009). 


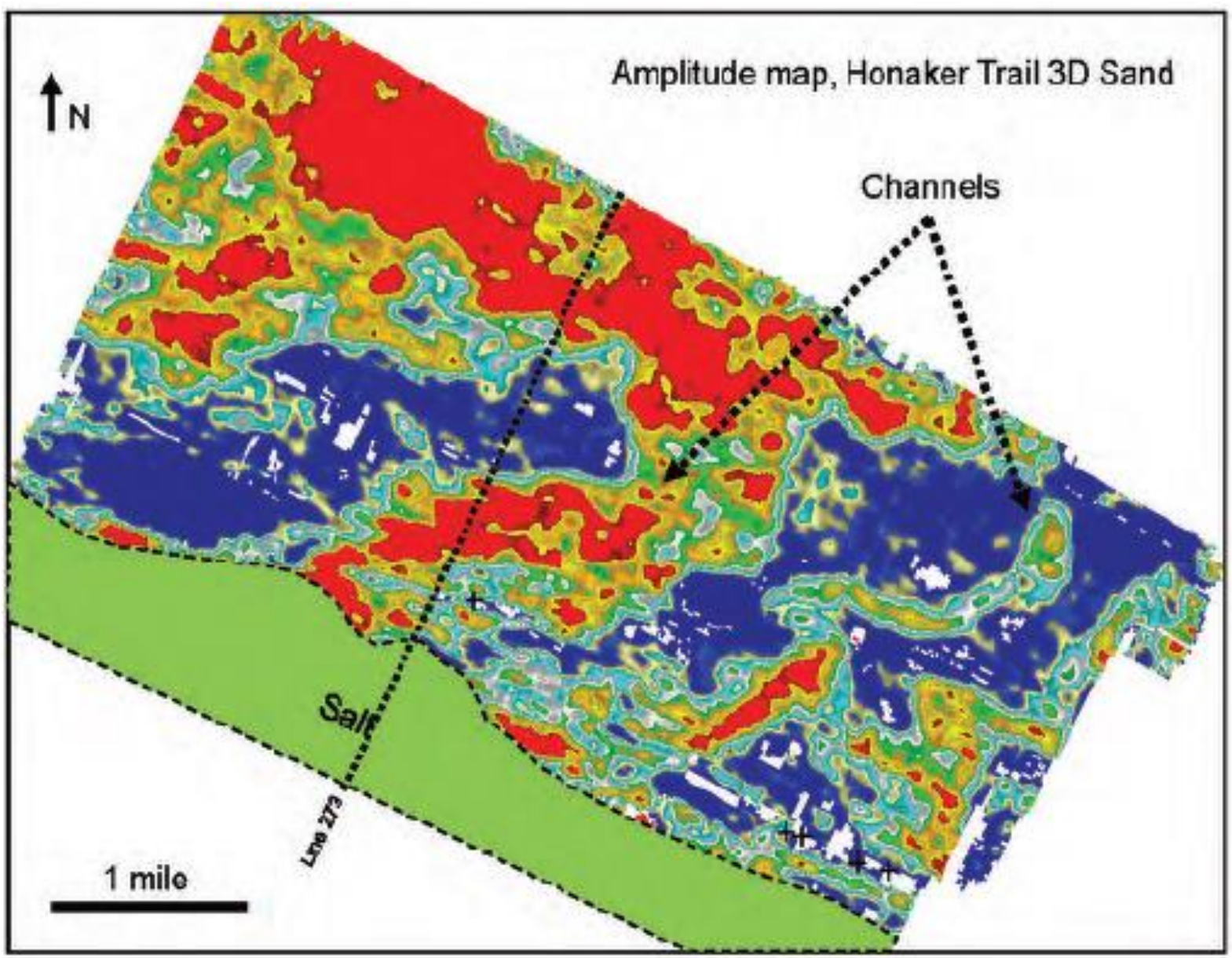

Figure 10: Amplitude extraction of the Honaker Trail with channel shows. Hotter colors represent a more continuous amplitude in the seismic and cooler colors represent less continuous amplitudes. The more continuous sections often represent sands and reservoirs. The hotter colors can be seen forming a channel-like pattern in the Honaker Trail. (modified from Cole III et al 2009). 


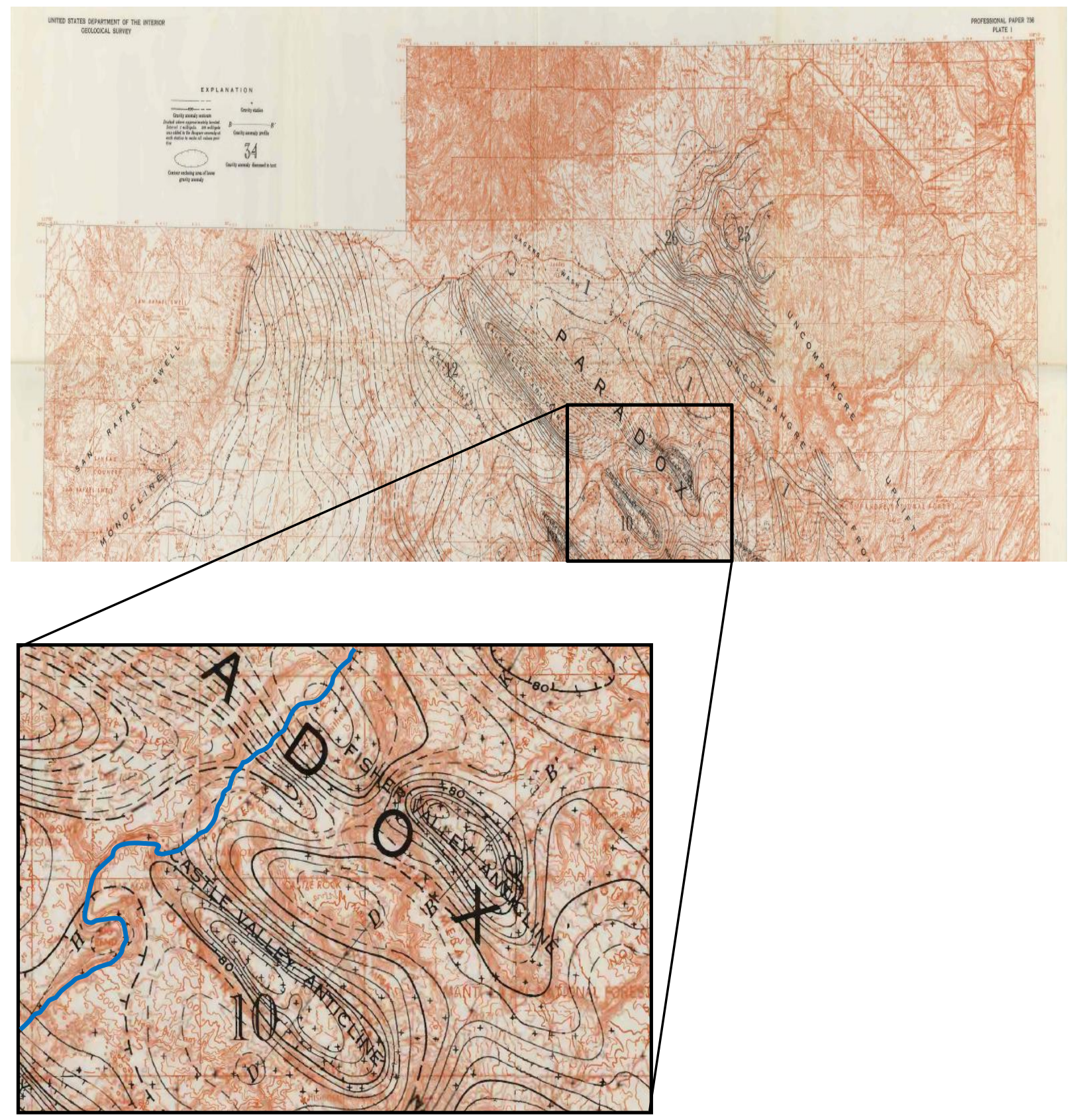

Figure 11: A Bouguer gravity map of the Paradox basin. Survey conducted with a Worden gravity meter with accuracy of $\pm 0.5 \mathrm{mGal}$. The small +'s on the map denote station locations which appear at the closest $0.5 \mathrm{~km}$ apart. Here the Fisher Valley/Onion Creek diapir and the Castle Valley salt wall are clearly seen as gravity lows. With a smaller spaced survey and better technology, the salt shoulder at Onion Creek may be able to be imaged. The Colorado River is highlighted in blue for location orientation (modified from Case and Joesting 1972). 

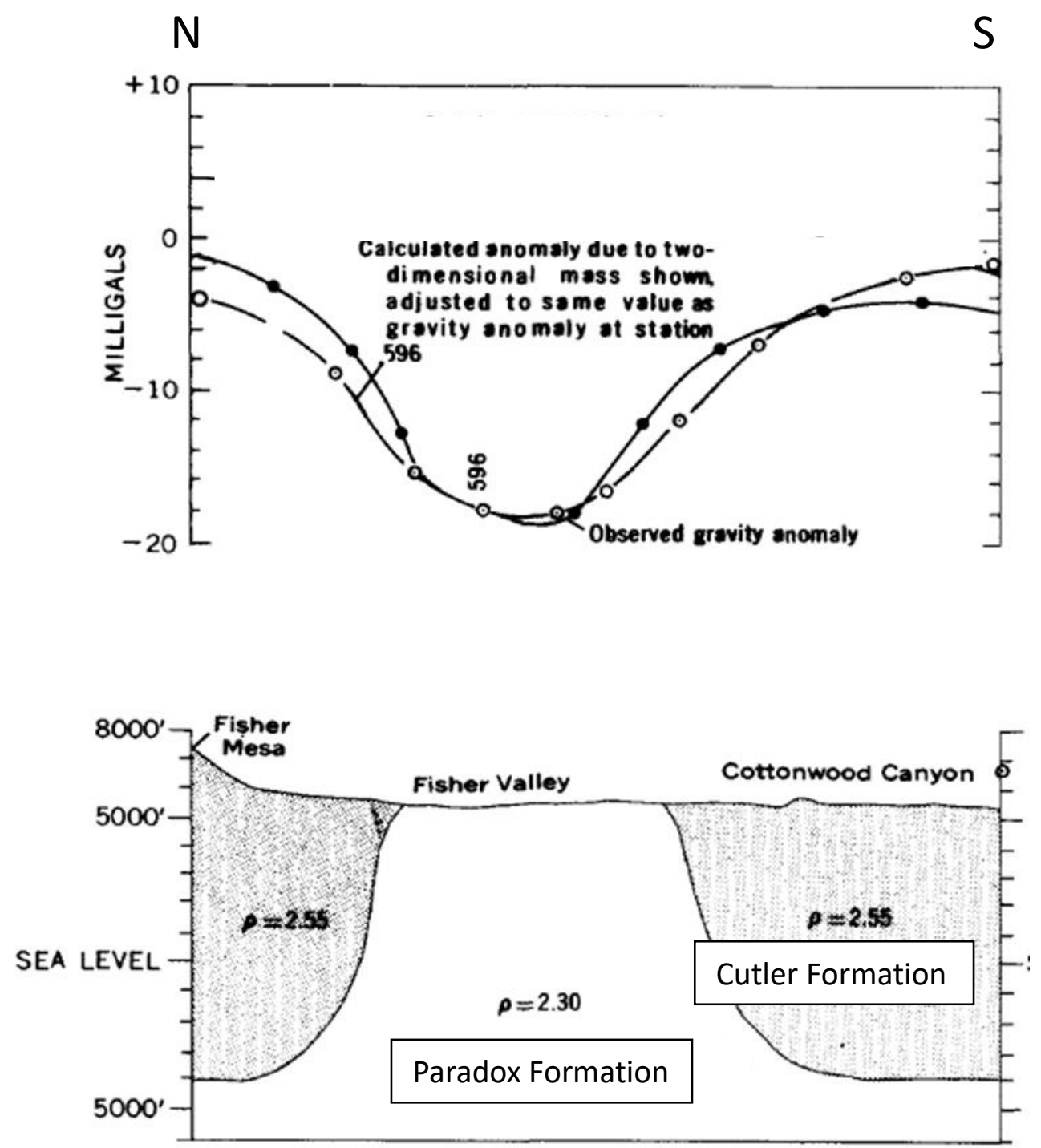

Figure 12: Top: A gravity profile over the Fisher Valley salt diapir. The calculated anomaly matches the observed anomaly to within 2-3 mGal. A drop of nearly $20 \mathrm{mGal}$ is seen over the salt body. Bottom: A generalized model of the salt diapir at Fisher Valley with the Paradox Formation given a density of $2.30 \mathrm{~g} / \mathrm{cm}^{3}$, a value that would include some clastic rocks and not just pure salt. The sediments surrounding the body are from the Cutler Formation with a density of $2.55 \mathrm{~g} / \mathrm{cm}^{3}$ (modified from Case and Joesting 1972). 


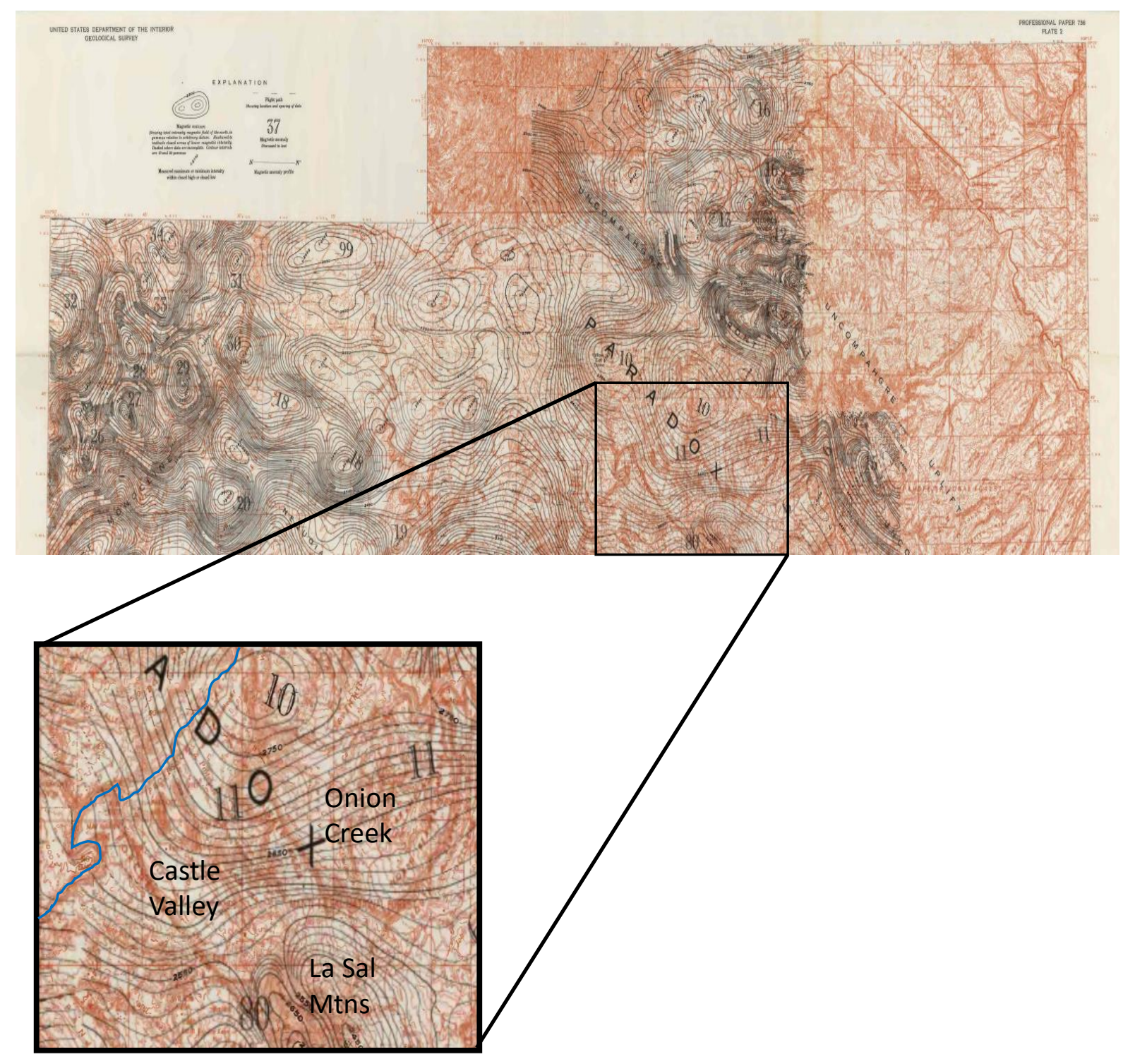

Figure 13: Magnetics map from the entire Paradox basin. A continuously recording fluxgate magnetometer was used mounted to a fixed wing aircraft. A zoomed in look of the study area shows no major magnetic anomalies associated with the salt due to the standard error of the instrument $\pm 5 \mathrm{nT}$ and sensitivity of aeromagnetic techniques to longer wavelength, deeper bedrock structures. The Colorado River is highlighted in blue and the major locations of the field area were labeled (modified from Case and Joesting 1972). 

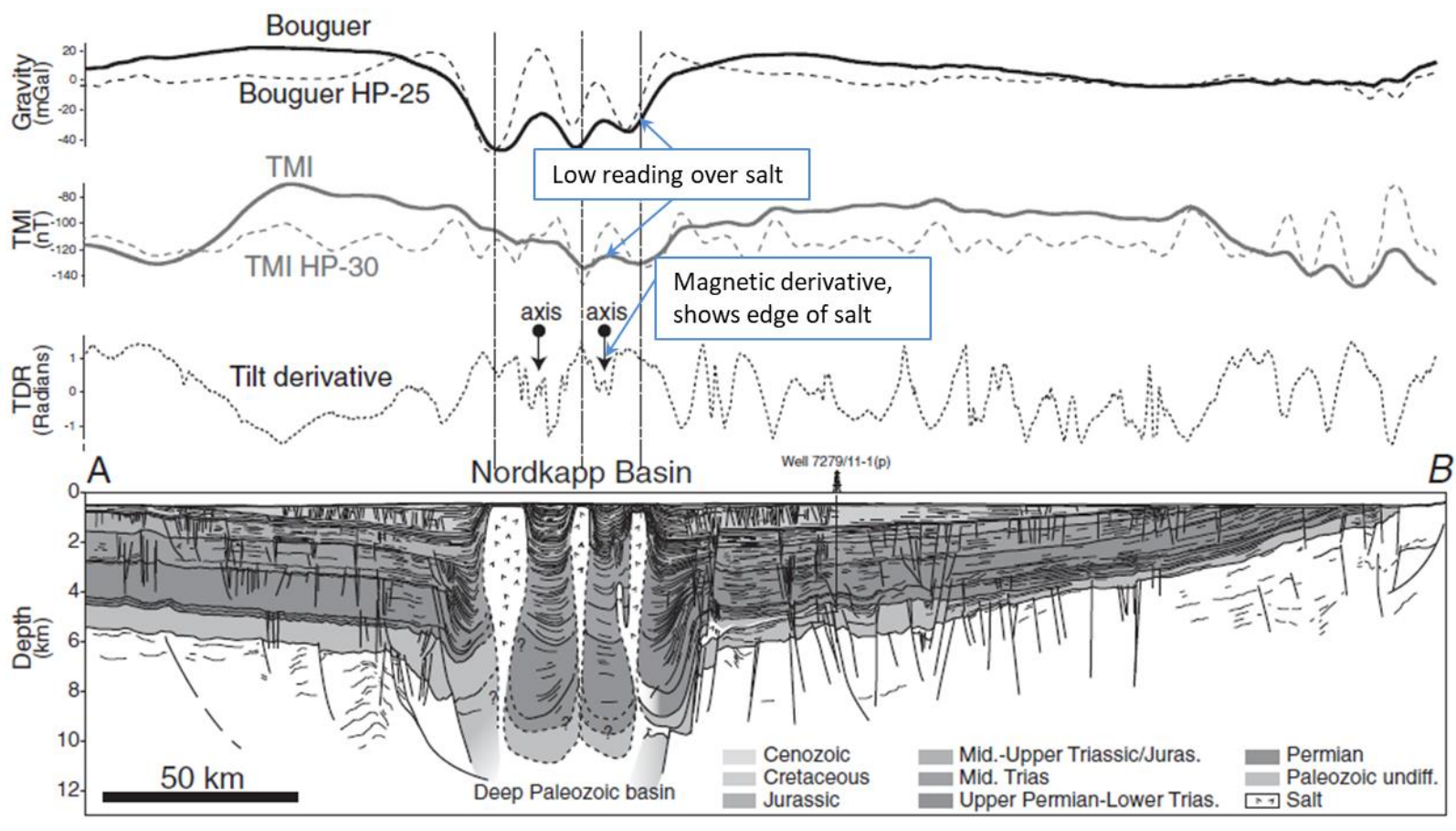

Figure 14: Top: Bouguer Gravity Anomaly in mGal over the Nordkapp Basin salt diapirs. A distinct low can be seen over the salt structures. Middle: Total Magnetic Intensity in nT from a high resolution aeromagnetics survey. Note the lows over the salt diapirs which are distinctly diamagnetic. Bottom: A tilt derivative plot in radians. This helps to distinguish the edge of salt at the areas with the greatest derivative values. A to B is a cross section for the above profiles containing a well for some stratigraphic control. This method, at a finer scale, may be able to distinguish the antiforms and synforms of the Cutler Formation (modified from Gernigon et al 2011). 


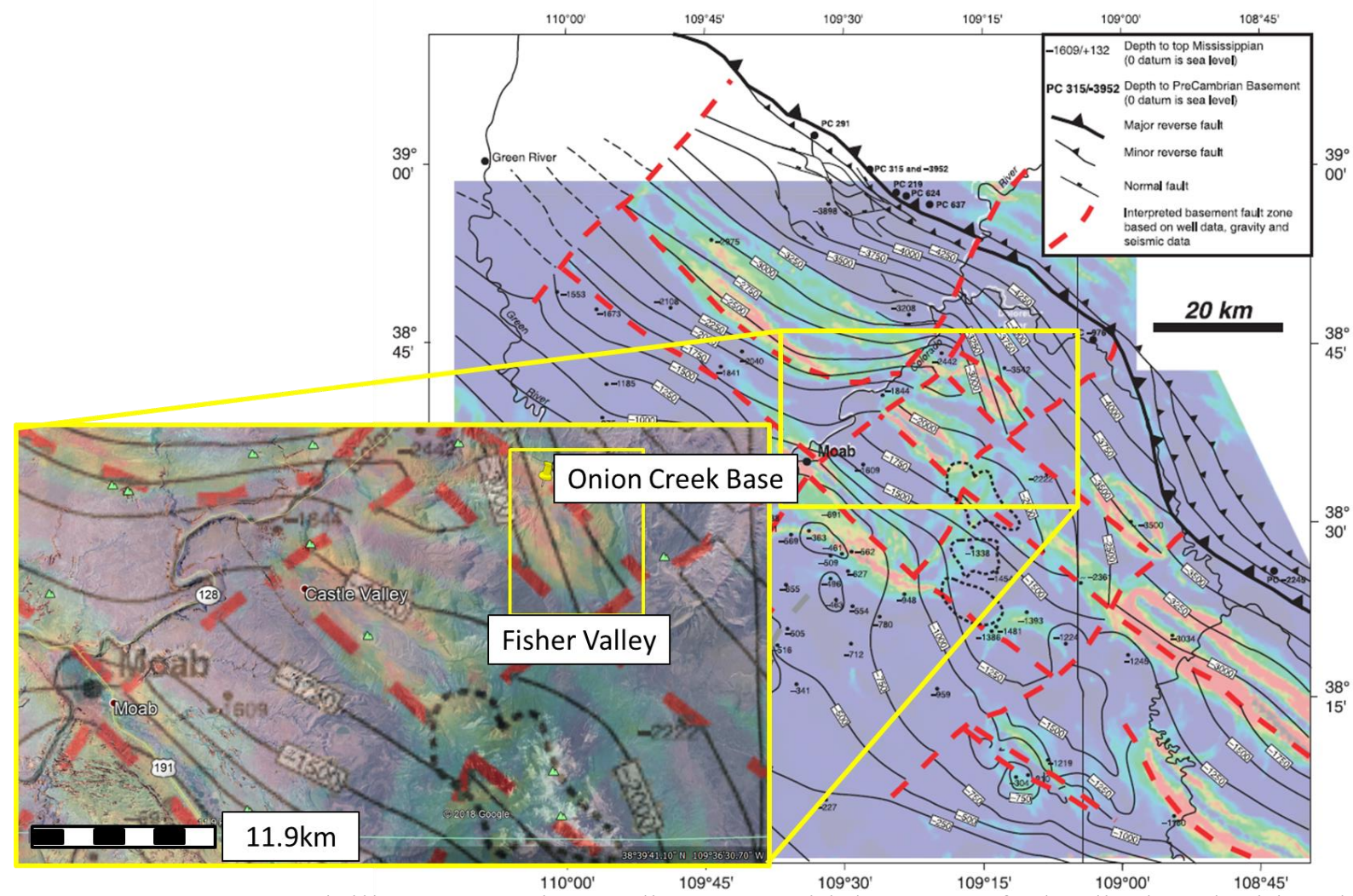

Figure 15: From Trudgill 2011, gravity gradient map with basement faults displayed with red dashed lines. This map helps to support the presence of salt throughout Fisher Valley, adjacent to the exposed Onion Creek salt diapir. Pop-out map from Google Earth that boldly displays the red and yellow colors that indicate a large change in the gravity signature, the edge of salt. 


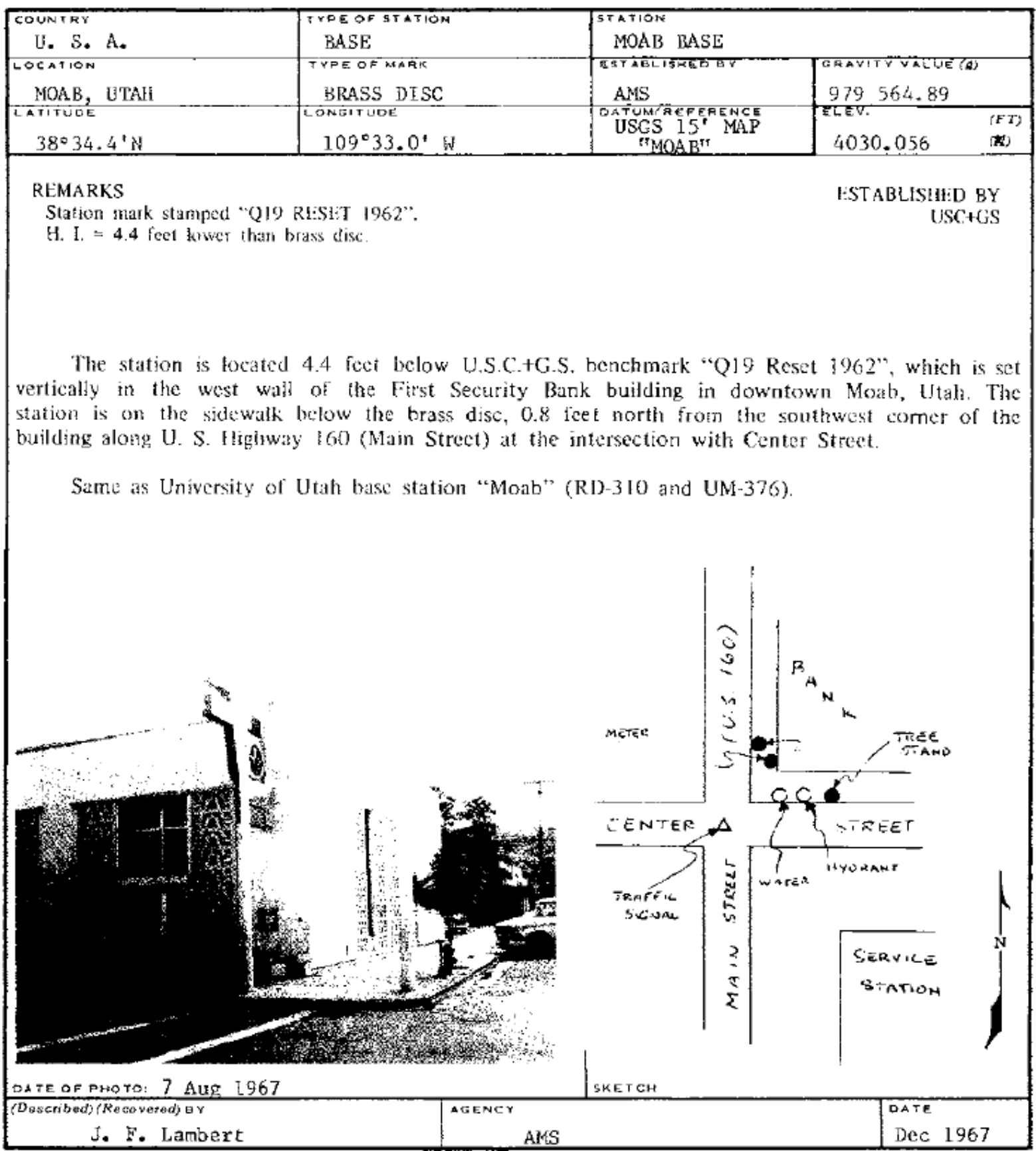

Figure 16: Moab Absolute base established in Dec 1967 which is the basis for both the Castle Valley and Fisher Valley gravity base stations (From Cook et al. 1971). 


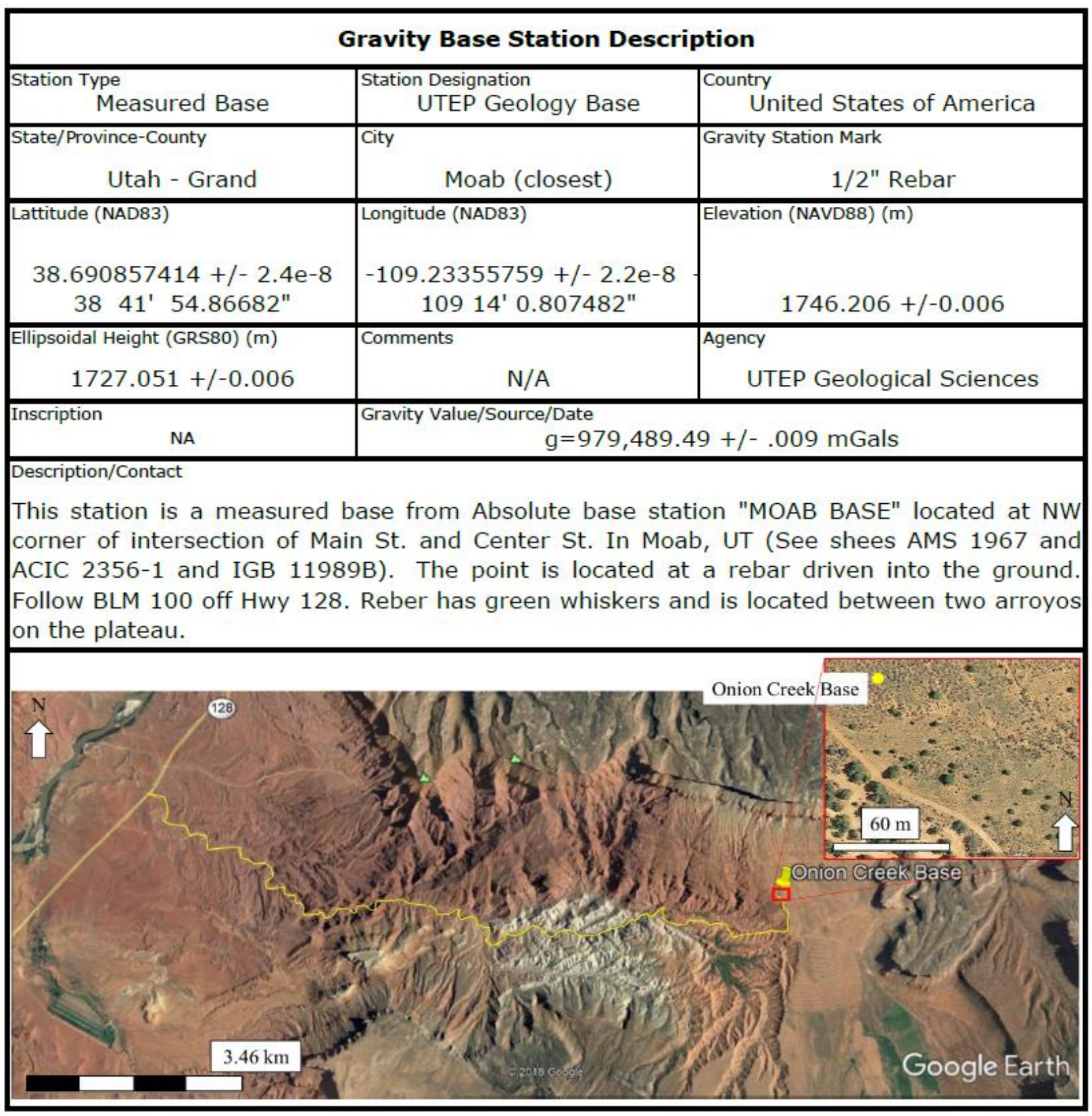

Figure 17: Fisher Valley/Onion Creek Gravity Base Station Datasheet. The absolute base used was located in Moab, however, the Onion Creek base was established via the Castle Valley base established in November 2018. 


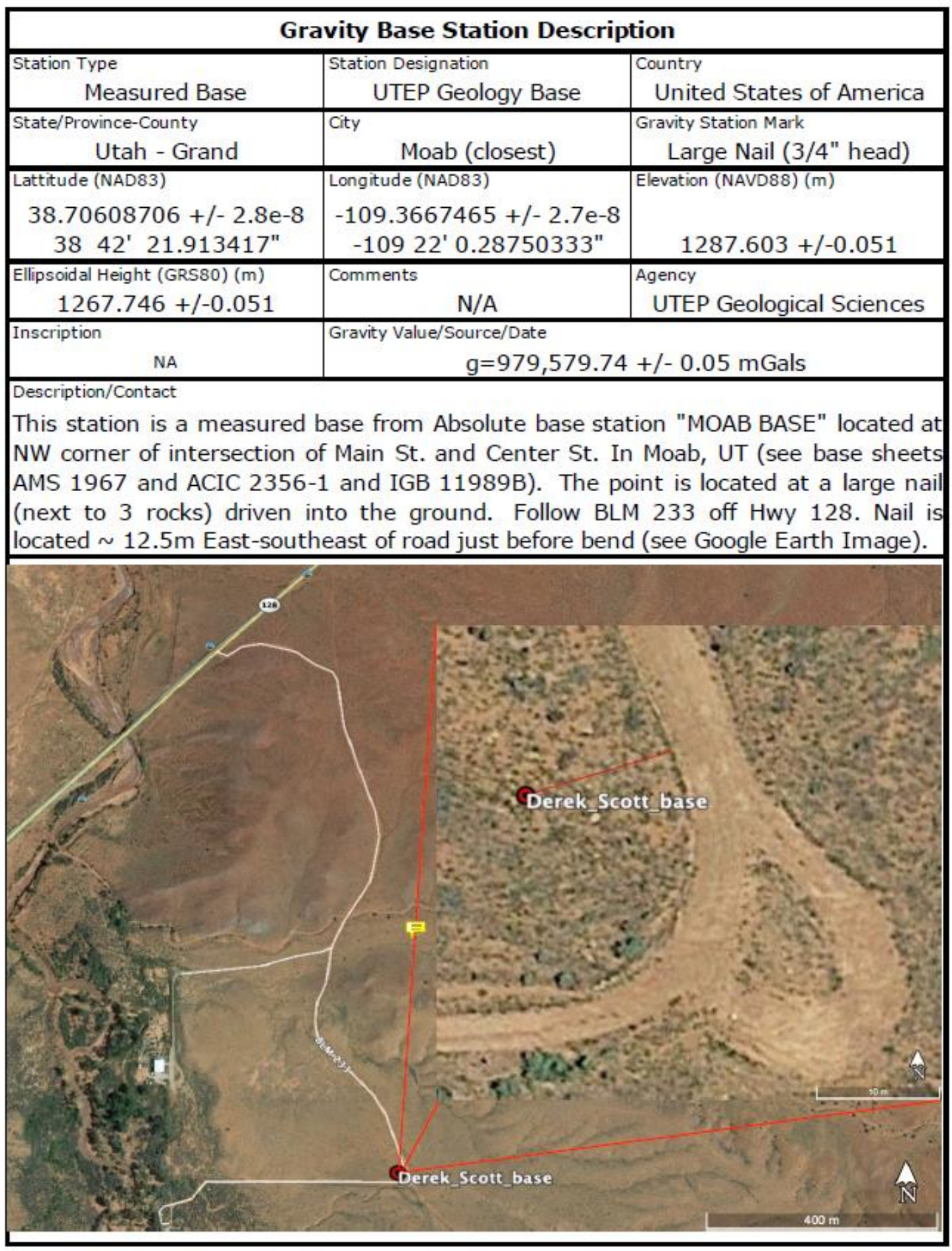

Figure 18: Base Station established by Derek Scott in Castle Valley from the Moab absolute base. Once an absolute gravity number was established here, I used this station to establish my own base station in Fisher Valley/Onion Creek. 


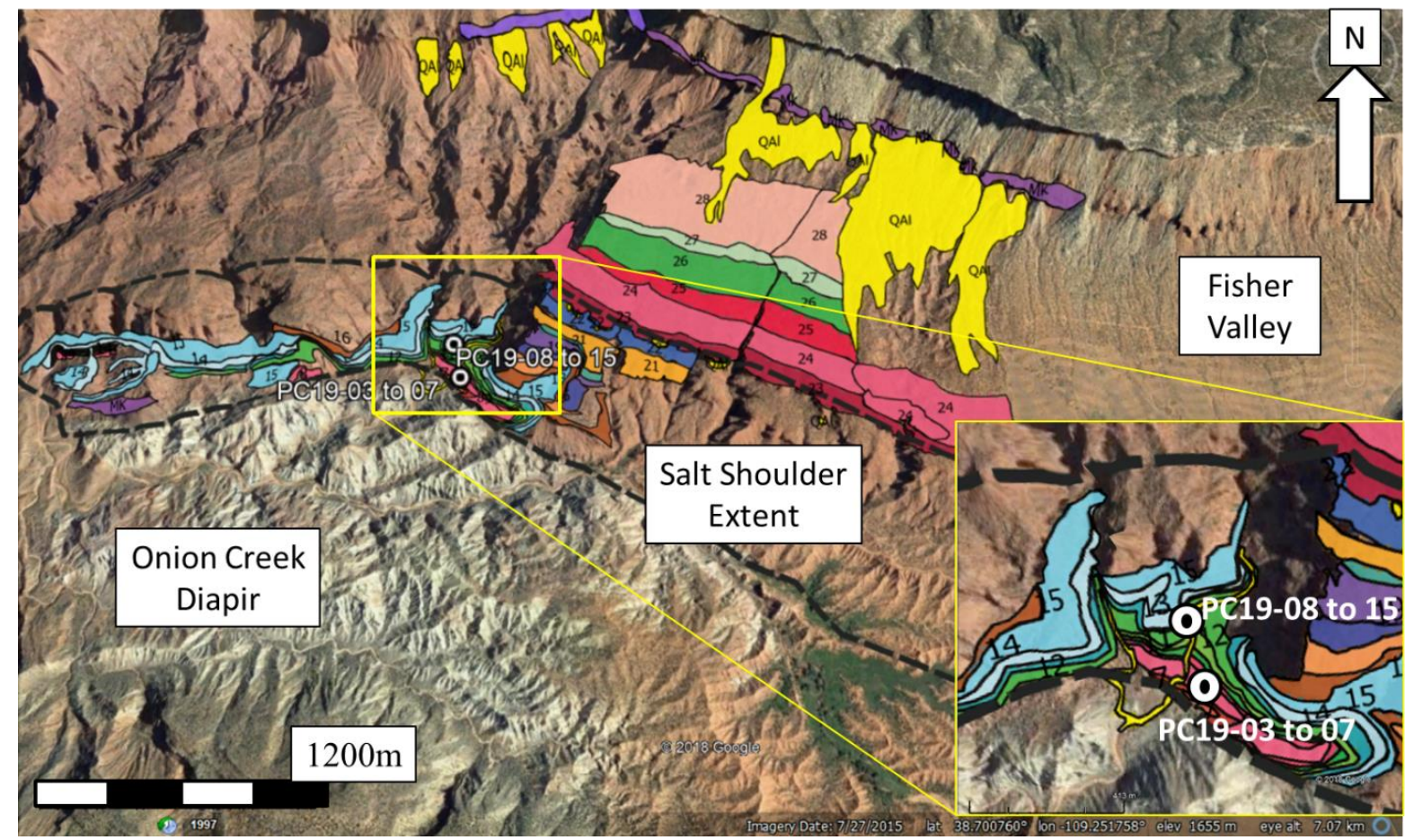

Figure 19: A geologic map of the divisions of the Permian Cutler Unit (PC19-03 to 15). White/black circles represent approximate locations of sample collection sites. These rocks were measured for density and magnetic susceptibility. The black dashed line represents the extent of the salt shoulder via measured sections (modified from Lankford-Bravo 2019). Table 1 depicts the density and magnetic susceptibility values of these units. 


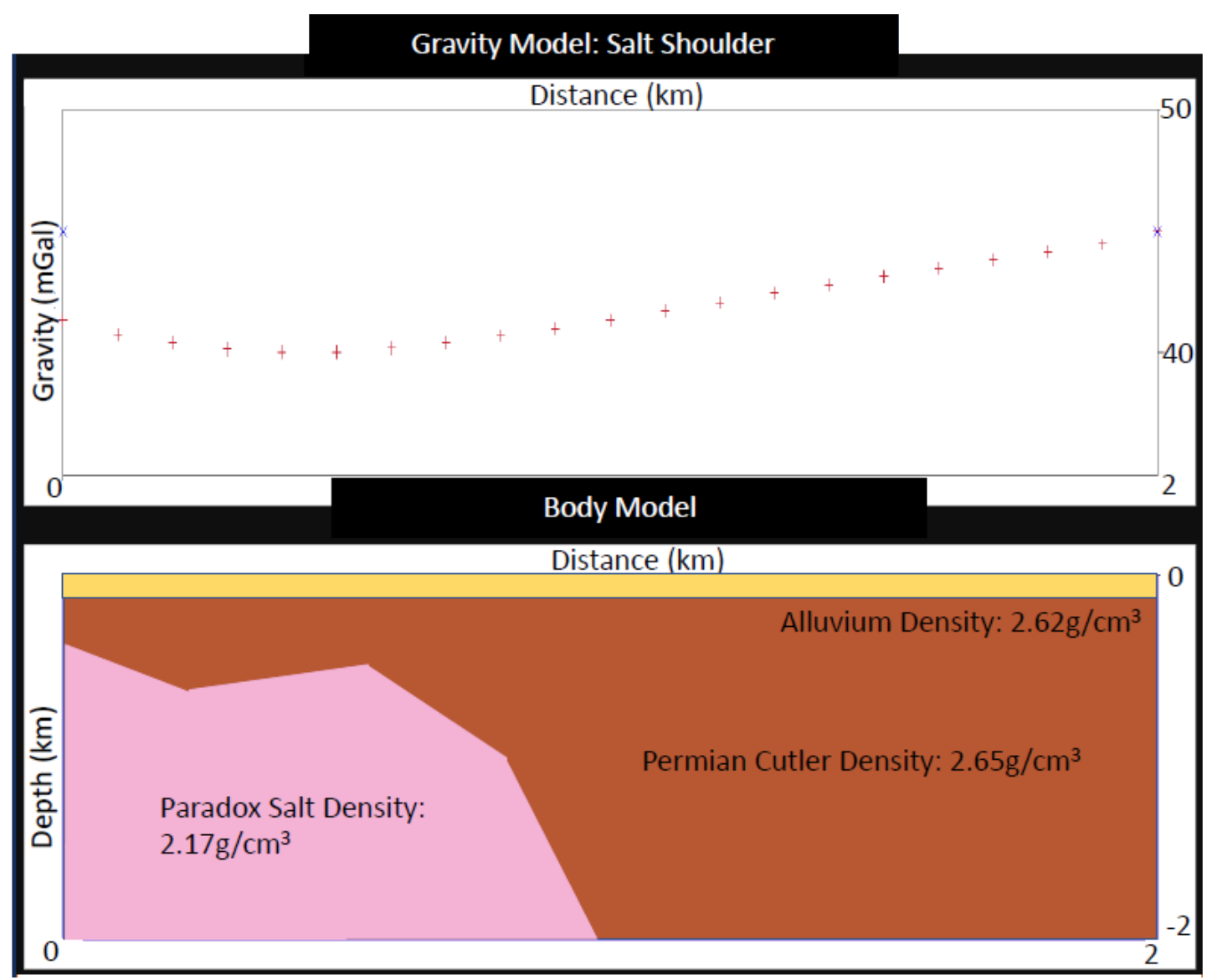

Figure 20: An early forward model testing the Onion Creek salt shoulder hypothesis. Yellow represents alluvium, red is the Permian Cutler, and pink is the Paradox salt, all with differing densities. A gravity low is seen over the diapir and the salt shoulder with a variation of up to $7 \mathrm{mGal}$, a significant change (Talwani et al. 1959; and Cady 1980). It was found this software was not adequate for later modeling processes once the gravity data were collected. 


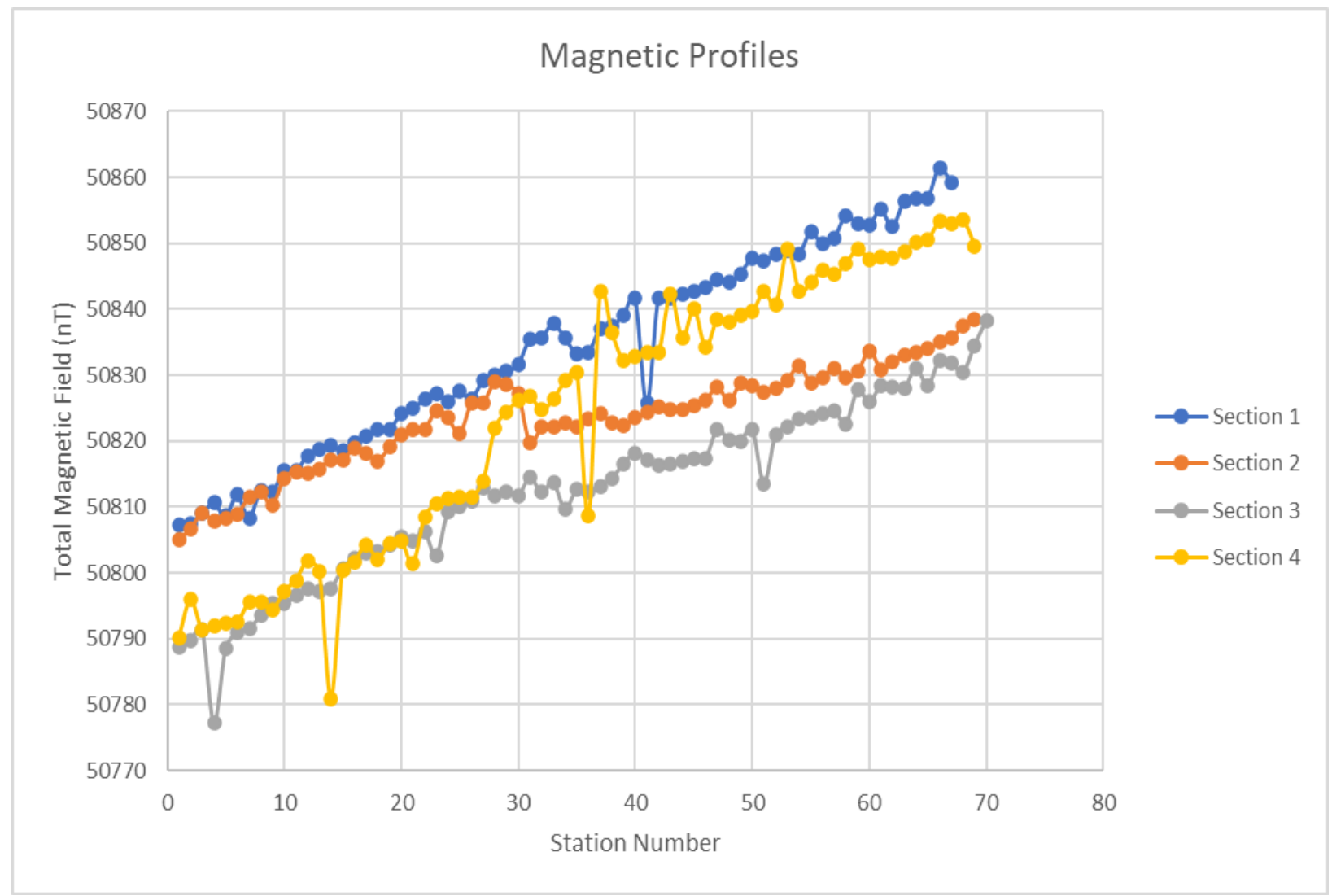

Figure 21: Magnetic Profiles with Section 1 located furthest to the west and Section 4 furthest to the east on the Fisher Valley Plateau. It is not immediately clear where the edge of salt would be located based on these data. See Figure 24 for profile locations. 


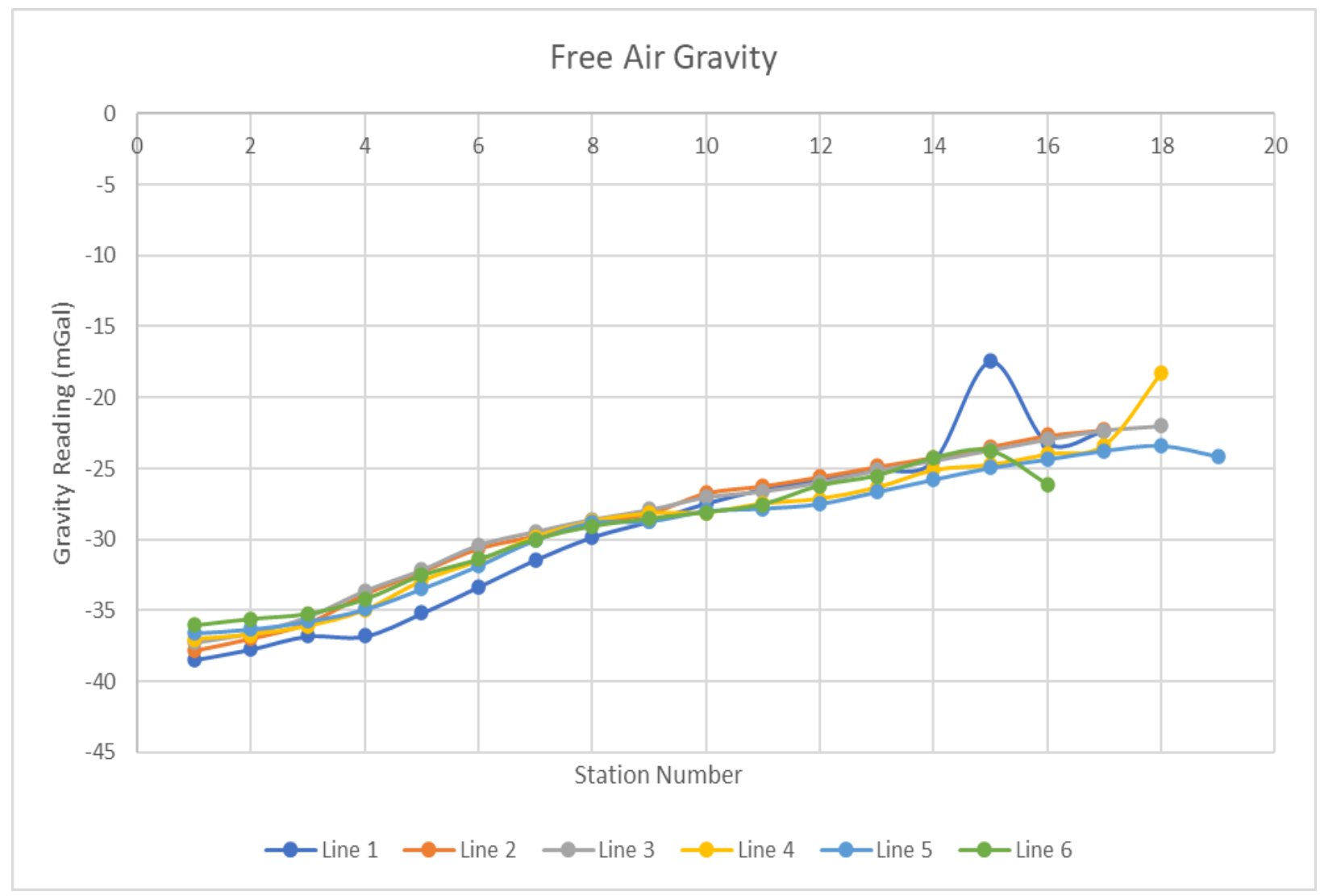

Figure 22: Free Air gravity profiles with Line 1 located furthest to the west and line 6 furthest to the east. Between stations 4-8 there is a change in slope of these profiles which may indicate the edge of salt within that region. See Figure 23 for profile locations. 


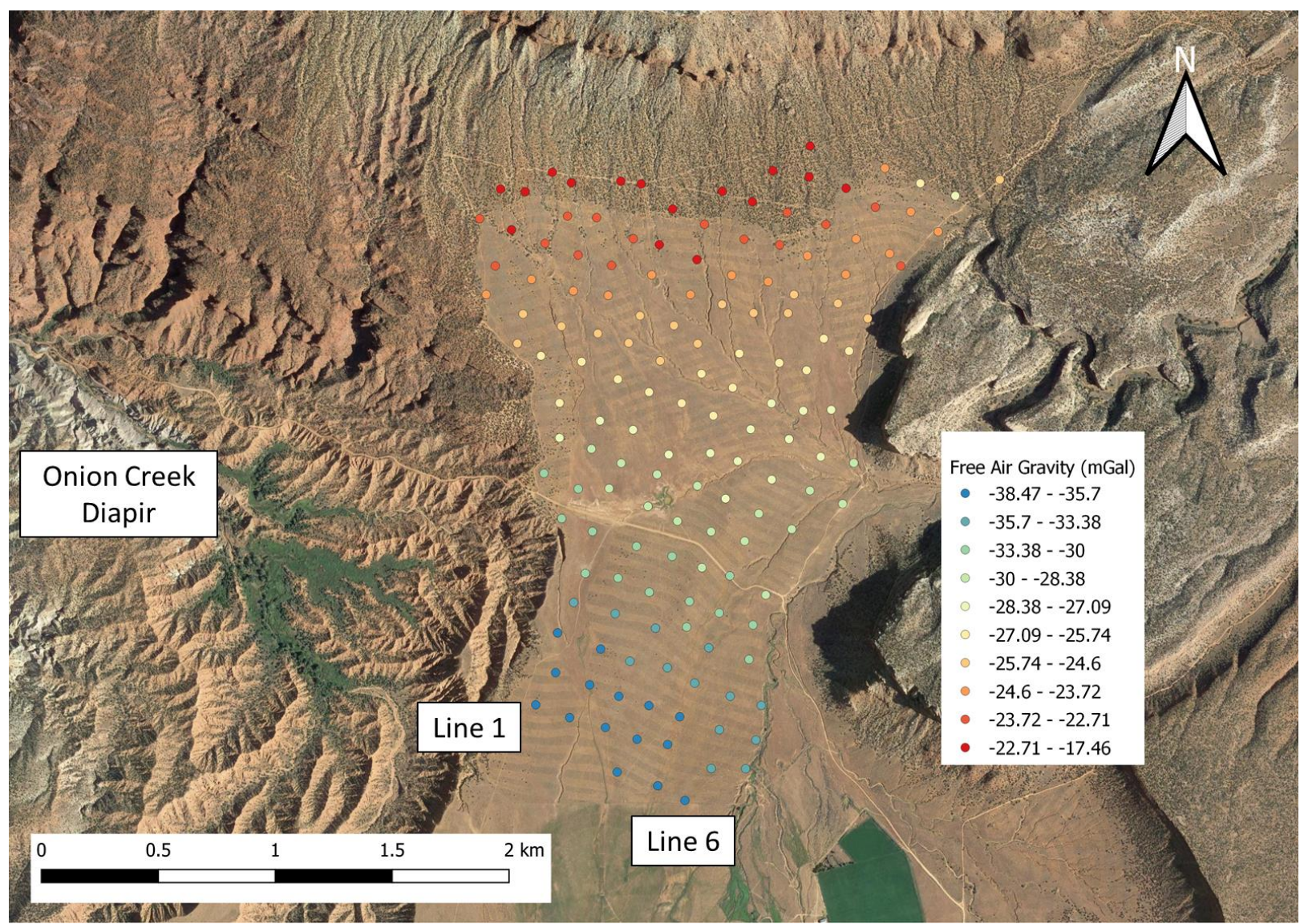

Figure 23: Free Air gravity gridded across Fisher Valley. This includes only the data collected for this study. Notice the lower gravity readings to the south where the exposed salt wall can be seen off to the west side. 


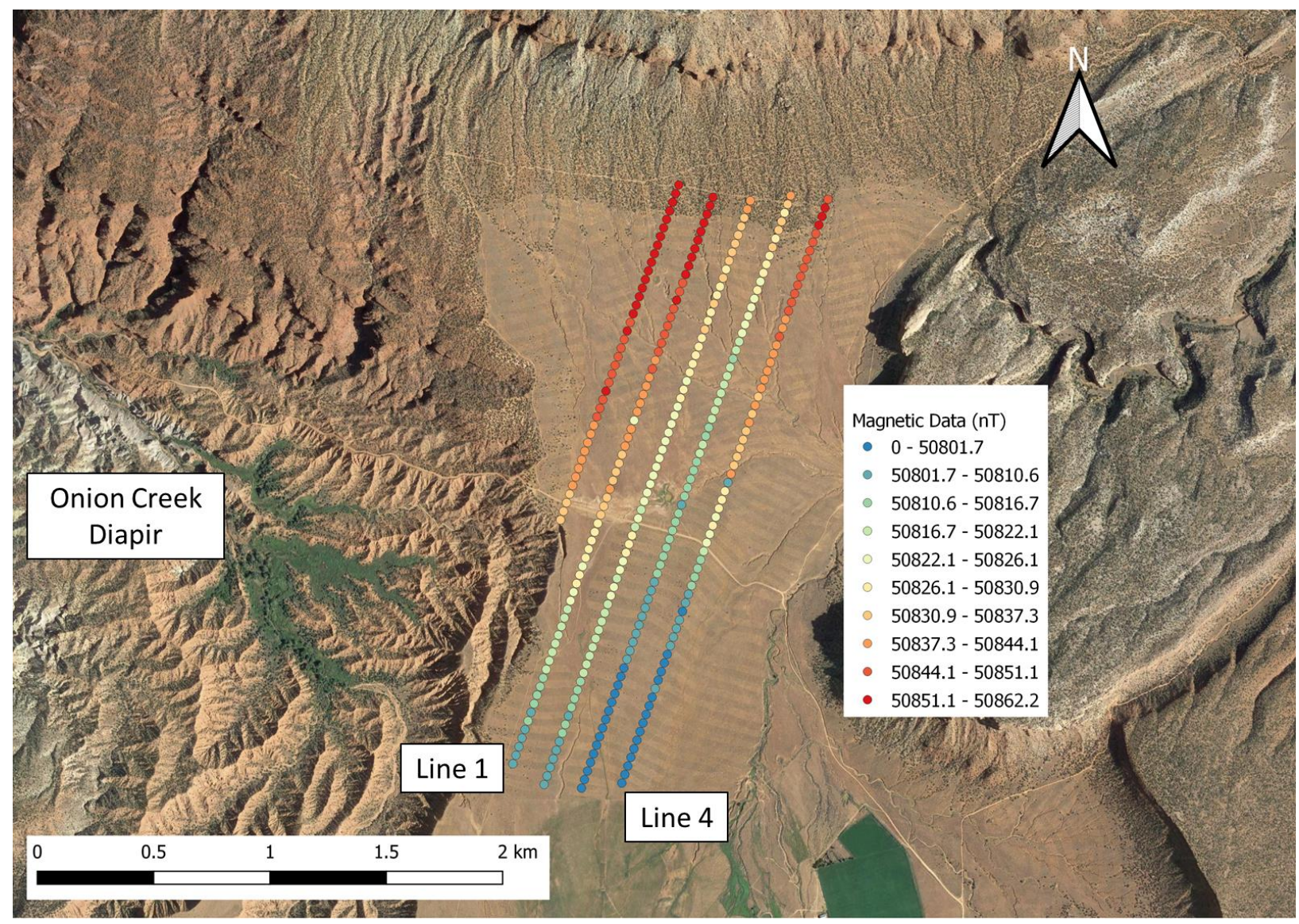

Figure 24: Magnetic ground survey run across Fisher Valley. Notice these readings mimic the gravity with lower readings on the south side and higher readings to the north. 


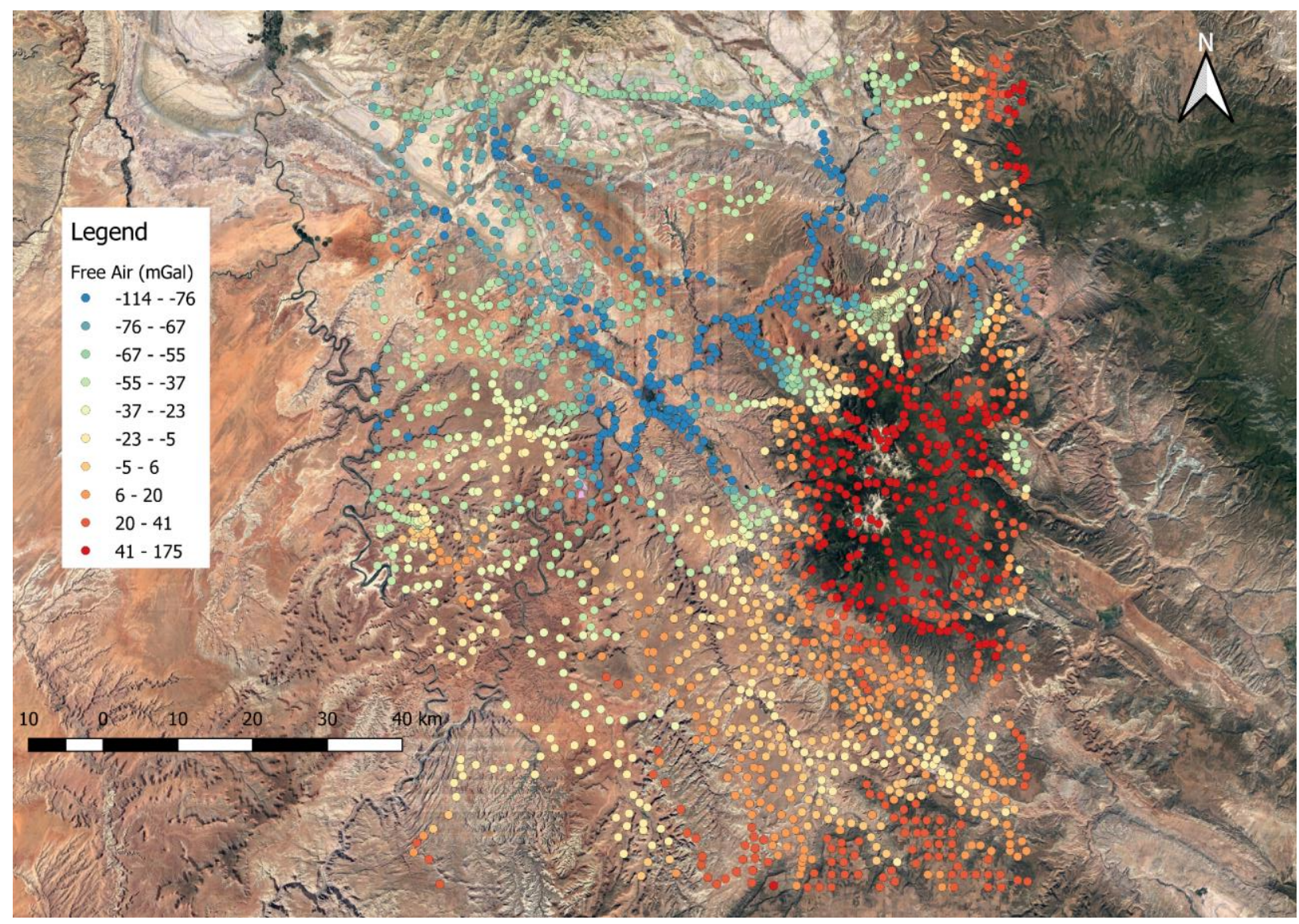

Figure 25: Free Air PACES gravity data with Onion Creek data included. Data were determined to come from the Case and Joesting 1972 gravity survey. Higher gravity is seen over areas of higher density, such as volcanic rock of the La Sal Mountain Complex. Lower gravity can be seen over known salt walls in the region such as Fisher Valley or Castle Valley. 


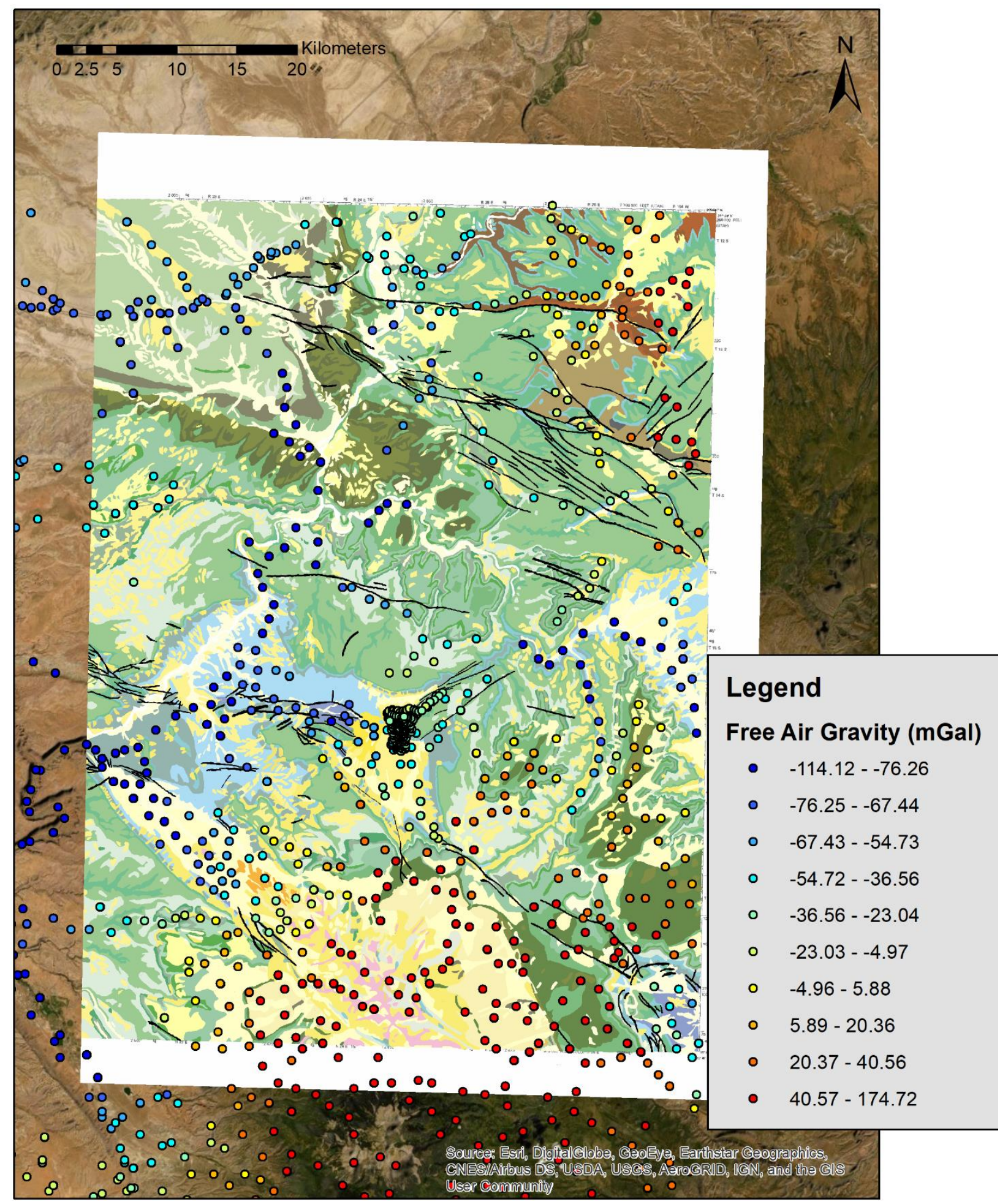

Figure 26: Free Air PACES and Onion Creek survey data with modified Doelling2002b geology map georeferenced to the satellite view. Trends in the gravity can be seen correlating to the salt walls (low/blue) and volcanic intrusions (high/red) in the area. 


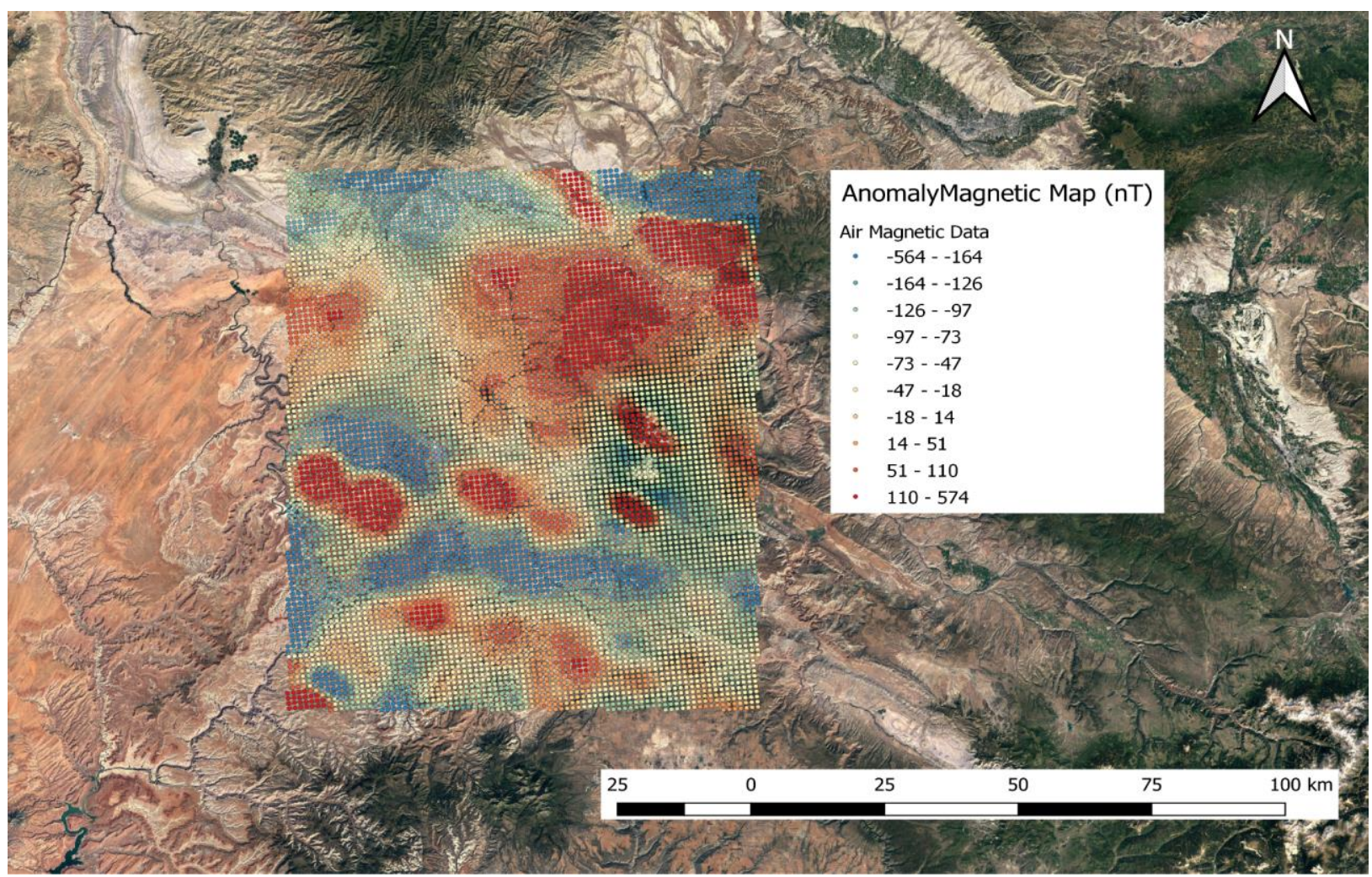

Figure 27: Aerial magnetic data from the PACES server for the northern part of the Paradox Basin. This aerial data is a bit more ambiguous on location of salt walls in the Paradox Basin and appears to be more closely related to higher magnetic signatures of the various larger volcanic intrusion complexes. 


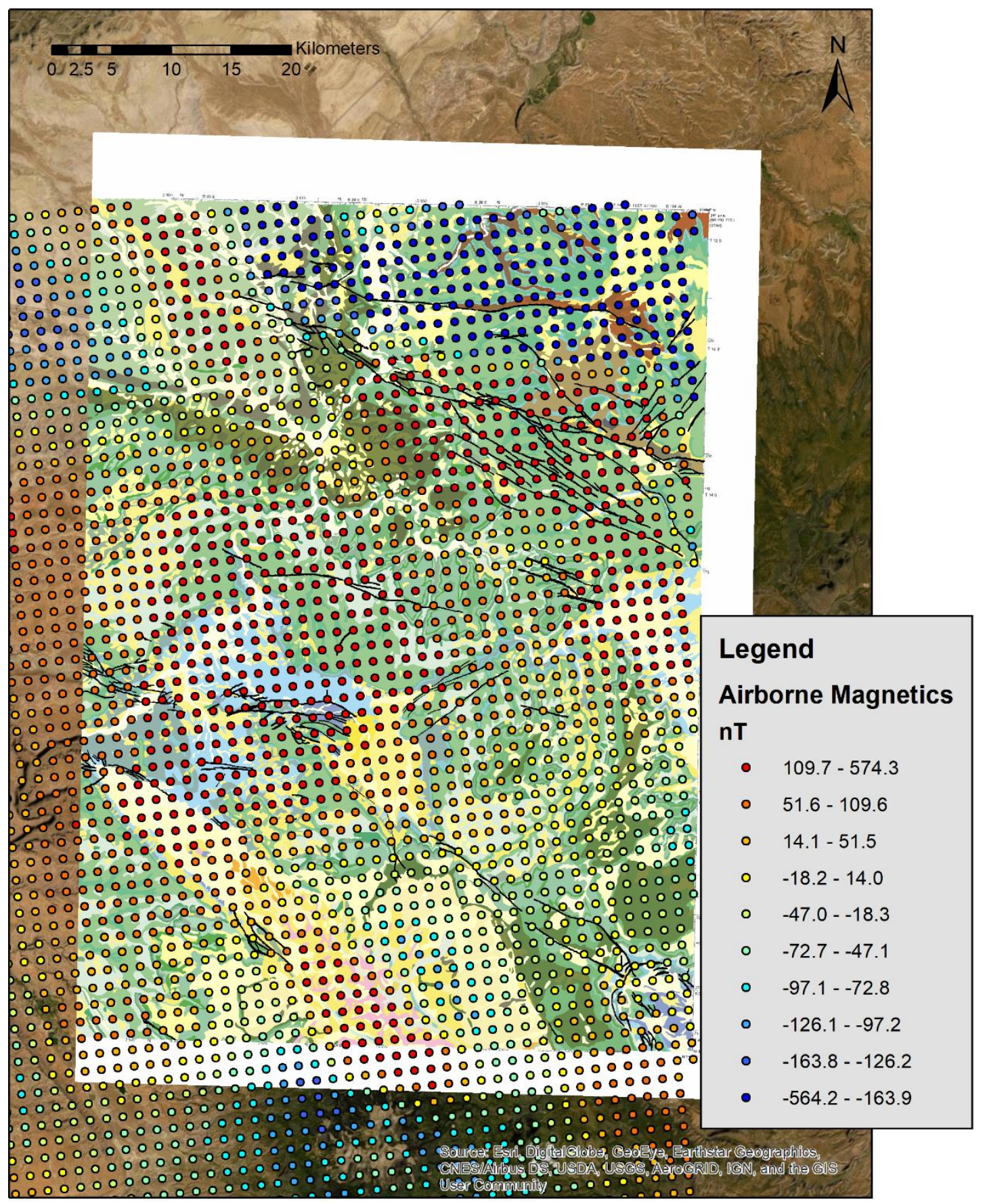

Figure 28: Aerial magnetic data overlain onto the modified Doelling (2002b) map. No clear trend can be seen at Onion Creek. The nearby La Sal Mountains are volcanic and appear as a magnetic high. 


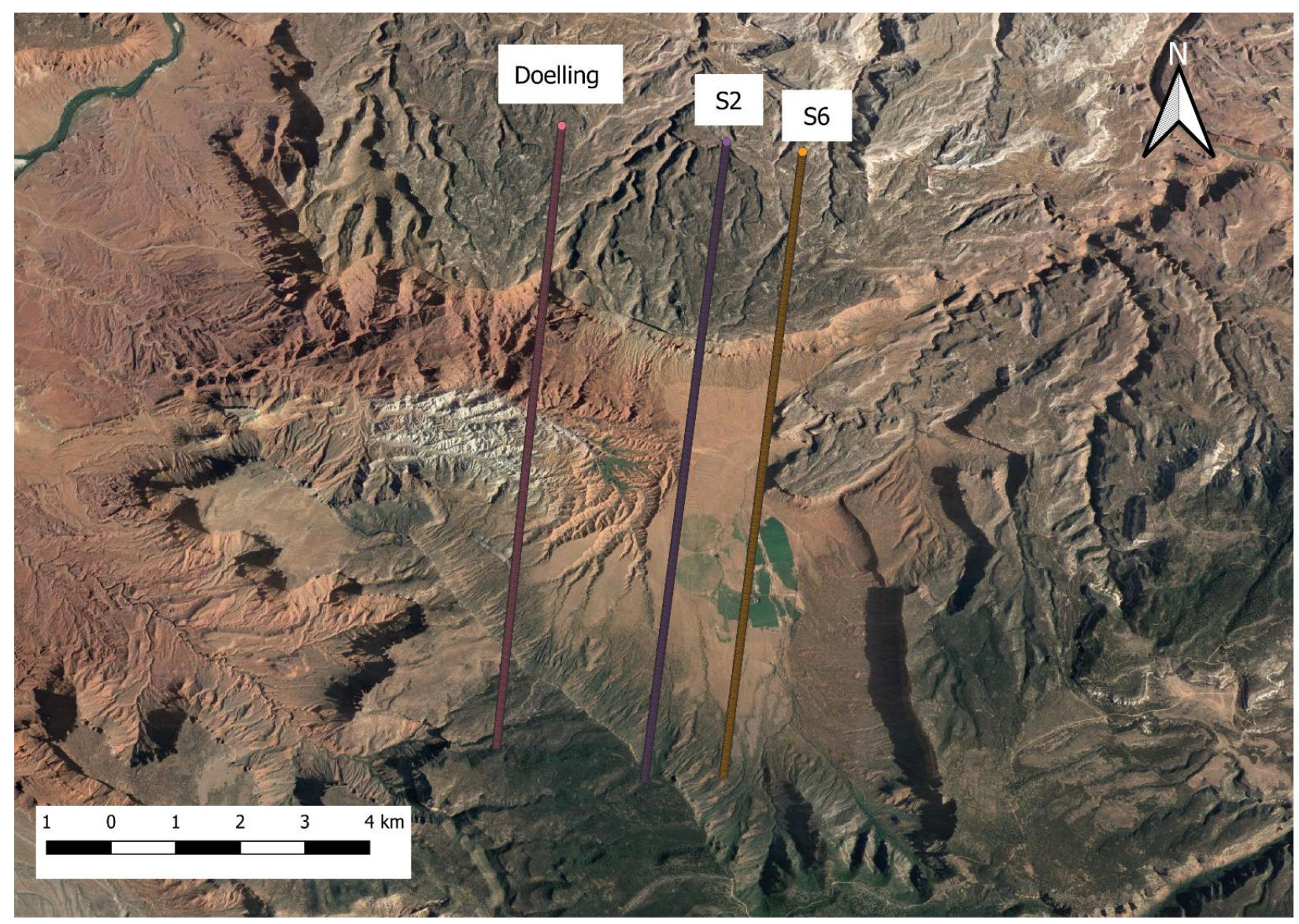

Figure 29: Cross sections in the region of Onion Creek. The pink line represents where the Doelling cross section was drawn. The purple S2 cross section includes both gravity and magnetic models (forward and inverse). The orange S6 profile includes a gravity profile only (forward and inverse). 

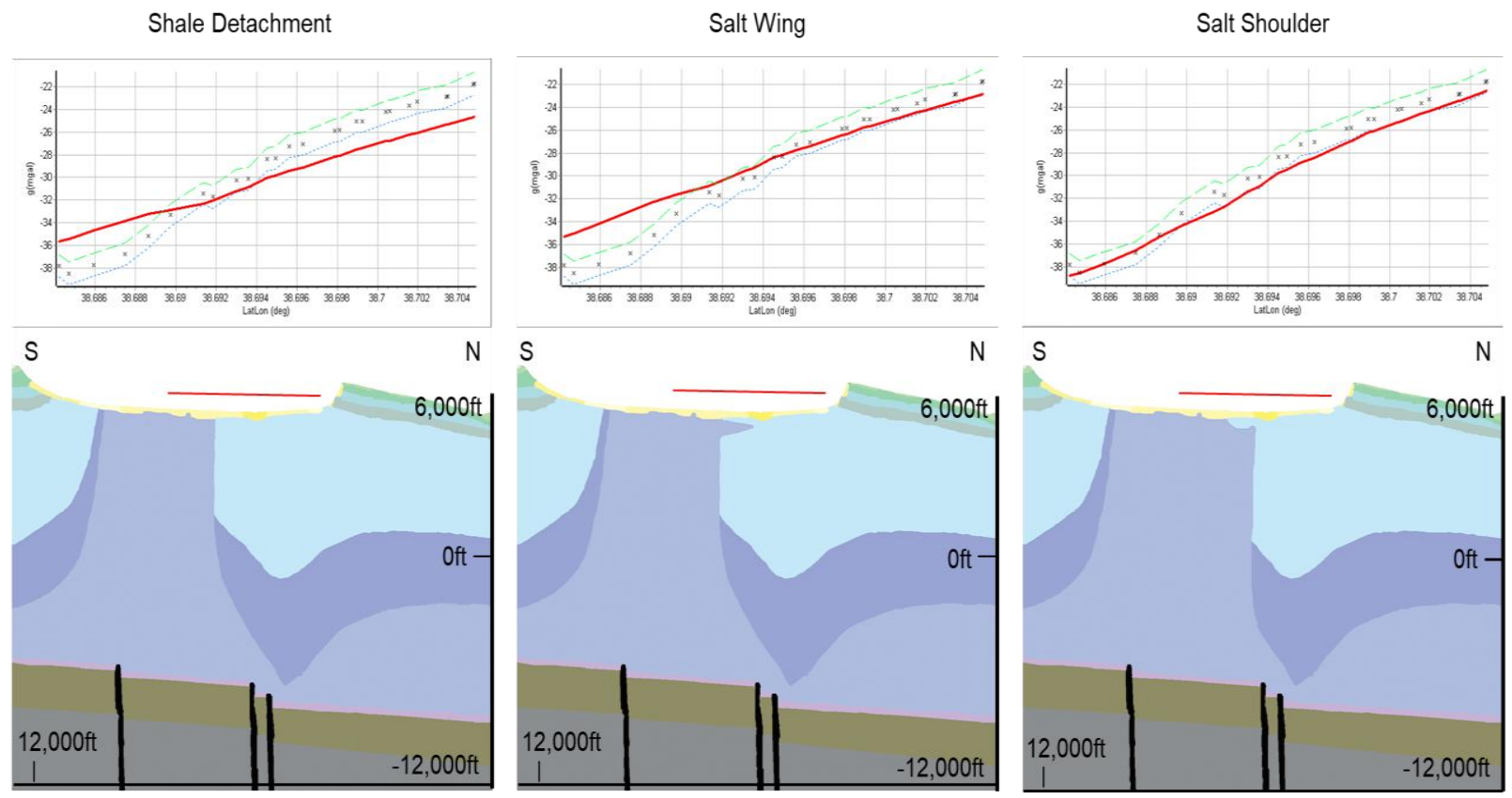

Figure 30: Three salt structure scenarios generated within DemGeoElev and DrawSection. These sections were then forward modeled in Gravity2DSurf. Color representing each geologic unit is taken from Doelling's (2002b) map. The red line is the predicted curve based on the density table and cross section. The black X's are the observed Free Air gravity readings. The green and blue lines represent error bounds. The red line over each cross section shows where the observed gravity readings are present. Densities are found in Table 2. 


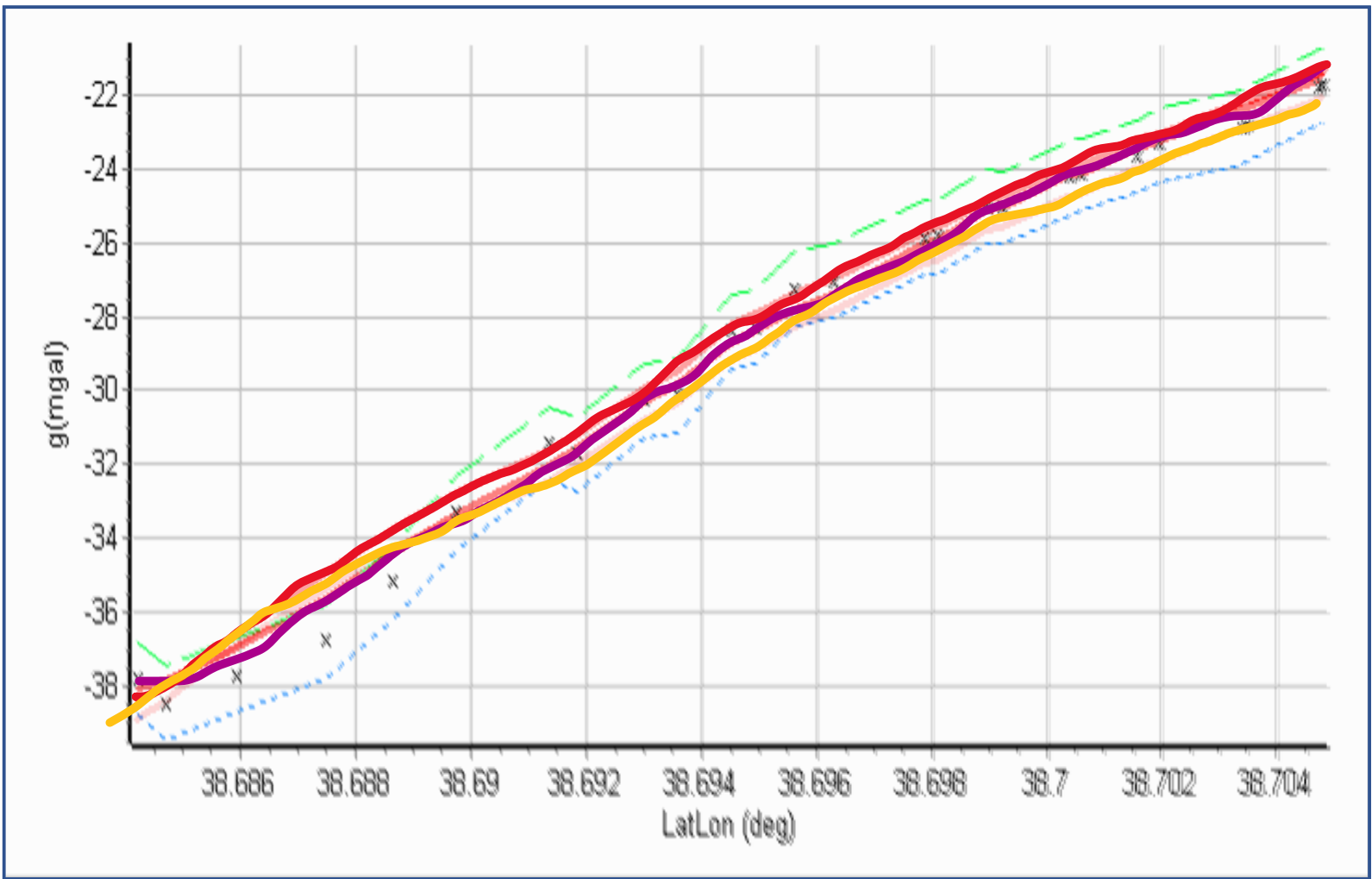

Figure 31: S2 Gravity inversions, orange: shale detachment, red: salt wing, purple: salt shoulder. Shoulder model still has the closest fit, but all models overestimate observed gravity on the south side of the profile. Density results from inversion found in Table 3. 

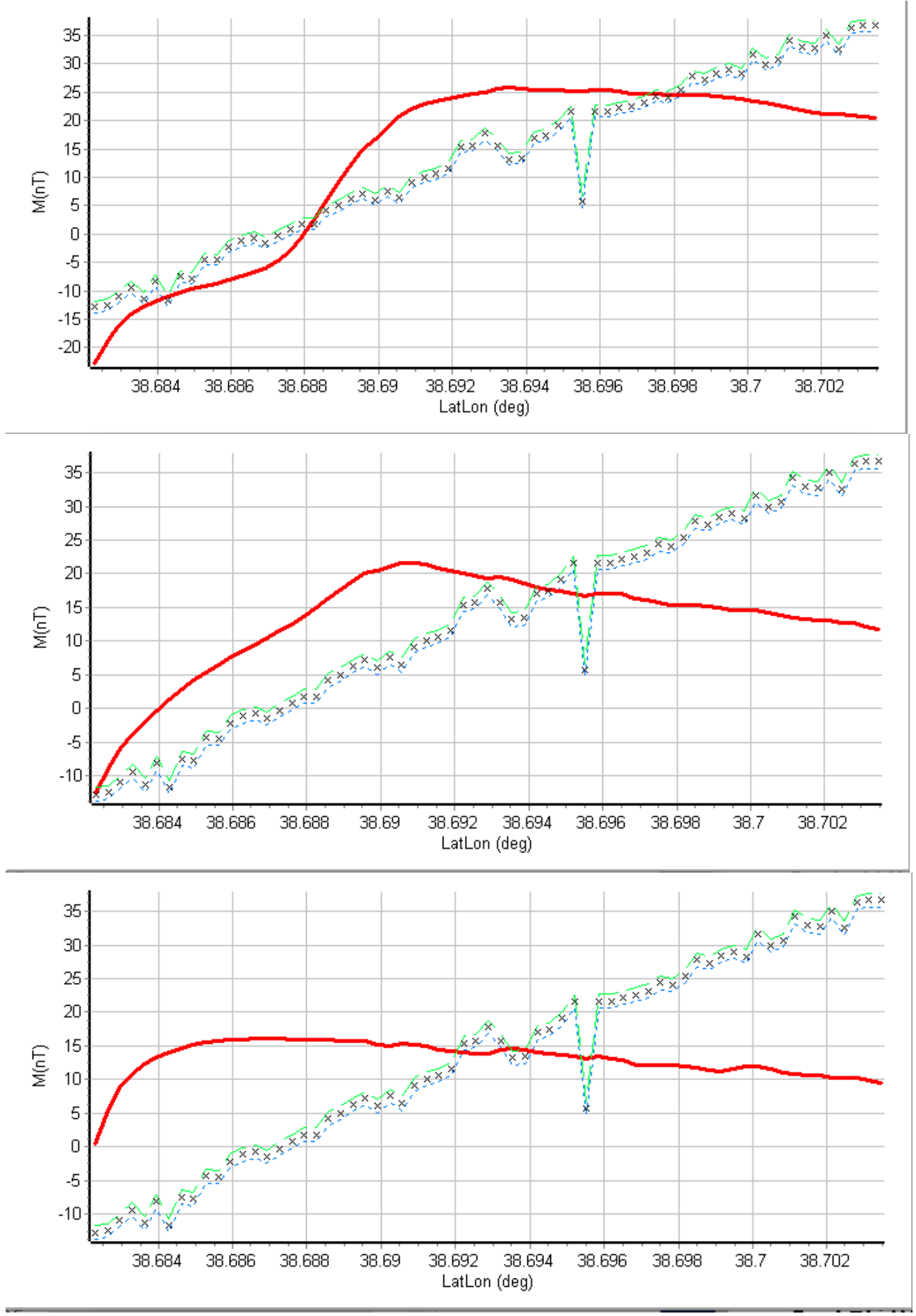

Figure 32: Magnetic Forward Models, Top: salt shoulder, RMS: 8.47, Middle: salt wing, RMS: 12.41, Bottom: shale detachment, RMS: 15.83. Susceptibility values are given in Table 4. Cross sections are identical to the S2 gravity profiles. Red is predicted magnetics, X's are observed. 

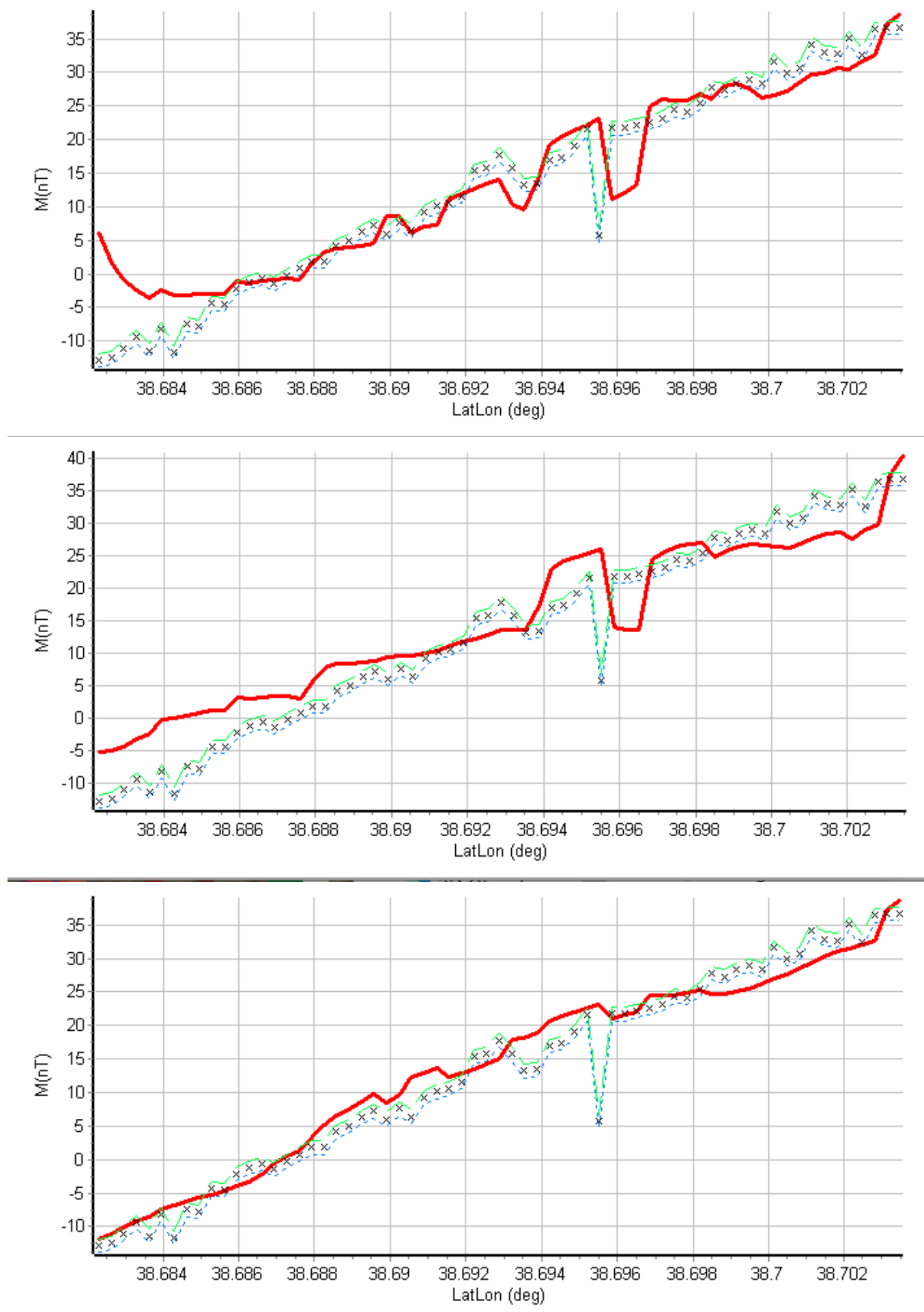

Figure 33: Inversion results for magnetic models. Top: Shale Detachment, Middle: Salt Wing, Bottom: Salt shoulder. Susceptibilities from inversion given in Table 5. 

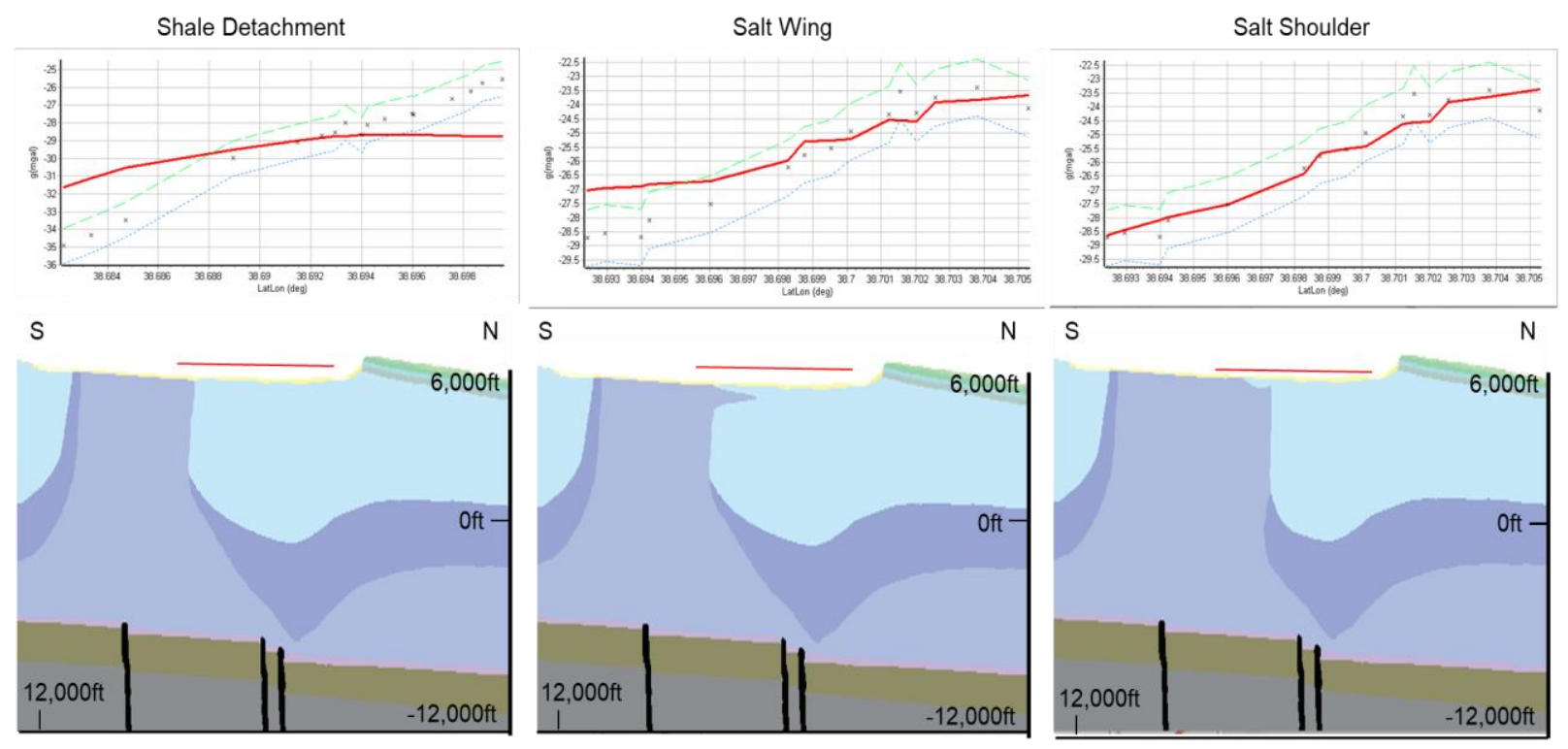

Figure 34: S6 profile. Three salt structure scenarios generated within DemGeoElev and DrawSection. These sections were then forward modeled in Gravity2DSurf. Color representing each geologic unit is taken from Doelling (2002b) map. The red line is the predicted values from the density table (Table 6) and cross section. The black X's are the observed Free Air gravity readings. The green and blue lines represent the margin of error. The red line over each cross section shows where the observed gravity readings are present. Shale Detachment RMS: 2.01, Salt Wing RMS: 0.96, Salt Shoulder RMS: 0.43 . 

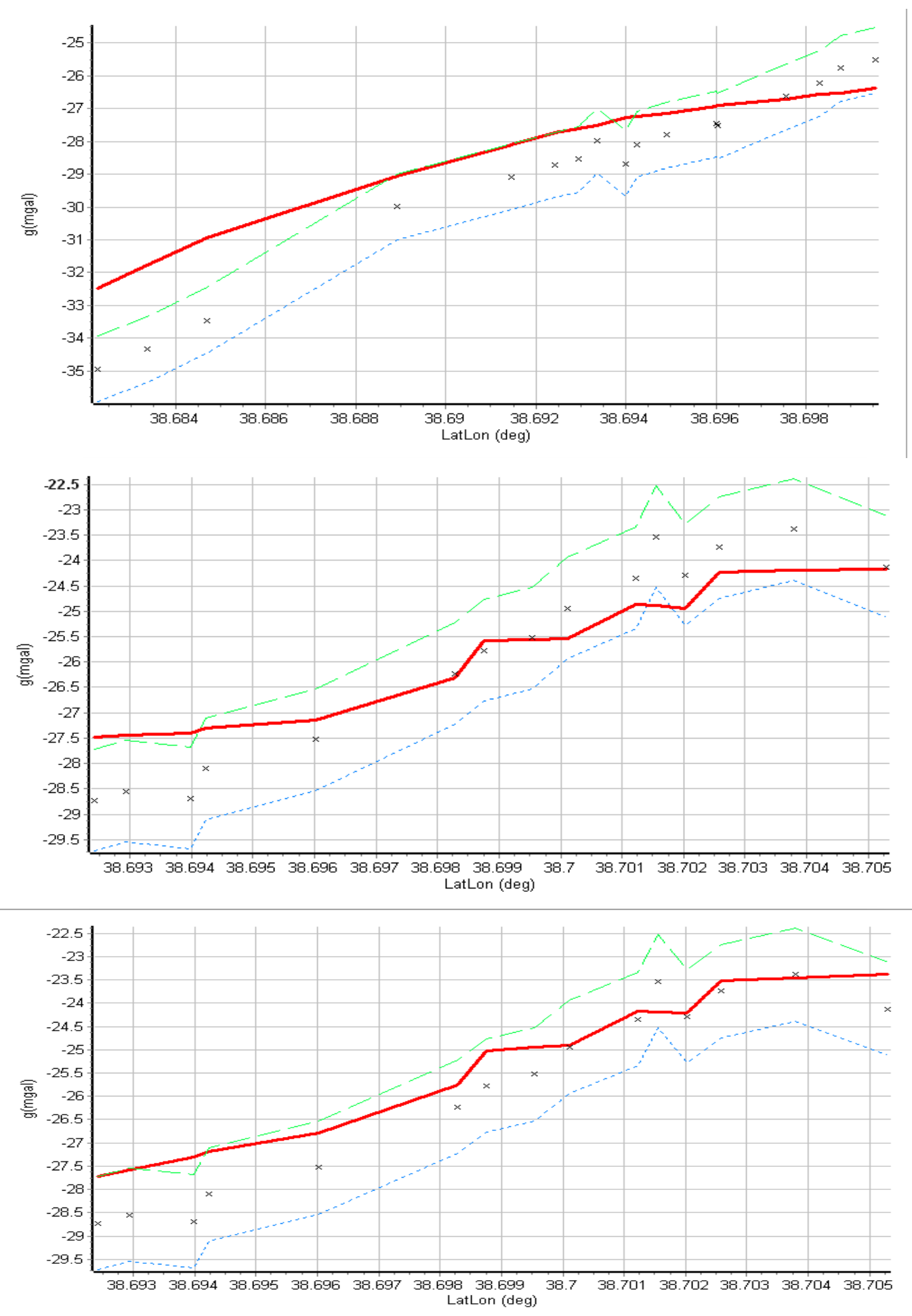

Figure 35: S6 profile for gravity forward models. Top: Shale Detachment, RMS: 1.33, Middle: Salt Wing, RMS: 0.8, Bottom: Salt Shoulder, RMS: 0.73. 


\section{REFERENCES}

Amador, C.M., Miller, B.L., and Schurger, S.G., 2009, Andy’s Mesa Unit, San Miguel County, Colorado, in W.S. Houston, L.L. Wray, and P.G. Moreland, eds., The Paradox Basin Revisited - New Developments in Petroleum Systems and Basin Analysis: RMAG 2009 Special Publication - The Paradox Basin, p. 497-518.

Balsley, J.R., 1952, Aeromagnetic Surveying: Advances in Geophysics Volume 1 Advances in Geophysics, p. 313-349, doi: 10.1016/s0065-2687(08)60210-1.

Barbeau, D.L., 2003, A flexural model for the Paradox Basin: implications for the tectonics of the Ancestral Rocky Mountains: Basin Research, v. 15, p. 97-115, doi: 10.1046/j.13652117.2003.00194.x.

Cady, J. W., 1980, Calculation of gravity and magnetic anomalies of finite-length right polygonal prisms: Society of Exploration Geophysicists, v. 45, p. 1507-1512, doi: 10.1190/1.441045.

Case, J.E., and Joesting, H., 1972, Regional geophysical investigations in the central Colorado Plateau: Geological Survey Professional Paper, doi: 10.3133/pp736.

Cole III, S.L., DuChene, H.R., and Greenberg, N., 2009, Geology of the Double Eagle Unit, Andy’s Mesa Field, San Miguel County, Colorado, in W.S. Houston, L.L. Wray, and P.G. Moreland, eds., The Paradox Basin Revisited - New Developments in Petroleum Systems and Basin Analysis: RMAG 2009 Special Publication - The Paradox Basin, p. 519-533.

Constantino, R. R., Molina, E. C., and Souza, I. A. 2016, Study of Salt Structures from Gravity and Seismic Data in Santos Basin, Brazil: Geofisica Internacional v. 55-3, p. 199-214, doi: 10.19155/rgi20165531612. 
Cook, K.L., Nilsen, T.H., Lambert, J.F., 1971, Gravity base station network in Utah - 1967, Utah Geological and Mineralogical Survey, v. 92, doi: 10.34191/b-92.

Doelling, H.H., 2002a, Geologic Map of the Fisher Towers 7.5' Quadrangle, Grand County, Utah: Utah Geological Survey, p. 1-22, doi: ISBN 1-55791-582-2.

Doelling, H.H., 2002b, Geologic Map of the Moab and Eastern Part of the San Rafael Desert 30' X 60' Quadrangles, Grand and Emery Counties, Utah, and Mesa County, Colorado: Utah Geological Survey.

Dubiel, R.F., Huntoon, J.E., Stanesco, J.D., and Condon, S.M., 2009, Cutler Group Alluvial, Eolian and Marine Deposystems: Permian facies relations and climatic variability in the Paradox Basin, in W.S. Houston, L.L. Wray, and P.G. Moreland, eds., The Paradox Basin Revisited -New Developments in Petroleum Systems and Basin Analysis: RMAG 2009 Special Publication- The Paradox Basin, p. 265-308.

Frese, R. R. B. Von, Woo Kim, J., Bentley, C. R., 1999, Antarctic Crustal Modeling from the Spectral Correlation of Free-Air Gravity Anomalies with the Terrain, Journal of Geophysical Research: Solid Earth, vol. 104, no. B11, pp. 25275-25296., doi:10.1029/1999jb900232.

Gernigon, L., Brönner, M., Fichler, C., Løvås, L., Marello, L., and Olesen, O., 2011, Magnetic expression of salt diapir-related structures in the Nordkapp Basin, western Barents Sea: Geology, v. 39, p. 135-138, doi: 10.1130/g31431.1.

Giles, K. A., and M. G. Rowan, 2012, Concepts in halokinetic sequence deformation and stratigraphy: in G. I. Alsop, S. G. Archer, A. J. Hartley, N. T. Grant, and R. Hodgkinson, eds., Salt tectonics, sediments and prospectivity: Geological Society, London, Special 
Publications 2012, vol. 363, p. 7-31.

Giles, K. A., "The Paradox Salt Basin, Utah and Colorado: Recognition of New Types of Salt Features and Their Impact on Salt-Related Traps.” American Association of Petroleum Geologists ACE, 2-5 April 2017, Houston, Texas, Presentation.

Goydas, M.J., 1990, Provisional Geologic Map of the Fisher Valley Quadrangle, Grand County, Utah, Utah Geological Survey Open-File Report 167, 48 p

Grisi, K.C, 2018, Attributes of the Fisher Valley Megaflap and Comparison to the Gypsum Valley Megaflap, Paradox Basin, Utah and Colorado: Implications for Control on Megaflap Formation. ETD Collection for University of Texas, El Paso.

Halbouty, M.T., 1982, The Time is Now for All Explorationists to Purposefully Search for Subtle Trap: AAPG Bulletin, v. 65, doi: 10.1306/2f919e90-16ce-11d7-8645000102c1865d.

Hinze, W.J., Aiken, C., Brozena, J., Coakley, B., Dater, D., Flanagan, G., Forsberg, R., Hildenbrand, T., Keller, R.G., Kellogg, J., Kucks, R., Li, X., Mainville, A., Morin, R., Pilkington, M., Plouff, D., Ravat, D., Roman, D., Urrutia-Fucugauchi, J., Veronneau, M., Webring, M., and Winester, D., 2005, New Standards for Reducing Gravity Data: The North American Gravity Database. Geophysical, Vol. 70 NO.4 (July-August 2005); P. J25J32, 1 Table. doi:10.1190/1.1988183.

Holom, D. I., Oldow, J. S., 2007, Gravity reduction spreadsheet to calculate the Bouguer anomaly using standardized methods and constants. Geosphere, 3(2), 86. doi:10.1130/ges00060.1.

Hudec, M.R., 1995, The Onion Creek Salt Diapir: An Exposed Diapir Fall Structure In The Paradox Basin, Utah: Salt, Sediment and Hydrocarbons, doi: 10.5724/gcs.95.16.0125. 
Khatun, S., Doser, D., Imana, E., and Keller, G., 2007, Locating Faults in the Southern Mesilla Bolson, West Texas and Southern New Mexico, Using 3-D Modeling of Precision Gravity Data: Journal of Environmental \& Engineering Geophysics, v. 12, p. 149-161, doi: 10.2113/jeeg12.2.149.

Kluth, C.F., and DuChene, H.R., 2008, Late Pennsylvanian and Early Permian Structural Geology and Tectonic History of the Paradox Basin and Uncompahgre Uplift, Colorado and Utah, in W.S. Houston, L.L. Wray, and P.G. Moreland, eds., The Paradox Basin Revisited - New Developments in Petroleum Systems and Basin Analysis: RMAG 2009 Special Publication - The Paradox Basin, p. 178-197.

Langford, R., 2018, "Shoulder Formation in the Paradox Basin: A Record of Progressive Diapir Narrowing and Minibasin Expansion.” American Association of Petroleum Geologists ACE, 20-23 May 2018, Salt Lake City, Utah, Presentation.

Lankford-Bravo, D. F., "Multiple Stages of syndepositional halokinectic (?) deformation in the Permian Cutler Formation, northern margin of the Onion Creek Diapir, Paradox Basin, UT.” American Association of Petroleum Geologists ACE, 19-22 May 2019, San Antonio, TX, Poster.

Leftwich, T. E., Frese, R. R. B. Von, Potts, L. V., Kim, H. R., Roman, D. R., Patrick, T. T., Barton, M., 2005, Crustal Modeling of the North Atlantic from Spectrally Correlated Free-Air and Terrain Gravity, Journal of Geodynamics, vol. 40, no. 1, pp. 23-50., doi:10.1016/j.jog.2005.05.001.

Mancini, E. A., Parcell, W.C., Puckett, T. M, and Benson, J. D., 2003, Upper Jurassic (Oxfordian) Smackover Carbonate Petroleum System Characterization and Modeling, Mississippi 
Interior Salt Basin Area, Northeastern Gulf of Mexico, USA. Carbonates Evaporites, v. 18, no. 2, p.125-150, doi: doi.org/10.1007/BF03176234.

Mcbride, B.C, Weimer, P., Rowan, M.G., "The Effect of Allochthonous Salt on the Petroleum Systems of Northern Green Canyon and Ewing Bank (Offshore Louisiana), Northern Gulf of Mexico." AAPG Bulletin, 82, 1998, doi:10.1306/1d9bc9fd-172d-11d7$8645000102 \mathrm{c} 1865 \mathrm{~d}$.

McFarland, J. C., "Structural and stratigraphic development of a salt-diapir shoulder, Gypsum Valley, Colorado" (2016). ETD Collection for University of Texas, El Paso. AAI10118149.

Nabighian M. N., Grauch V. J. S., Hansen R. O., LaFehr T. R., Li1 Y., Peirce J. W., Phillips J. D., and Ruder M. E., 2005, The historical development of the magnetic method in exploration: Society of Exploration Geophysicists, v. 70, p. 33-61, doi: $10.1190 / 1.2133784$

Nuccio, V.F., and Condon, S.M., 1996, Burial and thermal history of the Paradox Basin, Utah and Colorado, and petroleum potential of the Middle Pennsylvanian Paradox Basin: U.S. Geological Survey Bulletin 2000-O, p. O1-O41, doi: 10.3133/b00o.

Palmer, H.C., Macdonald, W.D., Gromme, C.S., and Ellwood, B.B., 1996, Magnetic properties and emplacement of the Bishop tuff, California: Bulletin of Volcanology, v. 58, p. 101116, doi: 10.1007/s004450050129.

Rasmussen, L., and Rasmussen, D.L., 2009, Burial History Analysis of the Pennsylvanian Petroleum System in the Deep Paradox Basin Fold and Fault Belt, Colorado and Utah: The 
Paradox Basin Revisited- New Developments in Petroleum Systems and Basin Analysis: RMAG Special Publication, p. 24-94.

Rowan, M. G., Peel, F. j., Vendeville, B. C., Gaullier, V., 2012, Salt Tectonics at Passive Margin: Geology Versus Models - Discussion, Marine and Petroleum Geology, 37 (2012), p. 184194, doi:10.1016/j.marpetgeo.2012.04.007.

Rowan, M.G., Giles, K.A., Hearon IV, T.E. and Fiduk, J.C., 2016, Megaflaps adjacent to salt diapirs: AAPG Bulletin, vol. 100, no. 11, p.1723-1747.

Schamel, S., 2009, Shale Gas Potential of the Paradox Basin, Colorado and Utah, in W.S. Houston, L.L. Wray, and P.G. Moreland, eds., The Paradox Basin Revisited - New Developments in Petroleum Systems and Basin Analysis: RMAG 2009 Special Publication - The Paradox Basin, p. 568-603.

Talwani, M., Worzel L. J., and Landisman, M, 1959, Rapid Gravity Computations for TwoDimensional Bodies with Application to the Mendocino Submarine Fracture Zone: Journal of Geophysical Research, v. 64, p. 49-59, doi: 10.1029/JZ064i001p00049.

Trudgill, B.D., 2011, Evolution of salt structures in the northern Paradox Basin: controls on evaporite deposition, salt wall growth and supra-salt stratigraphic architecture: Basin Research, v. 23, p. 208-238, doi: 10.1111/j.1365-2117.2010.00478.x.

Trudgill, B.D., and Arbuckle, W.C., 2009, Reservoir characterization of clastic cycle sequences in the Paradox Formation of the Hermosa Group, Paradox Basin, Utah: UTAH DEPARTMENT OF NATURAL RESOURCES, p. 1-95, doi: 10.34191/ofr-543. 
Whidden, Katherine J, 2012, Assessment of Undiscovered Oil and Gas Resources in the Paradox Basin Province, Utah, Colorado, New Mexico, and Arizona, 2011. USGS Fact Sheet, 2012, doi:10.3133/fs20123031.

Whidden, Katherine J., Paul G. Lillis, Lawrence O. Anna, Krystal M. Pearson, and Russell F. Dubiel., 2014. Geology and total petroleum systems of the Paradox Basin, Utah, Colorado, New Mexico, and Arizona. The Mountain Geologist, v. 51, no. 2, p.119-138. 


\section{VITA}

Julia Michelle Astromovich was awarded a Bachelor's of Science from Lake Superior State University in 2018. There she completed research as an undergraduate in paleomagnetism. This study took place over three years and focused on the southern Sierra Nevada Mountains and the rotation of the volcanic diapirs there. She has experience teaching field-based and online only courses as a teaching assistant at UTEP. These courses included geoscience processes, geophysics field camp, geology field camp, and principles of earth sciences lab. Julia also has oil and gas industry experience from her time as a geophysicist intern at BP. This internship took place over the summer of 2020 and consisted of an 8-week entirely virtual work environment. Julia hopes to work in oil and gas after obtaining her Master's degree in geophysics.

Contact Information: juliaastromovich@gmail.com 